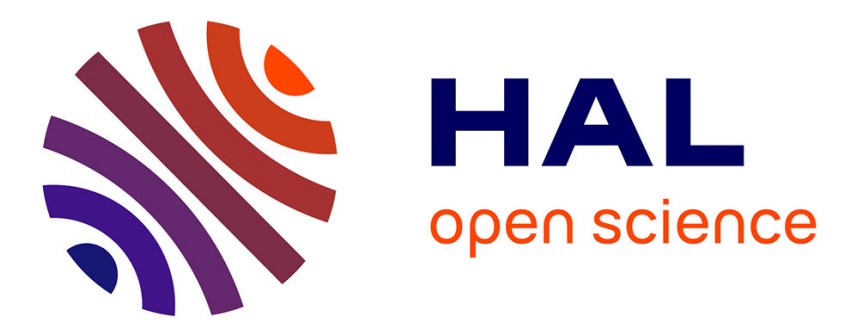

\title{
Pliocene suids from Musaitu and Dermenji, Moldova: implications for understanding the origin of African Kolpochoerus Van Hoepen \& Van Hoepen, 1932
}

Martin Pickford, Théodor Obada

\section{- To cite this version:}

Martin Pickford, Théodor Obada. Pliocene suids from Musaitu and Dermenji, Moldova: implications for understanding the origin of African Kolpochoerus Van Hoepen \& Van Hoepen, 1932. Geodiversitas, 2016, 38 (1), pp.99-134. 10.5252/g2016n1a5 . hal-01306766

\section{HAL Id: hal-01306766 \\ https://hal.sorbonne-universite.fr/hal-01306766}

Submitted on 25 Apr 2016

HAL is a multi-disciplinary open access archive for the deposit and dissemination of scientific research documents, whether they are published or not. The documents may come from teaching and research institutions in France or abroad, or from public or private research centers.
L'archive ouverte pluridisciplinaire HAL, est destinée au dépôt et à la diffusion de documents scientifiques de niveau recherche, publiés ou non, émanant des établissements d'enseignement et de recherche français ou étrangers, des laboratoires publics ou privés.

\section{(c)(1)}

Distributed under a Creative Commons Attribution| 4.0 International License 


\section{Pliocene suids from Musaitu and Dermenji, Moldova: implications for understanding the origin of African Kolpochoerus Van Hoepen \& Van Hoepen, 1932}

Martin PICKFORD

CR2P (MNHN, CNRS, UPMC, Sorbonne-Université), Département Histoire de la Terre, Muséum national d'Histoire naturelle, case postale 38, 57 rue Cuvier, F-75231 Paris cedex 05 (France)

pickford@mnhn.fr

Théodor OBADA

Institute of Zoology, Academy of Sciences of Moldova, Str. Academiei 1, 2028, Chisinau (Moldova) theodorobada@gmail.com

Published on 25 March 2016

Pickford M. \& Obada T. 2016. - Pliocene suids from Musaitu and Dermenji, Moldova: implications for understanding the origin of African Kolpochoerus Van Hoepen \& Van Hoepen, 1932. Geodiversitas 38 (1): 99-134. http://dx.doi. org/10.5252/g2016n1a5

\section{ABSTRACT}

Early Pliocene suids of Europe are generally rare and poorly preserved, but some exceptional fossils have been found at Roussillon, France, Villafranca d'Asti, Italy, and Kvabebi, Georgia. We here describe and interpret an almost complete skull of a small suid from Musaitu and a mandible fragment from Dermenji, Moldova, which add precious information to the data base concerning these small European Pliocene suids, here attributed to Dasychoerus arvernensis (Croizet \& Jobert, 1828). The Moldovan fossils provide an important biogeographic link between the Western European and Asian Plio-Pleistocene suines. The Musaitu skull, in particular, shows the elongated snout, enlarged canine flanges, pneumatised zygomatic arch and low slung incisor row characteristic of the genus Dasychoerus Gray, 1873. This species is important because it represents the group from which the African Kolpochoerus Van Hoepen \& Van Hoepen, 1932 lineage probably emerged. The latter group is useful for biochronology because, having arrived in Africa, where it has been called Kolpochoerus deheinzelini Brunet \& White, 2001 (in fact a junior synonym of Dasychoerus arvernensis) it evolved

KEY WORDS Moldova,

Pliocene,

Suidae,

Dasychoerus,

Kolpochoerus,

Palaeobiogeography. rapidly in dimensions and dental morphology. During the Pliocene the genus Dasychoerus, already adapted to tropical and sub-tropical climates, was widespread in mid-latitude Eurasia and Africa, but when much of mid-latitude Eurasia became boreal during the Plio-Pleistocene, the range of Dasychoerus shrank equatorwards, giving way to boreally adapted Sus scrofa Linnaeus, 1758 over much of its former territory, leaving a disjunct distribution of its descendants in Africa (Hylochoerus Thomas, 1904, possibly Potamochoerus Gray, 1854) and the tropical islands of the Far East (Dasychoerus). 


MOTS CLÉS
Moldavie,
Pliocène,
Suidae,
Dasychoerus,
Kolpochoerus,
evolution,
Paléobiogéographie.

MOTS CLÉS

Moldavie,

Suidae,

Kolpochoerus,

évolution,

Paléobiogéographie.

\begin{abstract}
RÉSUMÉ
Les Suidés pliocènes de Musaitu et Dermenji, Moldavie: implications pour la compréhension de l'origine du Kolpochoerus Van Hoepen \& Van Hoepen, 1932 d'Afrique.

Les suidés du Pliocène inférieur d'Europe sont généralement rares et mal préservés, néanmoins des fossiles exceptionnels ont été retrouvés à Roussillon en France, à Villafranca d'Asti en Italie et à Kvabebi en Géorgie. Nous décrivons et interprétons un crâne presque complet d'un petit suidé de Musaitu et un fragment de mandibule de Dermenji en Moldavie, attribués à Dasychoerus arvernensis (Croizet \& Jobert, 1828). Ces fossiles ajoutent des informations précieuses à la connaissance des petits suidés européens pliocènes. Les fossiles moldaves constituent un lien biogéographique important entre les suinés plio-pléistocènes de l'Europe occidentale et ceux de l'Asie. En particulier, le crâne de Musaitu présente les caractéristiques du genre Dasychoerus Gray, 1873: un museau allongé, des canines au rebord évasé, une arcade zygomatique pneumatisée et une rangée incisive basse. Cette espèce est importante car elle représente le groupe duquel la lignée africaine Kolpochoerus Van Hoepen \& Van Hoepen, 1932 a probablement émergée. Ce dernier groupe est utile en biochronologie, parce qu'étant arrivé en Afrique où il a été nommé Kolpochoerus deheinzelini Brunet \& White, 2001 (en fait un synonyme de Dasychoerus arvernensis) ses dimensions et sa morphologie dentaire ont rapidement évolué. Au cours du Pliocène, le genre Dasychoerus, déjà adapté aux climats tropicaux et subtropicaux, était largement répandu aux latitudes moyennes d'Eurasie et d'Afrique, mais quand les latitudes moyennes eurasiennes devinrent boréales durant le Plio-Pléistocène, son extension géographique s'est réduite vers l'équateur, laissant la place à Sus scrofa Linnaeus, 1758 sur une grande partie de son ancien territoire et conduisant à une répartition disjointe de ses descendants en Afrique (Hylochoerus Thomas, 1904, probablement Potamochoerus Gray, 1854) et dans les îles tropicales (Dasychoerus).
\end{abstract}

\section{INTRODUCTION}

For well over a century, the origins of the African Plio-Pleistocene suid lineages remained obscure, with various authors either proposing that they emerged from a "hypothetical Sus-like ancestor" (Cooke \& Wilkinson 1978) or simply not attempting to propose an ancestor, a history summarised by Pickford (2012, 2013a). Recently, Pickford (2012) observed that the most primitive described species of Kolpochoerus Van Hoepen \& Van Hoepen, 1932 (K. deheinzelini Brunet \& White, 2001) is morphometrically so close to the type material of Dasychoerus arvernensis (Croizet \& Jobert, 1828) and other European specimens attributed to this taxon (and to Sus minor Depéret, 1890, another synonym of Dasychoerus arvernensis), that the African form should be transferred to this species. The species Kolpochoerus millensis Haile-Selassie \& Simpson, 2012, is closely related to Dasychoerus arvernensis, the morphology and dimensions of its third molars overlapping those of $D$. arvernensis, but with several larger individuals. These suid species share a number of other characters including thickened mandibular bodies, low slung lower incisors, pneumatised zygomatic arches and well developed supracanine flanges (at least in males) among others. The somewhat larger species Kolpochoerus afarensis Cooke, 1978 is likely a continuation of this trend towards increase in body dimensions, although some authors see in this species the origin of the Potamochoerus lineage (Bishop 2010; Souron et al. 2013).

Having arrived in Africa by dispersal from Eurasia, Dasychoerus natrunensis Pickford, 2012, and/or Dasychoerus arvernensis underwent rapid evolution in dimensions to give rise to Kolpochoerus millensis Haile-Selassie \& Simpson, 2012, and Kolpochoerus afarensis Cooke, 1978, and the lineage then ex- perienced rapid morphological and dimensionsal evolution of the skull and dentition to give rise to several taxa including Kolpochoerus olduvaiensis (Leakey, 1942), Kolpochoerus majus (Hopwood, 1934), Kolpochoerus phacochoeroides (Thomas, 1884), Kolpochoerus paiceae (Broom, 1931), Kolpochoerus heseloni (Leakey, 1943), Kolpochoerus cookei Brunet \& White, 2001, and Kolpochoerus phillipi Souron, Boisserie \& White, 2013 some of which developed high crowned cheek teeth. The extant genus Hylochoerus Thomas, 1904 (the Giant Forest Hog) probably descended from this same immigrant group.

Having diversified in Africa some kolpochoeres returned to the Middle East and Asia including Kolpochoerus evronensis (Haas, 1970) to Israel and Kolpochoerus falconeri (Lydekker, 1884) and Kolpochoerus cautleyi (Pilgrim, 1926) to IndoPakistan. The status of Sus lydekkeri Zdansky, 1928 (Young 1932; Dong 2008) from Choukoutien, China, needs further investigation, as its third molars and some skull characters (supra-canine flange) show resemblances to those of some species of Kolpochoerus, such as K. phacochoeroides (Thomas, 1884) K. majus (Hopwood, 1934), and K. phillipi.

Thus, any increase in knowledge about the Eurasian group from which the African Kolpochoerus, could have evolved, is to be welcomed.

During the Pliocene and early Pleistocene, within the confines of Europe, Dasychoerus arvernensis underwent evolution notably in dimensions, culminating in the large suine Dasychoerus strozzii (Meneghini, 1862) (Forsyth-Major 1881).

It is not beyond the realms of possibility that Dasychoerus Gray, 1873, could be the group from which the genus Potamochoerus Gray, 1854, descended - fossils of Kolpochoerus and Dasychoerus have on occasion been attributed to Potamochoerus (Cooke 1978; Arribas \& Garrido 2008; Bishop 2010). Souron 
et al. (2013) indicated that Potamochoerus was the sister group of Kolpochoerus + Hylochoerus, with Sus scrofa Linnaeus, 1758 more distantly related. These authors classified the species K. afarensis in Potamochoerus, a suggestion that echoes back to the identifications of Cooke (1978) and Bishop (2010).

In Asia, a similar scenario played out, with small species of Dasychoerus, close in dimensions and morphology to Dasychoerus arvernensis, evolving into larger species such as Dasychoerus macrognathus Dubois, 1908, and Dasychoerus brachygnathus Dubois, 1908 (Hardjasasmita 1987) and the extant species Dasychoerus verrucosus (Müller \& Schlegel, 1845) and Dasychoerus celebensis (Müller \& Schlegel, 1845) (Pickford 2013a-c). The strange suid from the Celebes; Celebochoerus heekereni Hooijer, 1948 (Hooijer 1954, 1969, 1972; Suyono 2009) could well be a descendent of this same small Dasychoerus arvernensis as could some of the Chinese Plio-Pleistocene suids including "Sus" australis Han, 1987 (Pickford 2013b).

In the Siwaliks of Indo-Pakistan, there are several Pliocene species of suines which probably also belong to Dasychoerus arvernensis, including Sus hysudricus Falconer \& Cautley, 1846, (not to be confused with Propotamochoerus hysudricus (Stehlin, 1899-1900)), Dicoryphochoerus durandi Pilgrim, 1926, and Sus bakeri Pilgrim, 1926.

In contrast, the origin of the species "Sus" provincialis Blainville, 1847 (Gervais 1850) probably predated the radiative process of Dasychoerus-Kolpochoerus, and it may have given rise to what in Africa are known as metridiochoeres and phacochoeres (Pickford 2012, 2013d).

\section{MATERIAL AND METHODS}

Dental nomenclature is based on the approaches of Hünermann (1968) and Pickford (1988, 2013d). Tooth types are abbreviated to single letters of the alphabet ( $\mathrm{i}$ - incisor, $\mathrm{c}-\mathrm{ca}$ nine, $\mathrm{p}$ - premolar, $\mathrm{m}$ - molar). Upper teeth are identified by capital letters (I, C, P, M) followed by a number representing the meristic position, followed by a forward slash representing the occlusal surface (i.e. the number is above the occlusal surface, therefore an upper tooth eg M1/ - first upper molar). Lower teeth are identified by lower case letters (i, c, p, m) followed by the forward slash and then by the number (ie the number is beneath the occlusal surface, therefore a lower tooth, e.g., p/3 - third lower premolar). Deciduous cheek teeth are identified by the letter "d" or "D". Osteological terms are from Sisson \& Grossman (1953) and facial musculature terminology is from Ewer (1958).

Place names in Moldova have been spelled in various ways in relation to the history of this part of what used to be called Central Bessarabia (Bessarabie Meridionale). Transliterations of the names from the Cyrillic vary from author to author, in large measure reflecting the mother tongue of the person doing the transliteration. We here use the original spellings of place names based on Romanian, but provide recent equivalents encountered in the literature (see Fig. 1): Carbolia-Karboliya; Chisinau-Kishinev; Ialpug-Yalpug; Cogâlnic-Kogilnic; Cuchiurgan-Kuchurgan; Nistru-Dneister.

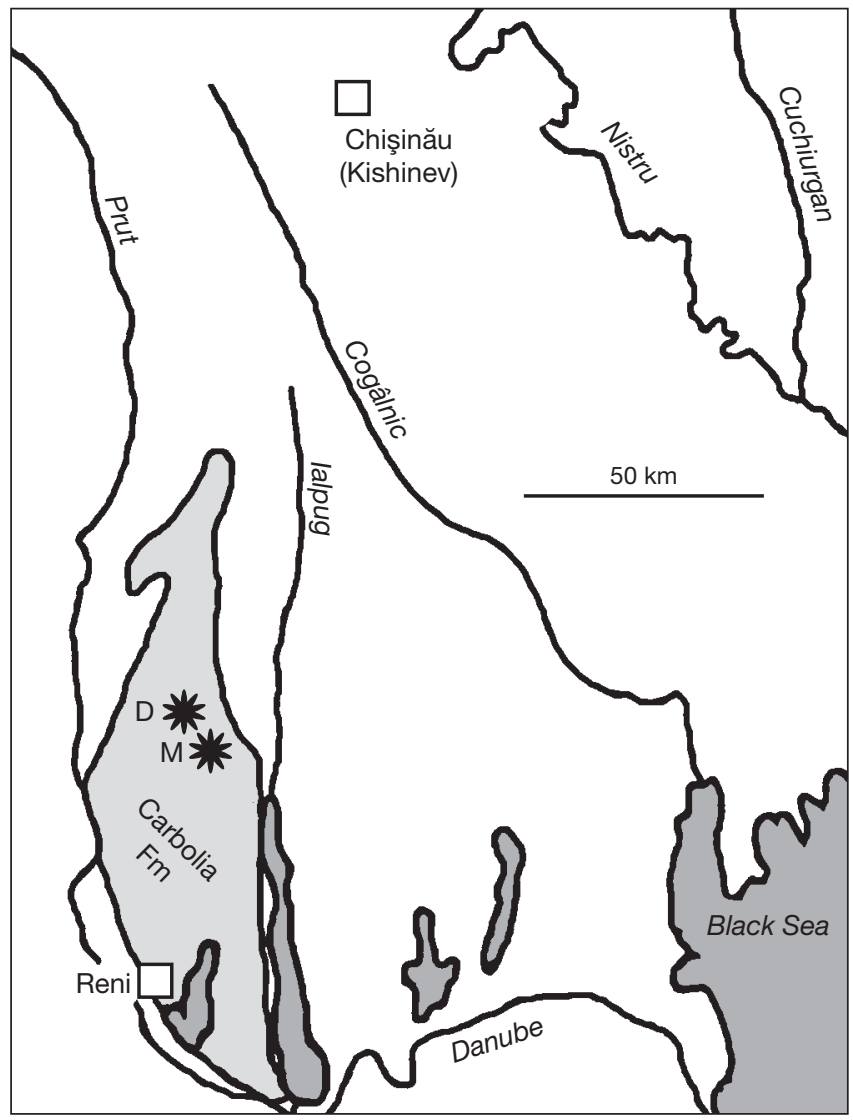

FIG. 1. - Map of southwestern Moldova and part of Ukraine, showing the distribution of the fluviatile Carbolia Formation and the fossiliferous sites of Dermenji (D) and Musaitu (M). Map modified from Pevzner et al. 1996.

\section{ABBREVIATIONS}

The fossils examined during this study are housed at the following institutions or collections.

BEL Belohdelie, Ethiopia;

BGSK British Geological Survey, Keyworth;

CCECL Centre de Conservation et d'Études des Collections, Lyon; FSL Faculty of Science, Lyon;

IM Ipswich Museum;

KB Kossom Bougoudi, Chad;

MC Mine Capeni;

MCFFMIZASM Musée des Complexes faunistiques fossiles de Moldova, Institut de Zoologie, Académie des Sciences de Moldavie;

MCNM Museo National de Ciencias Naturales, Madrid;

MGPUT Museum of Geology and Palaeontology, University of Turin;

MIL Milia Museum;

MNHN Muséum national d'Histoire naturelle, Paris;

MPV Museum Palaeontology Valencia;

MSG Museum Sf. Gheorghe;

NHMB Naturhistorisches Museum, Basel;

NHMUK Natural History Museum, United Kingdom, London;

NME National Museum of Ethiopia, Addis Ababa;

NMENHM National Museum of Ethnography and Natural History of Moldova;

NWHCM Norwich Castle Museum;

OCO Orrorin Community Organisation;

PIMUZ Palaeontology Institute Museum, University of Zürich;

RMNH Rijksmusem van Natuurlijke Historie, Leiden;

YORYM York, Yorkshire Museum. 


\section{GEOLOGICAL CONTEXT}

The Musaitu and Dermenji fossil localities occur within the fluviatile Carbolia Formation of southwestern Moldova (Fig. 1). The Musaitu deposits were first mentioned by Khomenko (1914) who recorded the presence of the suid ?Sus provincialis. The suid skull described herein was collected by the late Aleksandru Lungu, well known vertebrate palaeontologist based at the Tiraspol State University, Kishinev (Lungu \& Rzebik-Kowalska 2011). Written on the palate are the words "Potamochoerus provincialis Gervais", and "Musaitu, sr. Pliocene" (transliteration of the Cyrillic script).

The Musaitu skull is dark brown and has pale rusty carbonate concretions stuck to it, notably on the front of the palate in the incisive region and partly obscuring the left $\mathrm{M} 3$ / and left palatine bone. The nasal cavity is full of the same type of carbonate sediment. These preservation charactersitics indicate the likelihood that the fossil came from the basal beds of the Carbolia Formation (also spelled Karboliya) which comprise red weathered loam endowed with numerous carbonate concretions (Khubca 1982; Nadachowski et al. 2006) overlying Pontian sands.

Aleksandrova (1989) correlated the older of the Musaitu faunal elements to the base of MN 15, being equivalent to part " $A$ " of the fourfold subdivision of the Moldavian Faunal Assemblage (Complex). Vangengeim et al. (1995, 1998) correlated the site of Musaitu to MN 15 (Musaitu 5 at c. $3.8 \mathrm{Ma}$, Musaitu 7 c. $3.6 \mathrm{Ma}$ ) on the basis of the fauna (Dicerorhinus sp., Paracamelus alexejevi Khavesson, 1950, ?Ioribos sp.) and the small mammals. Pevzner et al. (1996) listed two levels Musaitu 5 and Musaitu 7 (respectively 5 and $7 \mathrm{~km}$ from Musaitu Village), the former correlated to the base of MN 15, the latter near the top. The age range calculated by these authors for Musaitu was 5-3.8 (+ 0.05-0.04) Ma. Pevzner et al. (2001) positioned Musaitu 5 at 4.2 Ma. Vangengeim et al. (2005) put Musaitu 5 at 4.1 Ma. These age estimates are not contradicted by the palaeomagnetic correlations proposed by the same authors.

Nadachowski et al. (2006) listed faunal contents from different levels within the 45-metre thick post-Pontian beds at Musaitu. The lower parts correlating to the Moldavian Mammal Complex yielded Promimomys moldavicus Kormos, 1932, Promimomys stehlini Kormos, 1931, Proochotona eximia Khomenko, 1914, Proochotona gigas Argyropulo \& Pidoplitshka, 1939, Alilepus cf. lascarevi, and the lowermost parts yielded Pliomys kowalskii Shewtschenko, 1965, Hipparion sp., Paracamelus sp. Stephanorhinus sp., Talpa minor Freudenberg, 1914, Spalacidae Gray, 1821 and Cricetidae Fischer, 1817 (Khubca 1982). The uppermost part of the outcrops yielded Leporidae Fischer, 1817, Ochotonidae Thomas, 1897, Castoridae Hemprich, 1820, Nannospalax sp., Pliomys kowalskii and Promimomys moldavicus. Large mammals from the Musaitu badlands comprise Vulpes sp., Mammut borsoni (Hays, 1834), Anancus ex gr. arvernensis (Croizet \& Jobert, 1828), Hipparion sp., Stephanorhinus megarhinus De Christol, 1835, Paracamelus alexejevi Khavesson, 1950, Cervinae Goldfuss, 1820, and Parabos boodon Gervais, 1853. The very highest levels of the deposits yielded Talpa sp., Pliopetaurista moldaviensis Baranova \& Konkova, 1974, Apodemus dominans Kretzoi, 1959, Pliomys sp., and Cervinae.

\section{SYSTEMATIC PALAEONTOLOGY}

\author{
Family SUIDAE Gray, 1821
}

Genus Dasychoerus Gray, 1873

GENERIC DIAGNOSIS. - Suinae with verrucosic male lower canines, relatively narrow parietal region of the skull slightly convex transversely; gently undulating dorsal skull profile; widely diverging zygomatic arches tending to be broader in the middle than at the rear, zygoma inflated; laterally expanded nasals; large and rugose supra-canine flange (in males, more gracile in females), elongated rostrum; thickened mandibular body (pachygnathy Arambourg 1947) (modified and extended from descriptions in Azzaroli 1954 and Berdondini 1992).

TYPE SPECIES. - Sus verrucosus Müller \& Schlegel, 1845.

\section{Dasychoerus arvernensis (Croizet \& Jobert, 1828)}

Aper arvernensis Croizet \& Jobert, 1828: 157-160, pl. XIII, figs 3-5. Sus provincialis var. minor Depéret, 1890: 84-88, pl. V, figs 12-14.

Sus minor - Tobien 1951: 79-83; 1952: 191; Hünermann 1971: 213-222.

Sus arvernensis arvernensis - Guérin \& Faure 1985: 22; Guérin et al. 1998: 442.

Sus arvernensis minor - Guérin \& Faure 1985: 443-447.

For additional synonymy of the species see Fejfar (1964) and Hünermann (1971).

Type locality. — Les Étouaires, Perrier, France.

AgE OF TYPE LOCALITY. - MN 16, Lower Villafranchian (3.93.4 Ma, Bout, 1968, 3.6-2.4 Ma, Steininger et al. 1990).

HolotyPE. — Specimen MNHN.F.PET2005 labelled "Étouaires", comprising associated juvenile left maxilla containing D2/-D4/ and $\mathrm{M} 1 /$ and a left mandible fragment and symphysis containing $\mathrm{d} / 2$ $\mathrm{d} / 4$ and $\mathrm{m} / 1$ in occlusion on both sides, and the germ of the left $\mathrm{m} / 2$ and $\mathrm{p} / 4$ in crypto (illustrated in mirror image by Croizet $\&$ Jobert [1828], and Blainville [1847] which has caused confusion about which side the specimens came from [Guérin \& Tsoukala 2013]). The symphyseal fragment which fits onto the left mandible contains parts of the left and right canines in situ (verrucosic male morphology) and the left i/ 2 in crypt (partly exposed by damage to the symphysis). The right mandible containing the $\mathrm{d} / 2-\mathrm{d} / 4$ and $\mathrm{m} / 1$ belongs to the same individual (Figs 2-6).

\section{DiAGNOSIS}

Small species of Dasychoerus, length M1/, 14.2-18 mm; length M2/, 18.5-22 mm; length M3/, 24.6-29.4 mm; length $\mathrm{m} / 1,14.7-18 \mathrm{~mm}$; length $\mathrm{m} / 2,18-24 \mathrm{~mm}$; length $\mathrm{m} / 3,28.3-33.3 \mathrm{~mm}$.

Note on nomenclature and lectotypes of Sus minor Guérin \& Faure (1985), Guérin et al. (1998) and Guérin \& Tsoukala (2013) retained two subspecies Sus arvernensis arvernensis (Croizet \& Jobert, 1828) and Sus arvernensis minor (Depéret, 1890) for these small Plio-Pleistocene European suids. Guérin et al. (1998) separated these two 

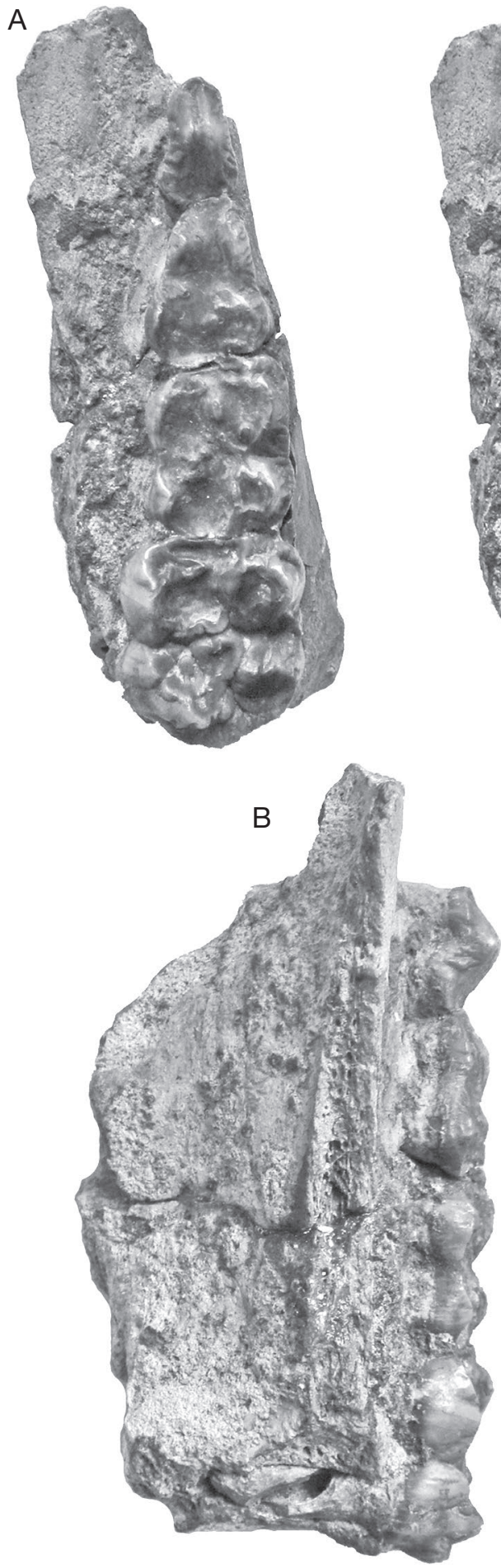
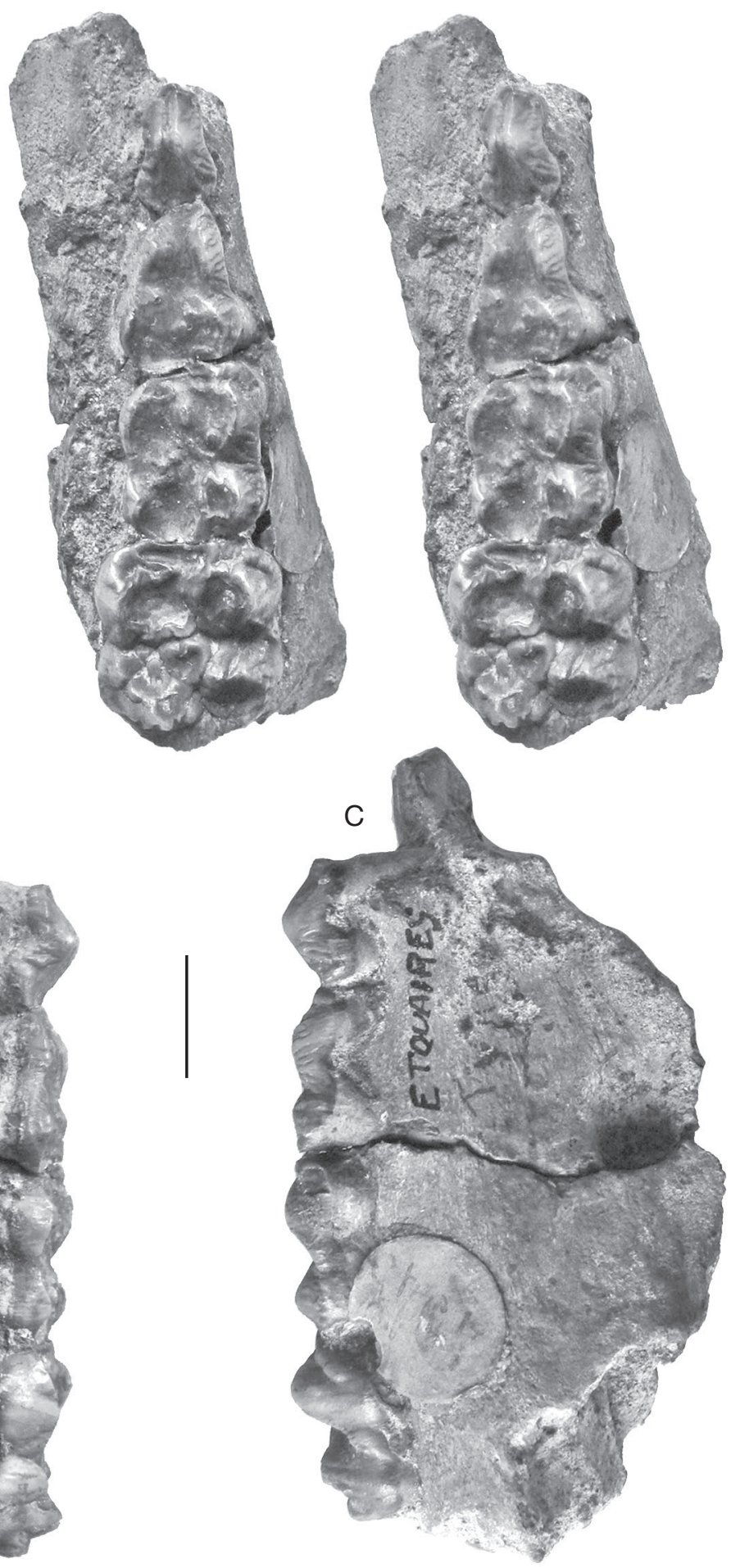

FIG. 2. - Left maxilla containing D2/-D4/ and M1/, part of the holotype of Dasychoerus arvernensis (Croizet \& Jobert, 1828), from Les Étouaires, Perrier, France (MNHN.F.PET2005, specimen labelled "Étouaires"): A, stereo triplet of the occlusal view; B, lingual view; C, buccal view. Scale bar: 10 mm.

subspecies on the basis of the smaller dimensions of Sus arvernensis minor, and its relatively long premolars, narrower molars of simpler construction with fewer accessory tubercles. However, our own analysis of the dimensions and morphology of the teeth from the two type localities, Les Étouaires and Roussillon indicate significant morphometric overlap between the two subspecies. In this study, we therefore treat all the material as a single unit at the species level, rather than continue to deal with two subspecies.

Azzaroli $(1954,1975)$ considered that Sus arvernensis was a "nomen dubium", and wrote that it could possibly be a synonym of Sus minor, in which case Sus arvernensis would be the valid name. Hünermann (1971) considered the name Sus arvernensis to be invalid due to the incomplete preservation of the type specimen 


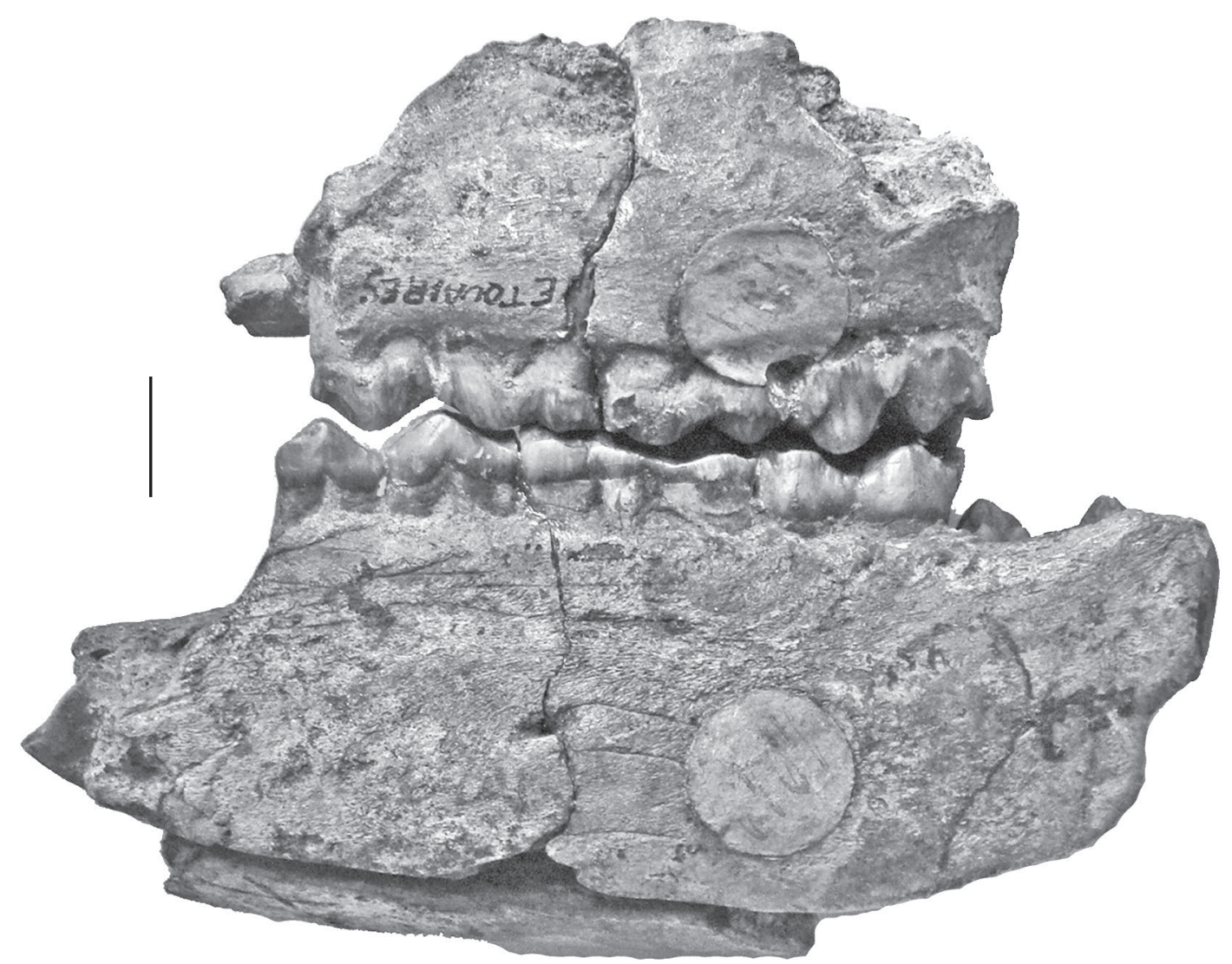

FIG. 3. - Buccal view of left maxilla and mandible containing mixed dentitions in occlusal relationship, parts of the holotype of Dasychoerus arvernensis (Croizet \& Jobert, 1828) from Les Étouaires, Perrier, France (MNHN.F.PET2005, specimen labelled "Étouaires"), figured in reverse by these authors and by Blainville (1847). Scale bar: $10 \mathrm{~mm}$.

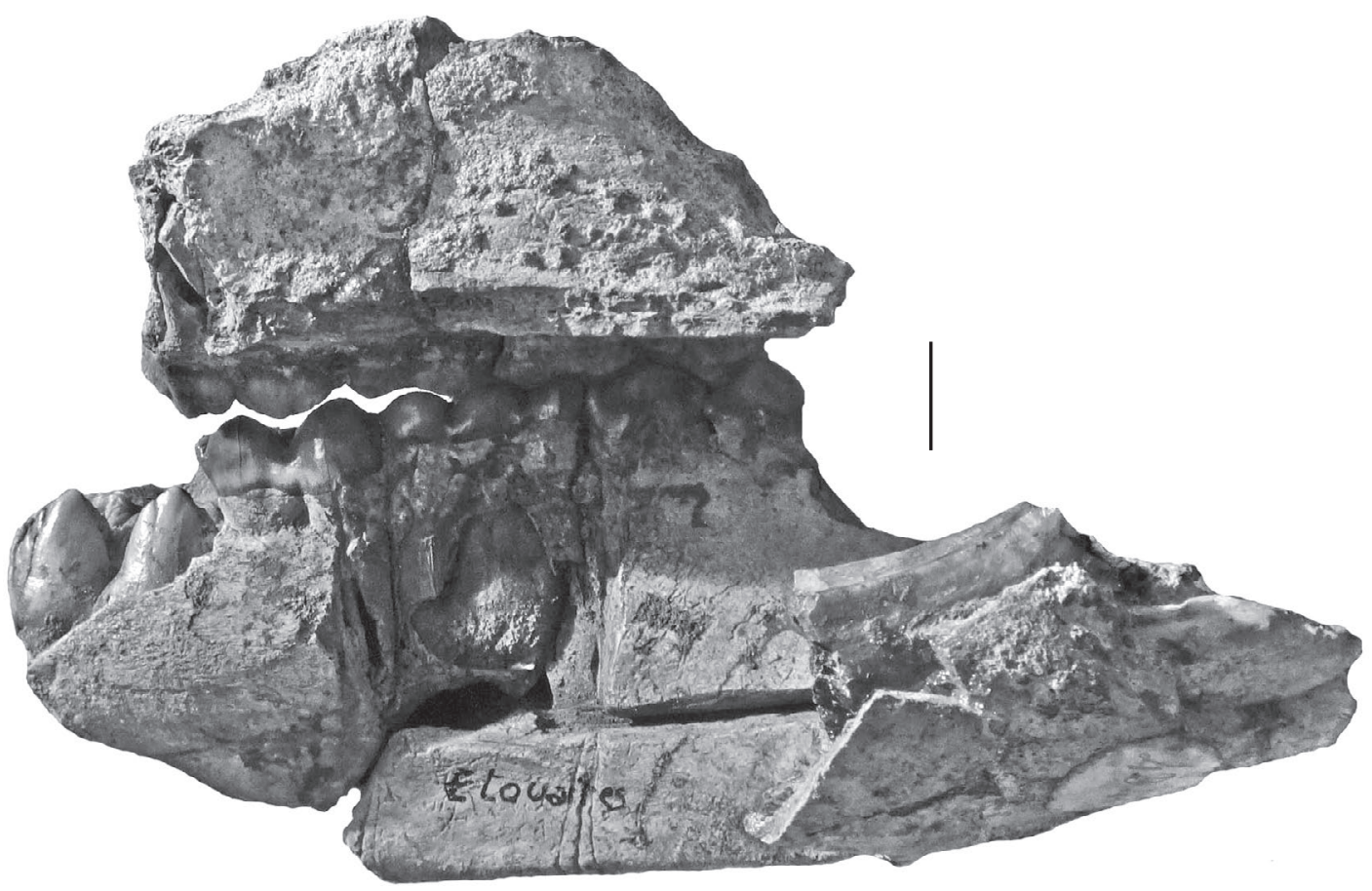

FIG. 4. - Holotype of Dasychoerus arvernensis (Croizet \& Jobert, 1828) from Les Étouaires, Perrier, France (MNHN.F.PET2005, specimen labelled "Étouaires"), viewed from the lingual side with the left maxilla, mandibular symphysis and left mandible articulated in occlusal relationship. The bone beneath the $\mathrm{d} / 4 \mathrm{has}$ been cut away to expose the $\mathrm{p} / 4$. Note also the verrucosic male canines, and the forward sloping incisors, located well beneath the level of the occlusal surface of the cheek teeth. Scale bar: $10 \mathrm{~mm}$. 

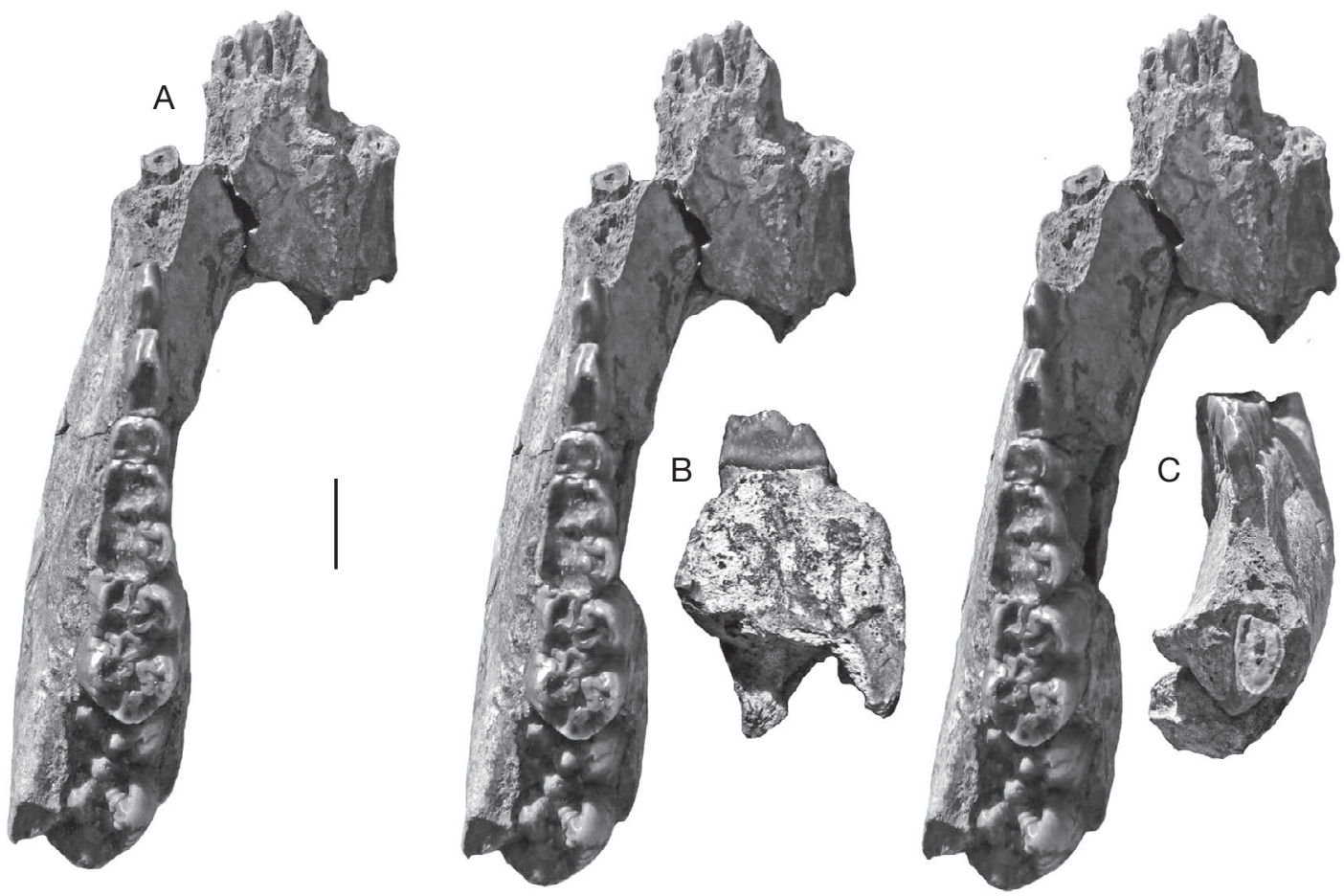

FIG. 5. - Left mandible and symphysis of the holotype of Dasychoerus arvernensis (Croizet \& Jobert, 1828) from Les Étouaires, Perrier, France (MNHN.F.PET2005, specimen labelled "Étouaires"): A, stereo triplet of the occlusal view; B, view of the rear of the right mandible behind the $\mathrm{m} / 1$ to show the thickened mandibular ramus, expressed already in this juvenile individual; $\mathbf{C}$, anterior view of left mandible to show verrucosic section of the male canine. Scale bar: 10 mm.
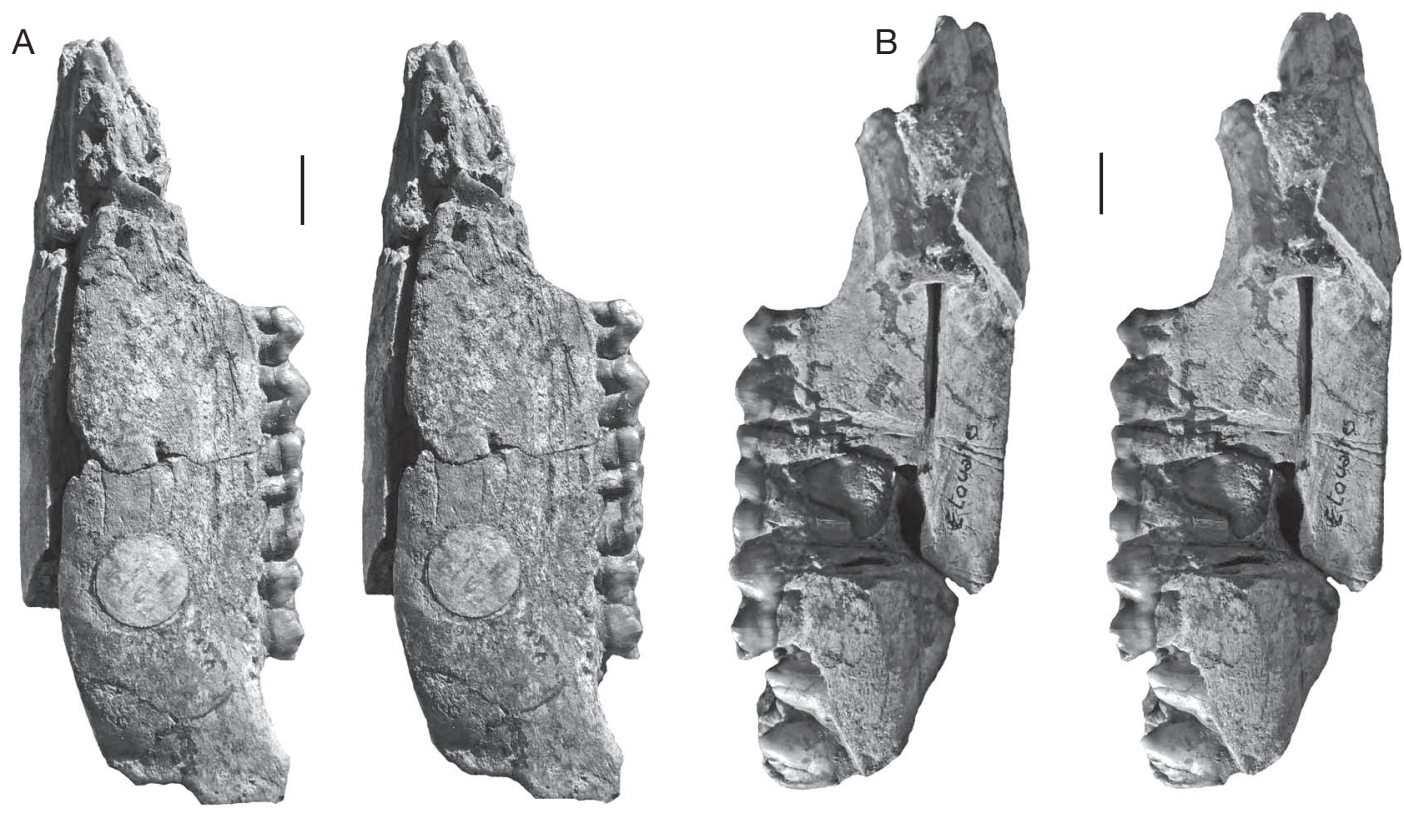

FIG. 6. - Left mandible of the holotype of Dasychoerus arvernensis (Croizet \& Jobert, 1828) from les Étouaires, Perrier, France (MNHN.F.PET2005, specimen labelled "Étouaires"): A, stereo buccal view; B, stereo lingual view. Note the very low incisors relative to the cheek tooth occlusal surface. Scale bars: $10 \mathrm{~mm}$.

(he agreed that Sus arvernensis and Sus minor were synonyms, but opted to support Sus minor even though this goes against the rule of priority). However, the type specimen of the former species is one of the more informative fossil suid specimens described, comprising associated upper and lower jaws, with well preserved elements of the deciduous and permanent cheek dentition, plus parts of both lower canines, and is thus more informative than the lectotype of Sus minor (CCECL Pp 195) which comprises a mandible fragment with $\mathrm{p} / 2-\mathrm{m} / 2$.

There is an unusual situation concerning the type specimen of Sus minor which has caused confusion to the extent that different specimens have been used by different authors as reference specimens. Four separate fossils have been proposed either as lectotypes or as syntypes. Azzaroli 

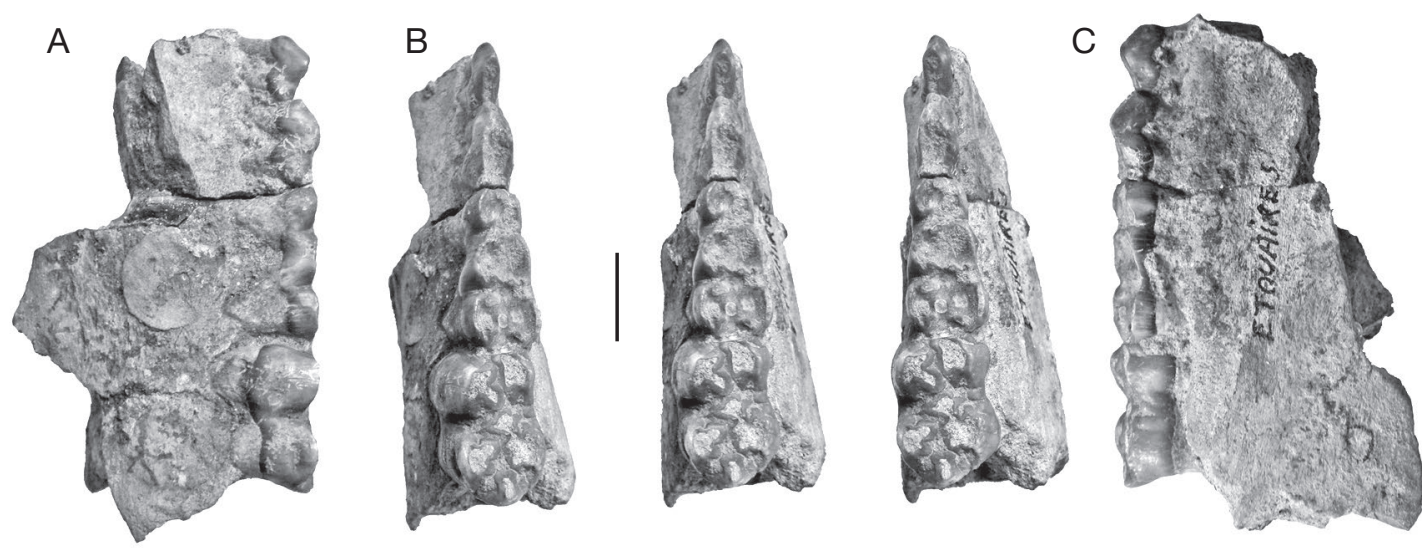

FIG. 7. - Right mandible containing d/2-m/1 of Dasychoerus arvernensis (Croizet \& Jobert, 1828) from Les Étouaires, part of the holotype (http://coldb.mnhn. fr/CatalogNumber/MNHN/F/PET2005, specimen labelled "Étouaires"): A, lingual view; B, stereo triplet of the occlusal view; C, buccal view. Scale bar: 10 mm

(1954: 58 and caption to pl. 1; fig. 6a, b) employed the term "lectotype" for the left mandible figured by Depéret (1890: pl. V, fig. 13). This is the earliest nomination of a type specimen for Sus minor and thus is the valid one. It is the specimen comprising a left mandible with unerupted (but mechanically exposed) $\mathrm{p} / 2-\mathrm{p} / 4$ and $\mathrm{m} / 1-\mathrm{m} / 2$ in occlusion, curated at the CCECL under number Pp 195. Azzaroli (1975) reiterated the nomination but made an erroneous reference (erroneous citation of figure as Azzaroli 1954: pl. V, fig. 11, 11a).

Fejfar (1964) seemingly unaware of Azzaroli's (1954) prior selection of a lectotype, nominated a different specimen as lectotype, a left lower jaw containing $\mathrm{m} / 2$ and $\mathrm{m} / 3$ in situ, according to him figured by Depéret (1890: 85, 86, pl. V, fig. 12). However, figure 12 on the cited plate is an image of a left $\mathrm{M} 3 /$, the mandible with two molars being figure 14 of the same plate.

Guérin et al. (1998) wrote that the syntypes (sic) of Sus minor consist of "an almost complete palate and a last upper molar”. These specimens from Roussillon, which comprise a left maxilla with the cheek dentition running from $\mathrm{P} 3 /-\mathrm{M} 3 /$, and an isolated $\mathrm{M} 3 /$, the former of which was attributed in the first instance to Sus arvernensis by Depéret (1885: pl. V, fig. 1).

Thus various authors have employed four different specimens to typify Sus minor, and this has undoubtedly caused some fluidity in the interpretations that flowed from the choice of type material. The first nominated, and therefore the valid lectotype of Sus minor is the mandible nominated by Azzaroli (1954) "CCECL Pp 195".

In order to clarify the situation, the type materials of Dasychoerus arvernensis (Figs 2-7) and "Sus" minor (Fig. 8) are illustrated. The holotype of Dasychoerus arvernensis possesses the following teeth in situ in the maxilla and mandible - left and right $\mathrm{i} / 1$, left $\mathrm{i} / 2$, parts of the left and right male canines (the tip of the left canine has gone missing since it was illustrated by Croizet \& Jobert [1828]), left $\mathrm{D} 2 /-\mathrm{D} 4 /, \mathrm{M} 1 /$, left $\mathrm{d} / 2-\mathrm{d} / 4, \mathrm{~m} / 1-\mathrm{m} / 2$, p/4 in crypt, right $\mathrm{d} / 2-\mathrm{d} / 4, \mathrm{~m} / 1, \mathrm{p} / 4$ in crypt. The lectotype of "Sus" minor is a left mandible containing $\mathrm{p} / 2-\mathrm{p} / 4, \mathrm{~m} / 1-\mathrm{m} / 2$.

\section{DESCRIPTION}

\section{Musaitu suid skull}

The Pliocene deposits at Musaitu, Moldova, yielded a remarkable skull of Dasychoerus arvernensis rivalling in completeness the material from Roussillon, France (Azzaroli 1975; Berdondini 1992) (Figs 9-14). The skull is notable for the narrow posterior cranial table, forming a narrow crest distally somewhat in the style of Euhys barbatus (Müller, 1838) (Gray 1868) and narrower than is usually the case in Dasychoerus verrucosus. The morphology of the brain case appears to be close to that of the Kvabebi suid described by Vekua (1972) although distortion of the latter specimen renders detailed comparisons difficult. A difference from the Kvabebi skull is the slightly convex longitudianl dorsal profile of the Musaitu skull, which is dished in the Kvabebi specimen (perhaps enhanced by crushing).

In lateral view the slightly convex dorsal transverse profile of the skull is evident, with a low swelling between the supra-orbital grooves in front of the supra-orbital foramina. The dorsal longitudinal profile of the nasals is very gently concave, almost flat. Although the anterior ends of the nasals are broken off, and the rear of the braincase is damaged, it is evident that the splanchnocranium was much longer than the neurocranium, as measured from the anterior margin of the orbit (Azzaroli 1954). The orbit lies behind the level of the upper third molar and is high on the face, bordered anteriorly by the lacrimal in which there are two prominent foramina. The post-orbital process ends in a sharp point above the mid-height of the orbit. In front of the orbit there is a well developed fossa for the origin of the levator rostri snout musculature (Ewer 1958). This fossa has a clear dorsal margin which leads forwards to the region above the canines, implying a well developed rooting habit in this species. The facial crest that separates the origin of the levator rostri from that of the dilator naris lateralis and the depressor rostri terminates short of the infra-orbital foramen. The infra-orbital foramen is large and lies at mid-height of the snout above the $\mathrm{P} 4 /-\mathrm{M} 1 /$. Above and just behind the canine alveolus there is a canine flange with a smooth concave dorsal surface over which passed the tendons for 

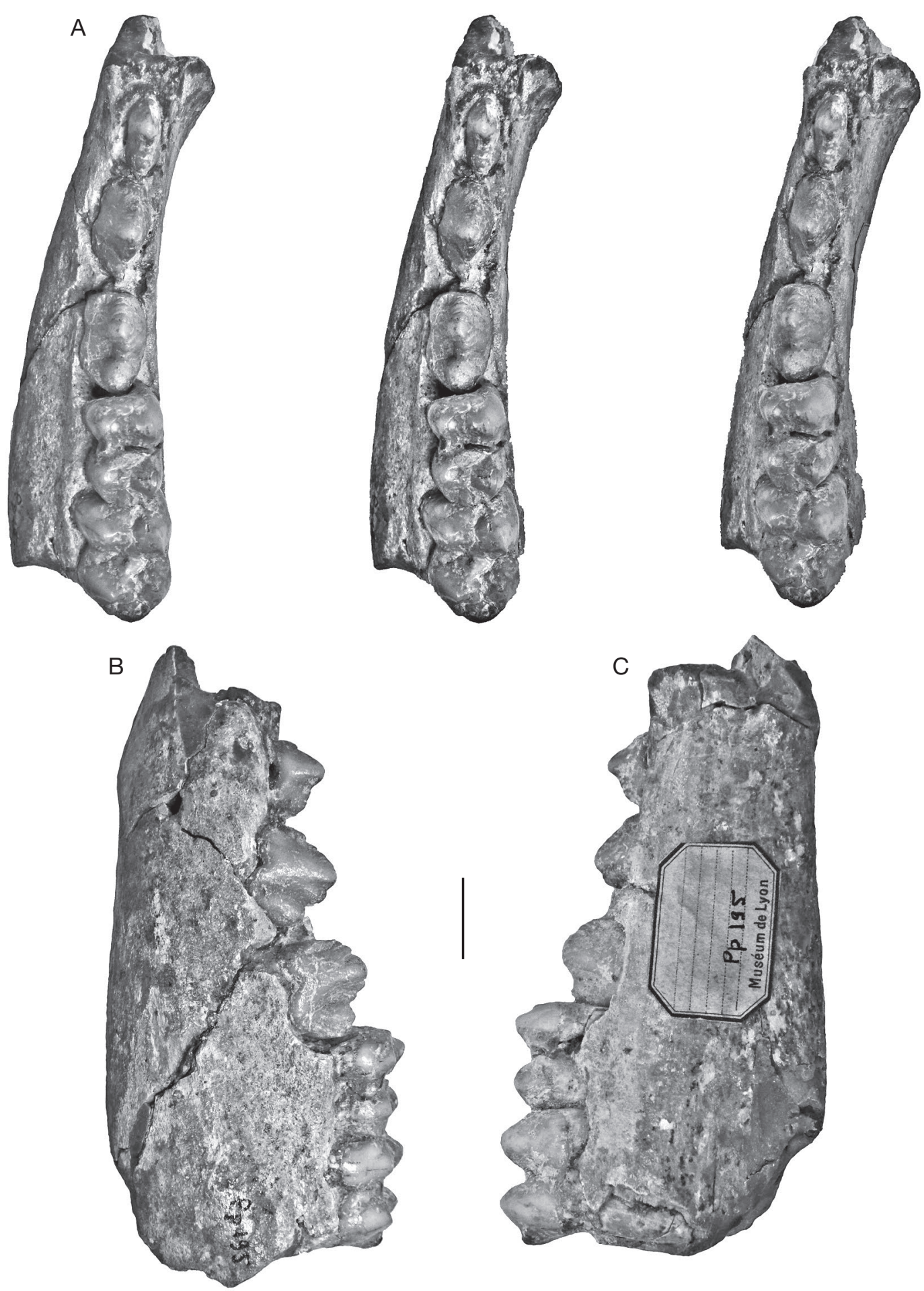

FIG. 8. - Left mandible containing p/2-m/2, from Perpignan, France (CCECL Pp 195), lectotype of "Sus" minor (Depéret, 1890) (Azzaroli 1954): A, stereo triplet of the occlusal view (note the thickness of the mandible despite the juvenile status of the jaw; B, buccal view; C, lingual view. Scale bar: 10 mm.

the snout musculature. At the canine level, the ventral part of the snout descends beneath the occlusal surface of the cheek teeth. The canine is inserted at the anterior ventral end of the supra-canine flange.

In dorsal view, the skull is observed to be long and narrow, broadest at the post-orbital processes, narrowing sharply distally, and narrowing more gently anteriorly. The infra-orbital foramina emerge from the skull roof in line with the front of the orbits, and the supra-orbital grooves follow a slightly curved course anteriorly along the dorsal surface of the skull, first approaching each other, and then running sub-parallel to each other. The temporal crests approach each other distally but do not form a true sagittal crest. The degree of narrowing of the braincase distally is 


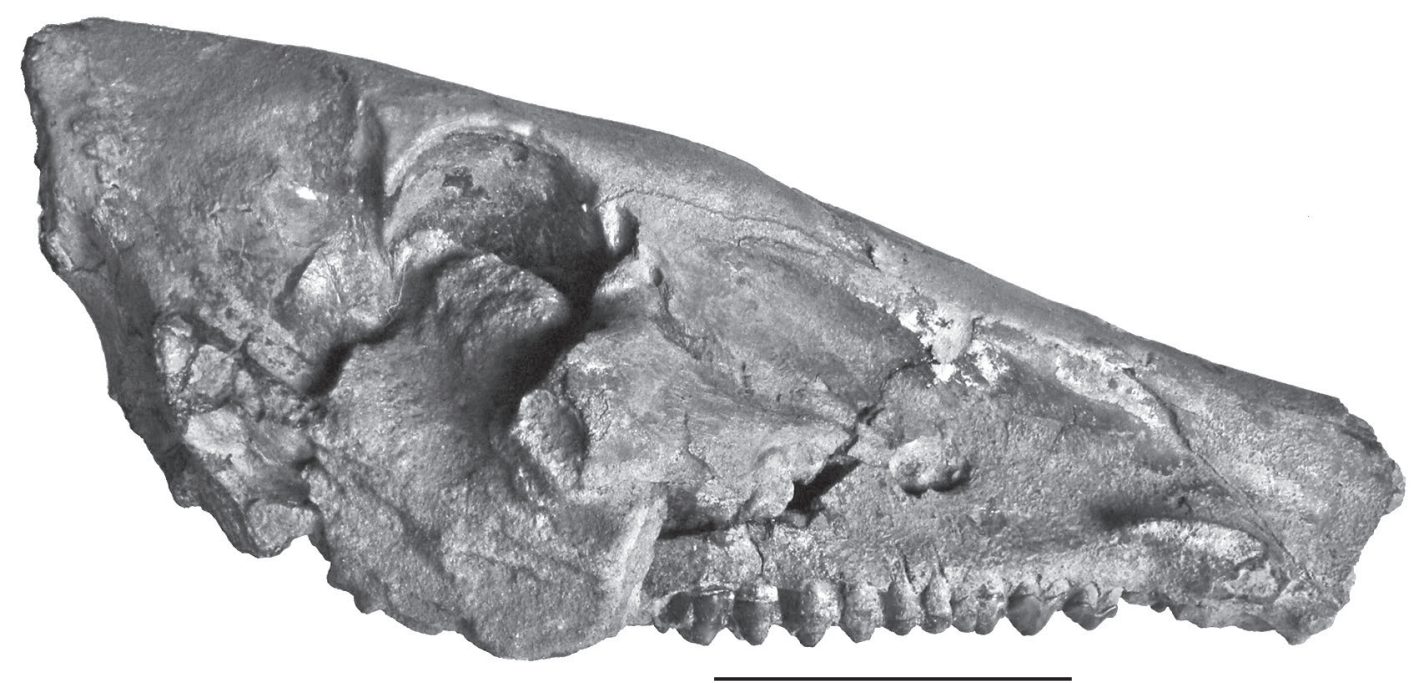

FIG. 9. - Skull of Dasychoerus arvernensis (Croizet \& Jobert, 1828) from Musaitu, Moldova, right lateral view. Note the downward bend of the ventral part of the snout in front of the alveoli of $\mathrm{P} 1$ / (separated from the $\mathrm{P} 2 /$ by a short diastema) and the relatively thin supra-canine flange above and behind the canine alveolus. Also of note is the slightly convex dorsal transverse profile of the skull in front of, and above, the orbits, and the absence of dishing of the dorsal longitudinal profile of the skull. Scale bar: $10 \mathrm{~cm}$.

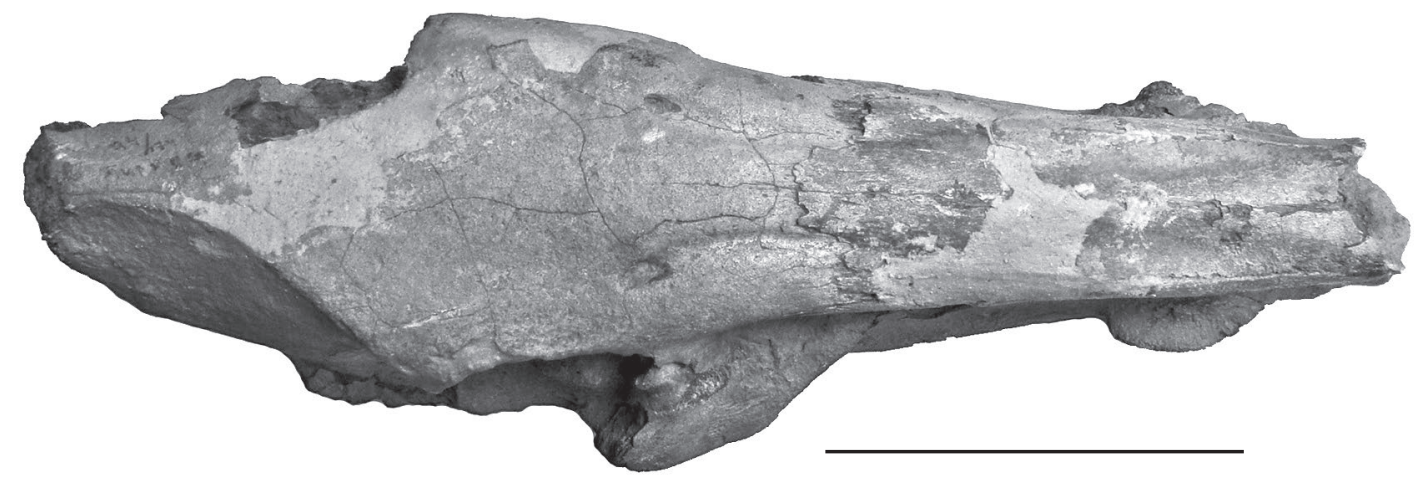

FIG. 10. - Skull of Dasychoerus arvernensis (Croizet \& Jobert, 1828) from Musaitu, Moldova, dorsal view. Note the temporal crests that approach each other distally almost forming a sagittal crest. Scale bar: $10 \mathrm{~cm}$.

comparable to that seen in Euhys barbatus. It is narrower than is usually the case in Dasychoerus verrucosus (ForsythMajor 1897) and Sus scrofa, and quite similar to the fossil South African form Potamochoeroides hypsodon Dale, 1948 (Pickford 2013b). The zygomatic arches are broken, but the root of the right one shows that it departs from the face at an angle of $c .45^{\circ}$ with its anterior end above the $\mathrm{M} 2 /$, just behind the infra-orbital foramen.

The supra-canine flange projects from the face above and behind the canine alveolus, its dimensions and that of the canine alveolus suggest that this was probably a juvenile male in which the flange had not grown to its fully mature form. The dimensions of the canine root support this diagnosis. The snout is rectangular in section, with almost vertical sides.

In palatal view, the lingual edges of the two cheek tooth rows are sub-parallel. The teeth are well preserved with the P2/-M3/ forming a closed series separated by a short diastema from the P1/, represented by two alveoli just behind the canine alveoli which contain remnants of the root of the canine. The front parts of the palatines are broken so no information can be provided about the incisors. The supracanine flange is positioned such that the canines emerged from its anterior end, and its rear margin is opposite the P2/. The individual was a young adult at the time of death, as revealed by the fact that M3/ is not completely erupted but the cusp apices of the anterior loph have reached the same level as the occlusal surface of the teeth in front of it. The posterior choanae open up a short distance behind the rear of the M3/s. The basicranial area of the skull is badly damaged.

In anterior view, the section of the snout is visible where the anterior part has broken off. This shows that the lateral walls of the rostrum are vertical, the nasal cavity is comprised of two lobes, a large one dorsally and a smaller one ventrally. The dorsal surface of the rostrum shows a low ridge in the midline.

In posterior view, the nuchal zone is observed to be tall and relatively narrow. The basicranium is broken. 

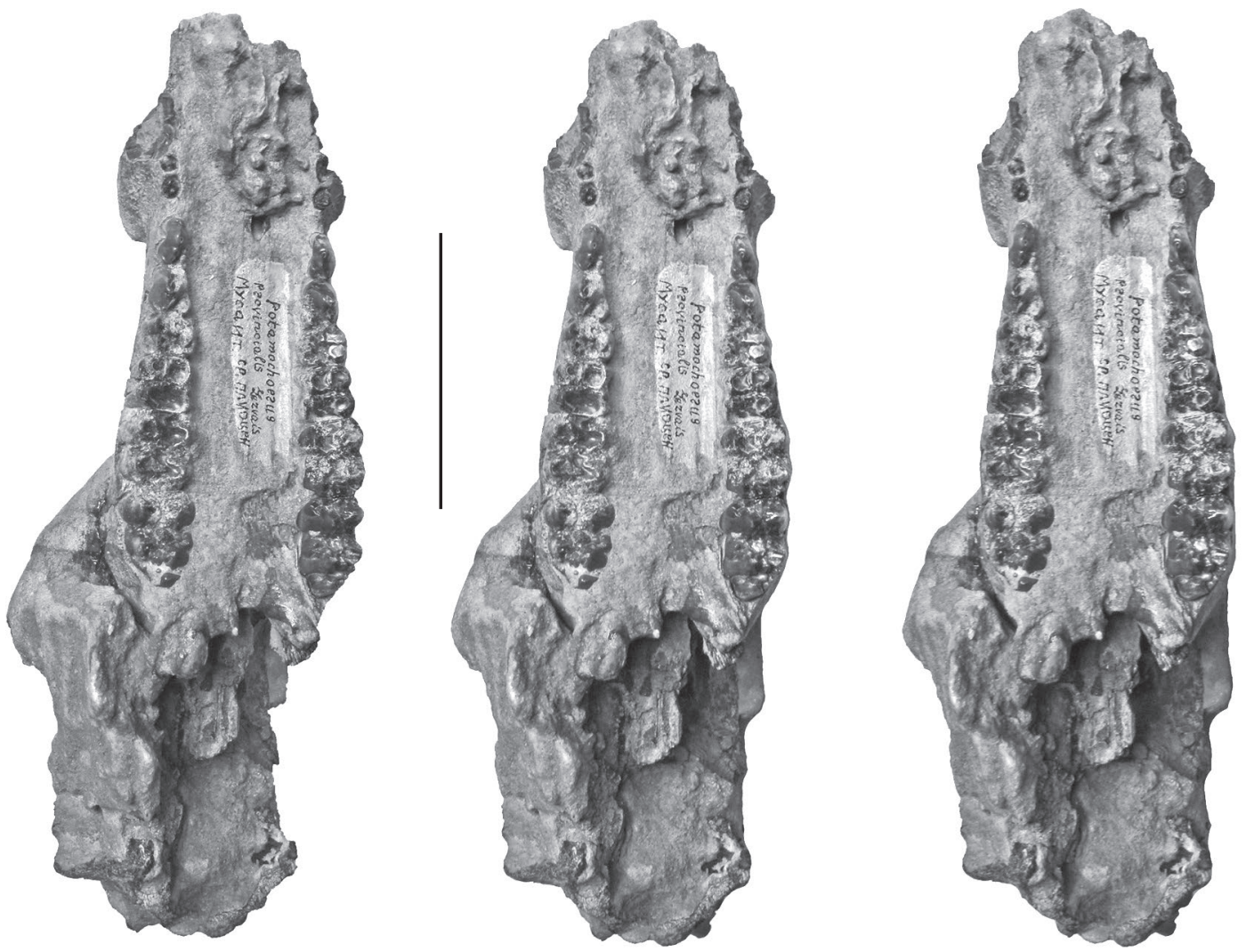

FIG. 11. - Skull of Dasychoerus arvernensis (Croizet \& Jobert, 1828) from Musaitu, Moldova, stereo triplet ventral view. Note in particular the canine flanges, the short diastema between the P1/ and the P2/ and the position of the posterior choanae behind the M3/s. Scale bar: $10 \mathrm{~cm}$.
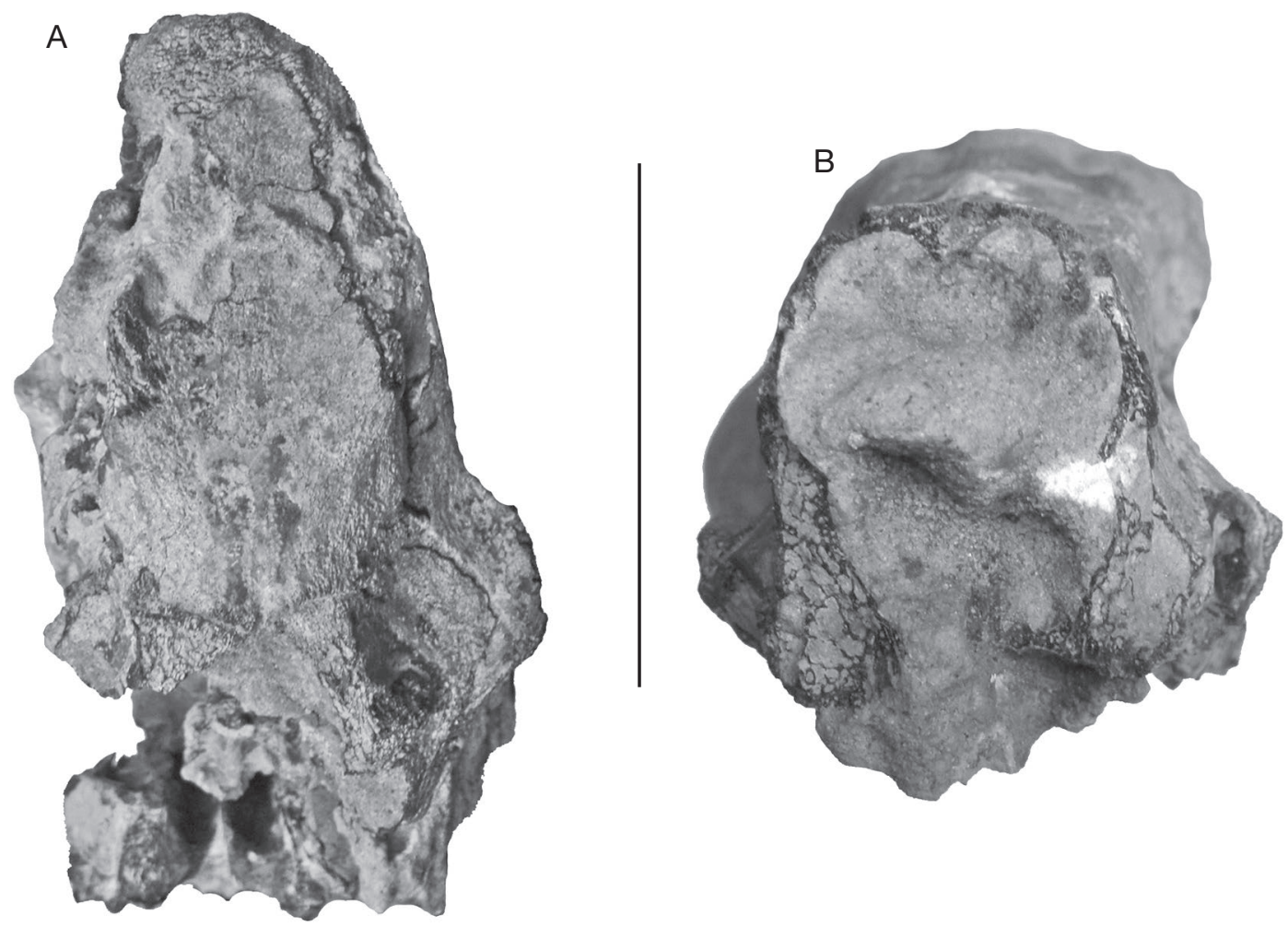

FIG. 12. - Skull of Dasychoerus arvernensis (Croizet \& Jobert, 1828) from Musaitu, Moldova: A, posterior view showing the tall, narrow surface for attachment of the nuchal musculature; B, anterior view showing vertical lateral walls of the snout and the carbonate-rich sediment infilling the nasal cavity. Note the ridged dorsal profile of the rostrum, and the indentations in the sides of the nasal cavity dividing it into broader upper and narrower lower parts, the latter floored by the palate. Note also the large concretion obscuring the palate. Scale bar: $5 \mathrm{~cm}$. 

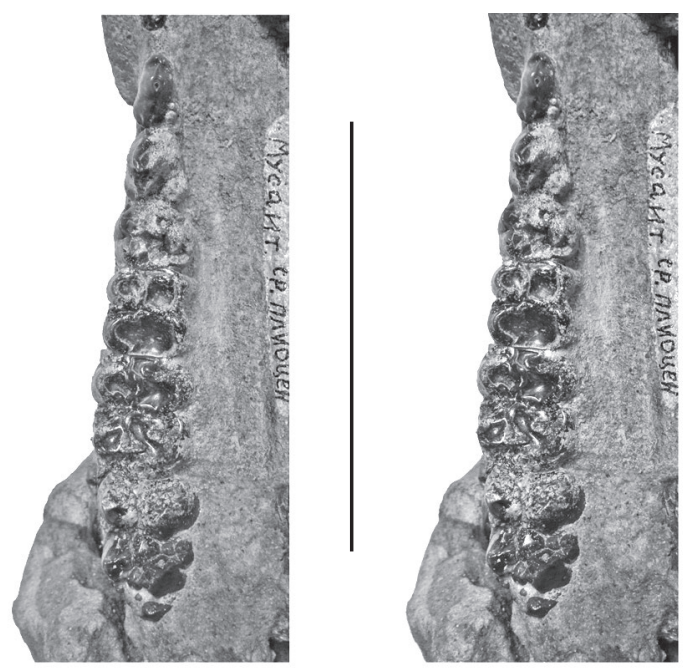

FIG. 13. - Right cheek teeth of the skull of Dasychoerus arvernensis (Croizet \& Jobert, 1828) from Musaitu, Moldova, stereo occlusal view. Scale bar: $10 \mathrm{~cm}$.

\section{Dentition}

$\mathrm{P} 1$. The $\mathrm{P} 1 /$ is missing on both sides but it had two roots. It is positioned just behind the canine alveolus and slightly lingual to the inner edge of the canine alveolus.

$\mathrm{P} 2$. The $\mathrm{P} 2$ / is subtriangular in occlusal outline, with rounded apices of the triangle. The main cusp is somewhat anterior to the midline of the tooth. It has a precrista that descends towards a small mesial cusplet, and a prominent, swollen postcrista that forms a separate cusplet distally. There is a slight incision in the postcrista which separates the main cusp from the distal one. Disto-lingually, there is a small cingular cusplet separated from the rest of the crown by the distal fovea. Thus the rear of the tooth is broader than the front half.

P3. The P3/ has a broad triangular occlusal outline. It is constructed along the same lines as the P2/ but all the structures are better defined and larger. Thus the mesial cusplet at the anterior end of the precrista is more prominent and has cingular folds extending medially and laterally from it for a short distance, but not reaching the buccal side of the crown. The distal cusplet on the buccal side is larger and is better separated from the main cusp by lingual and buccal grooves. The distal fovea is broader than in the $\mathrm{P} 2 /$ and the disto-lingual cusplet is larger, connected to a low cingulum that extends along the lingual base of the crown.

$\mathrm{P} 4$. The $\mathrm{P} 4 /$ is tricuspid, and rectangular in occlusal outline. There are two buccal cusps, the posterior one as tall as the main cusp but mesio-distally smaller than it. These two cusps are separated from each other on the buccal side by a prominent vertical groove that reaches almost to the cervix. There is a prominent protocone on the lingual side of the tooth, connected to cingula that extend anteriorly and posteriorly to join the mesial and distal cingula respectively. There is a sagittal cusplet on the lingual side of the paracone, but there is none on the lingual side of the metacone.
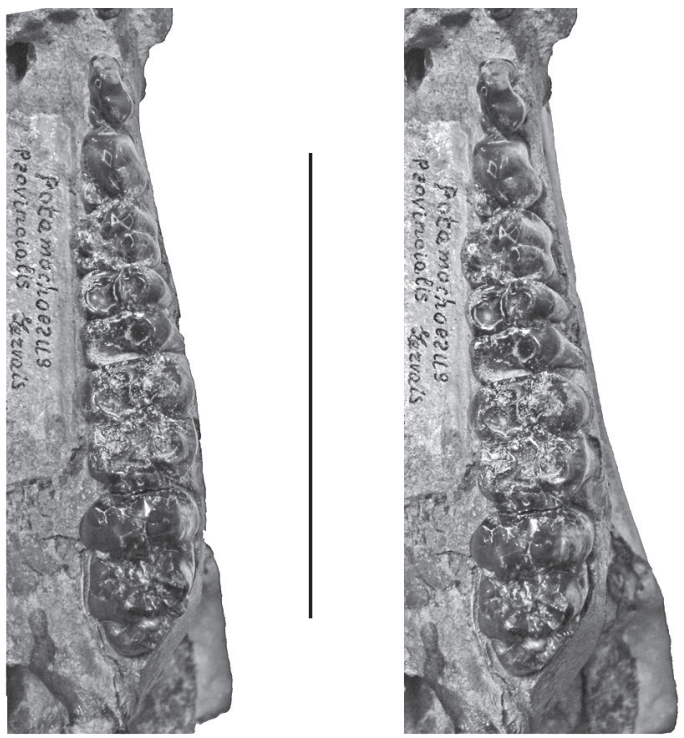

FIG. 14. - Left cheek teeth of the skull of Dasychoerus arvernensis (Croizet \& Jobert, 1828) from Musaitu, Moldova, stereo occlusal view. Scale bar: $10 \mathrm{~cm}$.

$\mathrm{M} 1 /$ and $\mathrm{M} 2 /$. The M1/ is deeply worn. The M2/ is also heavily worn, but shows four main cusps arranged in two lophs with a prominent median accessory cusplet blocking the median transverse valley. There are well formed mesial and distal cingula and there is a remnant of a lingual cingulum in the lingual end of the median transverse valley.

M3. The M3/s are lightly worn and show all the main structures well. This tooth has four main cusps and anterior, median and posterior accessory cusplets, as in the M2/ (the usual basic morphology found in suids) but in addition, at the rear of the crown, there is a small talon comprised of a low, pointed cusp slightly to the lingual side of the midline of the crown. The mesial cingulum is beaded and ends before reaching the buccal or lingual part of the crown. It ends lingually at a small cingular cusplet attached to the mesio-lingual corner of the protocone. The lingual end of the median transverse valley shows a low cingular remnant, and there are cingular beads of enamel at the lingual and buccal ends of the valley between the rear loph and the talonid of the tooth. The Fürchen are shallow apically but clearly discernible, especially towards the bases of the main cusps where they are deeper and broader.

\section{Dermenji mandible}

A mandible fragment from Dermenji curated at the Musée des Complexes Faunistiques Fossiles de Moldova, Institut de Zoologie, Académie des Sciences de Moldova, comprises the rear part of the right ramus containing $\mathrm{m} / 2$ and $\mathrm{m} / 3$ in medium wear (Fig. 15). The $\mathrm{m} / 2$ has four main cusps arranged in two lophs with clear anterior, median and posterior accessory cusplets in the midline of the crown. The two lophids are wide apart. The two anterior lophids of the $\mathrm{m} / 3$ have the same basic structure as the $\mathrm{m} / 2$, but in addition, there is a prominent talonid cusp behind 

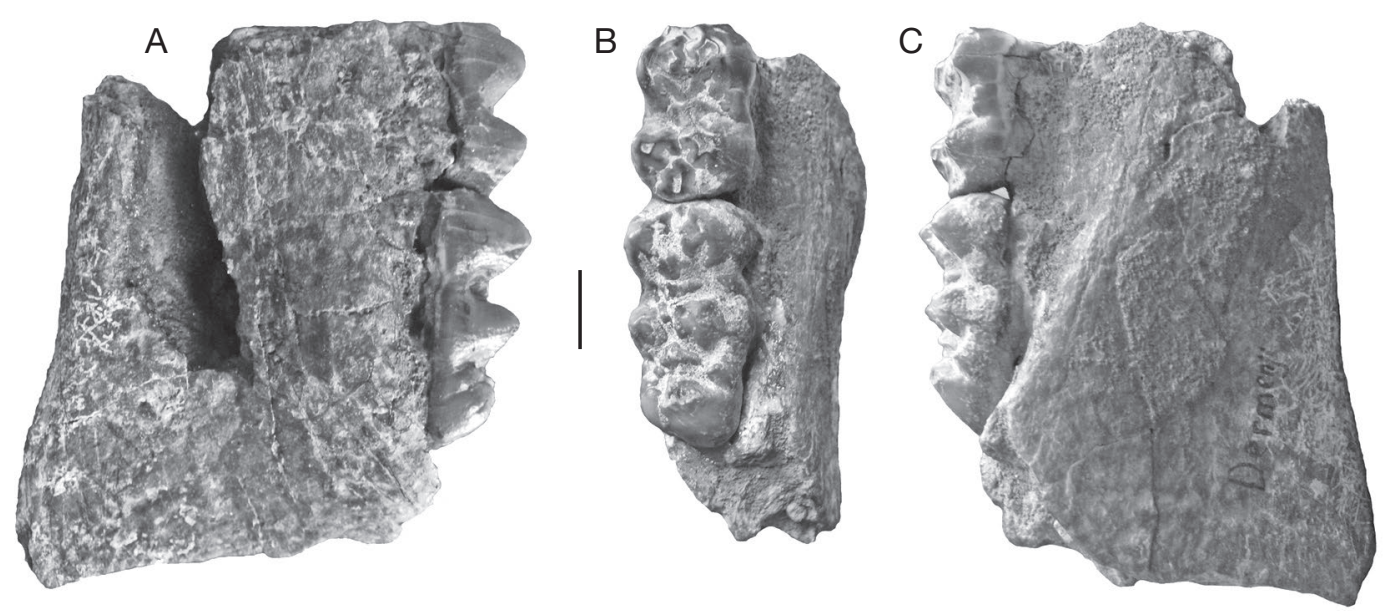

FIG. 15. - Right mandible of Dasychoerus arvernensis (Croizet \& Jobert, 1828) from Dermenji, Moldova: A, lingual view; B, occlusal view; C, buccal view. Scale bar: $10 \mathrm{~mm}$.

the posterior accessory cusplet in the centre-line of the crown. The teeth in this specimen resemble those from Gödöllö, Hungary (Mottl 1939) and Perpignan, France (Depéret 1890).

\section{Metric analysis}

Appendices 1 (Europe) and 2 (Africa) provide measurements of the teeth used in the metric analysis.

The dental metrics of the Musaitu and Dermenji suids show close correspondence with material of Dasychoerus arvernensis from other localities in Europe (Figs 16-19). The specimens are smaller than the suids from Kvabebi, Georgia (Vekua 1972) although there are some morphological resemblances in the skulls from Musaitu and Kvabebi, such as the presence of a narrow cranial table distally, almost forming a sagittal crest, and well developed supracanine flange. However, the dorsal surface of the Kvabebi skull has a dished profile in lateral view, and the specimen from Musaitu is slightly convex, almost straight. The Kvabebi specimen is distorted, and this may have altered the profile, but even so, the difference seems to be important. Similar dishing of the skull occurs in the African genus Kolpochoerus, and it could be that the Kvabebi morphology represents an intermediate stage between Dasychoerus arvernensis as exemplified by the almost straight, slightly convex condition seen not only in the Musaitu skull but also in the material from Roussillon and Villafranca d'Asti (Azzaroli 1954, 1975; Berdondini 1992) and the dished condition observed in Kolpochoerus.

The Kvabebi suid (Vekua 1972) has thickened mandibular rami, as do specimens from Roussillon and Villafranca d'Asti (Figs 20,21), and the same condition occurs in Kolpochoerus. There can be little doubt that the African kolpochoeres, Dasychoerus arvernensis and the Kvabebi suid are closely related members of a lineage or clade.

The larger of the specimens attributed to Kolpochoerus millensis are similar in size to the suid from Kvabebi, Georgia (Vekua 1972) (Figs 22, 23).
The upper and lower third molars attributed to the Ethiopian species Kolpochoerus millensis (Haile-Selassie \& Simpson 2012) have a somewhat greater range of length variation than the closely related taxon Dasychoerus arvernensis. Many of the former specimens fall within the range of variation of the latter species but there are a few more elongated teeth. Whether this is related to a real increase in variability of the length of the teeth, or whether it is due to the mixing of two closely related taxa needs to be examined. The authors did not provide measurements of the other cheek teeth of Kolpochoerus millensis, so it is not possible to determine whether they too show an increase in variability over the situation in Dasychoerus arvernensis. It is clear however, that the larger of the specimens attributed to Kolpochoerus millensis overlap in length dimensions with the Kvabebi suid, although the latter material has broader third molars than K. millensis.

\section{Boreal, sub-tropical and tropical suids}

As in other artiodactyl groups there are suids adapted to high latitudes and others to low latitudes. A major difference between these groups concerns the timing of reproduction related to seasonal changes in climate. Boreal taxa time their reproduction to winter-summer cycles whereas more tropical lineages time their reproduction to wet season - dry season cycles. The metabolic triggers for reproductive activity differ between the groups, in high latitudes the hormonal changes are linked to variations in day length which are highly predictable. The Wild Boar (Sus scrofa) times its reproductive cycle such that litters are born in spring (MacDonald 2001) whereas in the tropics suid reproduction is linked to changes in humidity which are much more variable in timing, partly due to the El Niño phenomenon. In the humid tropics where the seasons are not marked, reproduction may occur all the year round, but where there is marked dry-wet cyclicity, birth is usually timed to occur near the beginning of the wet season, but with marked variability due to vagaries in the onset of the different seasons. 

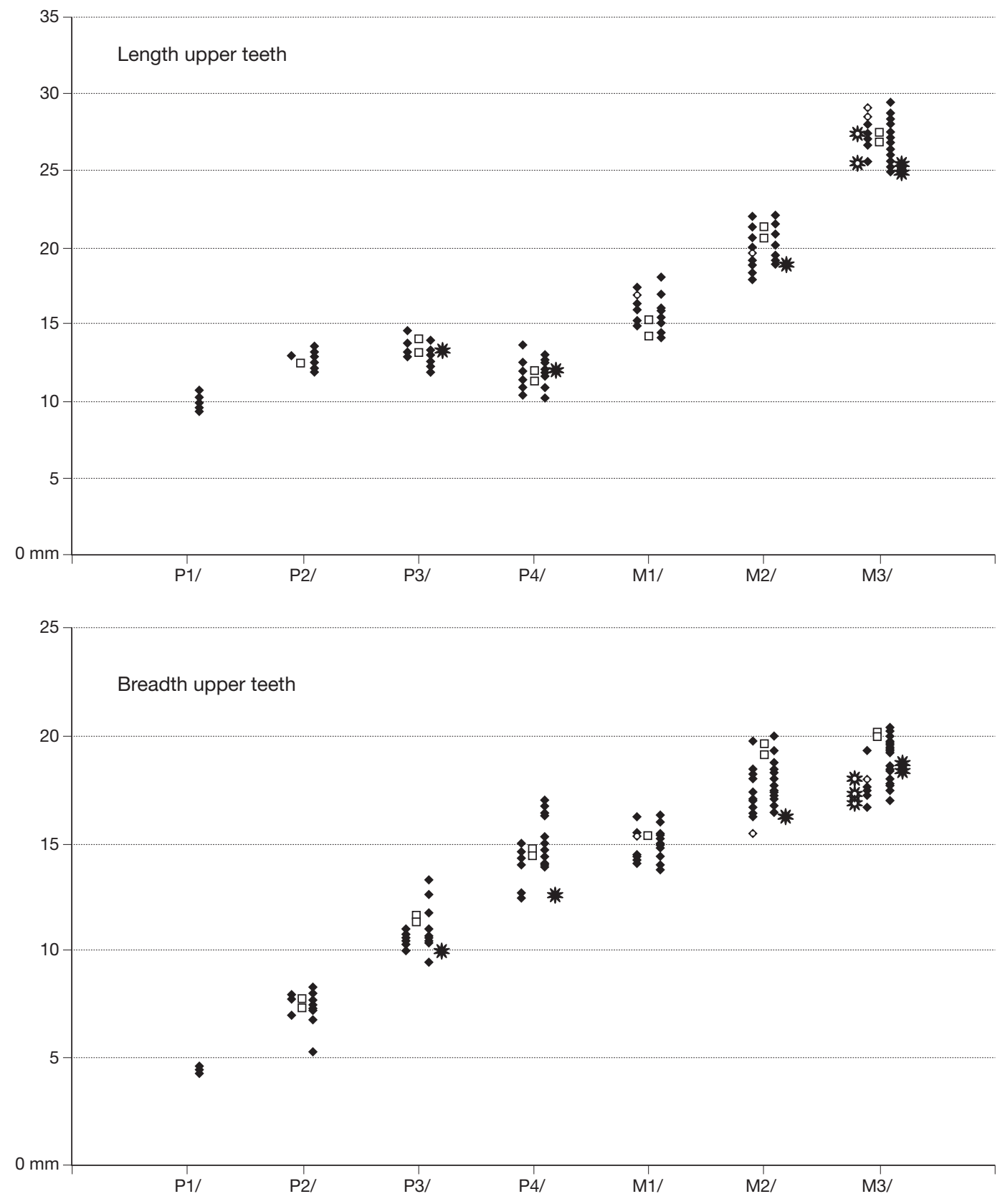

FIG. 16. - Length and breadth plots of the upper cheek teeth of Dasychoerus arvernensis (Croizet \& Jobert, 1828) from Europe and Africa. In the midline ( $\square$ ) are the measurements of the teeth in the Musaitu skull. To the left are measurements of teeth from Les Étouaires ( $\diamond)$ and Roussillon (Perpignan) ( $\bullet$ ) and to the right are measurements of teeth from Afyonkarahisar, Alcoy, Autrey, Auvergne, Bra, Çalta, Capeni, Dinar Akçakoy, Gödöllö, Hajnacka, Herbolzheim, Ivanovce, Milia, Trévoux, Virgis, and Villafranca d'Asti (see Appendix 1 for data sources). Further to the right are specimens from Ethiopia (**) and further to the left are specimens from Chad (*) (Appendix 2).

This translates into divergent controls of reproductive behaviour in Sus Linnaeus, 1758 and Dasychoerus, the Wild Boar (Sus scrofa) being adapted to boreal environments with marked day length changes through the year, whereas the more tropical Warty Pigs (Dasychoerus) and their relatives the Wart Hog (Phacochoerus Cuvier, 1826) the Red River Hog (Potamochoerus) and the Forest Hog (Hylochoerus) are adapted to tropical environments where day length changes are not as marked as they are at high latitudes. Thus not only do reproductive parameters link Dasychoerus, Phacochoerus, Potamochoerus and Hylochoerus, to the exclusion of Sus, but so do the presence of warts, lower canine morphology (verrucosic), style of intraspecific combat during the rutting season among others (MacDonald 2001). The definition of verrucosic canines is based on the sub-equal dimensions of the lingual and labial enamel-covered surfaces of the tooth. In scrofic canines the labial surface is appreciably shorter than the lingual surface. The distal, enamel-free surface can be broad or narrow in both types. Of course, the measurements should be taken on the unworn part of the tooth, because wear can give a false scrofic section to a verrucosic underlying morphology. By these criteria, the canines of Potamochoerus are verrucosic. 

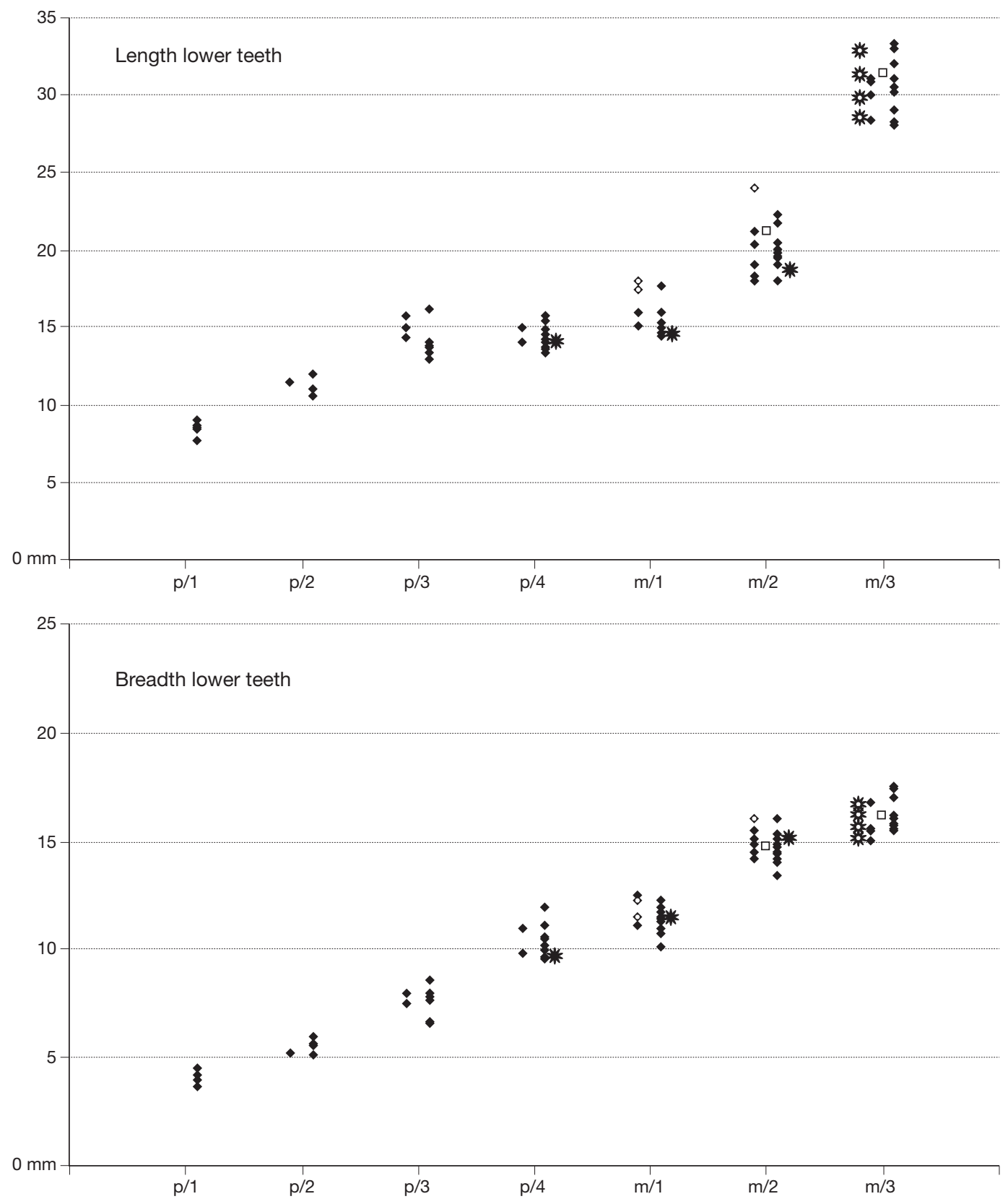

FIG. 17. - Length and breadth plots of the lower cheek teeth of Dasychoerus arvernensis (Croizet \& Jobert, 1828) from Europe. In the midline ( $\square$ ) are the measurements of the teeth in the Dermenji mandible. To the left are measurements of teeth from Les Étouaires ( $\diamond)$ and Roussillon (Perpignan) ( $\bullet$ ) and to the right are measurements of teeth from Afyonkarahisar, Alcoy, Autrey, Auvergne, Bra, Çalta, Capeni, Dinar Akçakoy, Gödöllö, Hajnacka, Herbolzheim, Ivanovce, Milia, Trévoux, Virgis, and Villafranca d'Asti (see Appendix 1 for data sources). Further to the right are specimens from Ethiopia (*) and further to the left are specimens from Chad (*) (Appendix 2).

\section{Reproductive potential of Suidae}

Species of Sus (sensu lato) differ from most other artiodactyls by their reproductive potential. They are the only group to give birth to several offspring at a time (litters range from one to twelve in Sus) (Table 1). Other suids tend to give birth to fewer offspring (one to six in Porcula Hodgson, 1847 and one to two in Babyrousa Perry, 1811, usually two in Phacochoerus (but as many as four have been observed by the senior author), and perhaps two in Hylochoerus). Peccaries usually give birth to fewer offspring (one to four, usually two) and most other artiodactyls only one or two offspring at a time. Given that in
Sus scrofa sexual maturity is attained at 18 months, gestation is 115 days and life span ranges from 15 to 20 years, a sow that starts breeding at an age of two years may leave behind an astonishing number of descendents, especially if she breeds twice each year (White 1788).

\section{Rates of evolution}

A consequence of having large litters and relatively short generation times (Table 1) is that evolution seems to have occurred more slowly when compared with other artiodactyls which have only one or two offspring per pregnancy and 

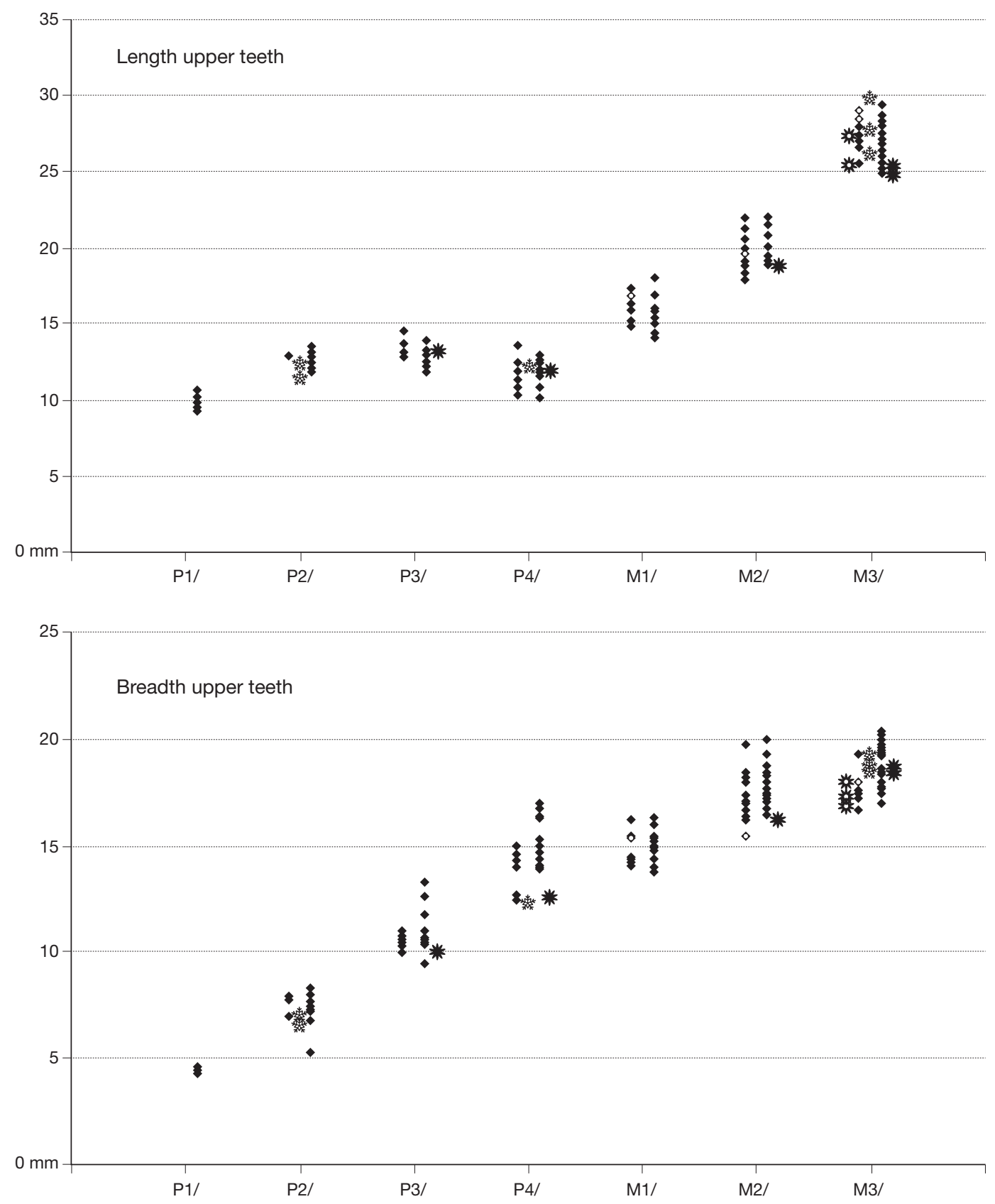

FIG. 18. - Length and breadth of upper cheek teeth of Dasychoerus arvernensis (Croizet \& Jobert, 1828) from Europe and Africa (Mabaget Formation, Tugen Hills, Kenya). Symbols are the same as in Figures 16 and 17, except that the hollow snowflake symbol (

successive pregnancies more spaced apart. Suids with fewer offspring per pregnancy and longer gestation periods, such as Phacochoerus and Hylochoerus, appear, from their fossil record, to have evolved more rapidly than those lineages that have larger numbers of offspring (Sus scrofa, for example). The same probably applies to Babyrousa, which departs greatly from the basic suid grundplan as exemplified by Sus. Possessing warts, the babyrussa may be more closely related to Dasychoerus than to other suids.

There is debate about the possibility of a link between rates of evolution and reproductive strategies (K-strategy, r-strategy) in mammals, with evolution often occurring more rapidly in
K-strategists such as proboscideans, than in r-strategists such as many rodent taxa. However, some K-strategists, including rhinocerotids, underwent slow evolution. For this reason, rates of evolution in suines requires further study, but at present, the fossil record seems to support the notion that r-strategists such as Sus scrofa evolved more slowly than K-strategists such as Phacochoerus.

\section{PHYLOGENY}

\section{Molecular evidence}

Molecular techniques have thrown some light on relationships among extant suid lineages, although the results are actively debated without any firm consensus emerging from 

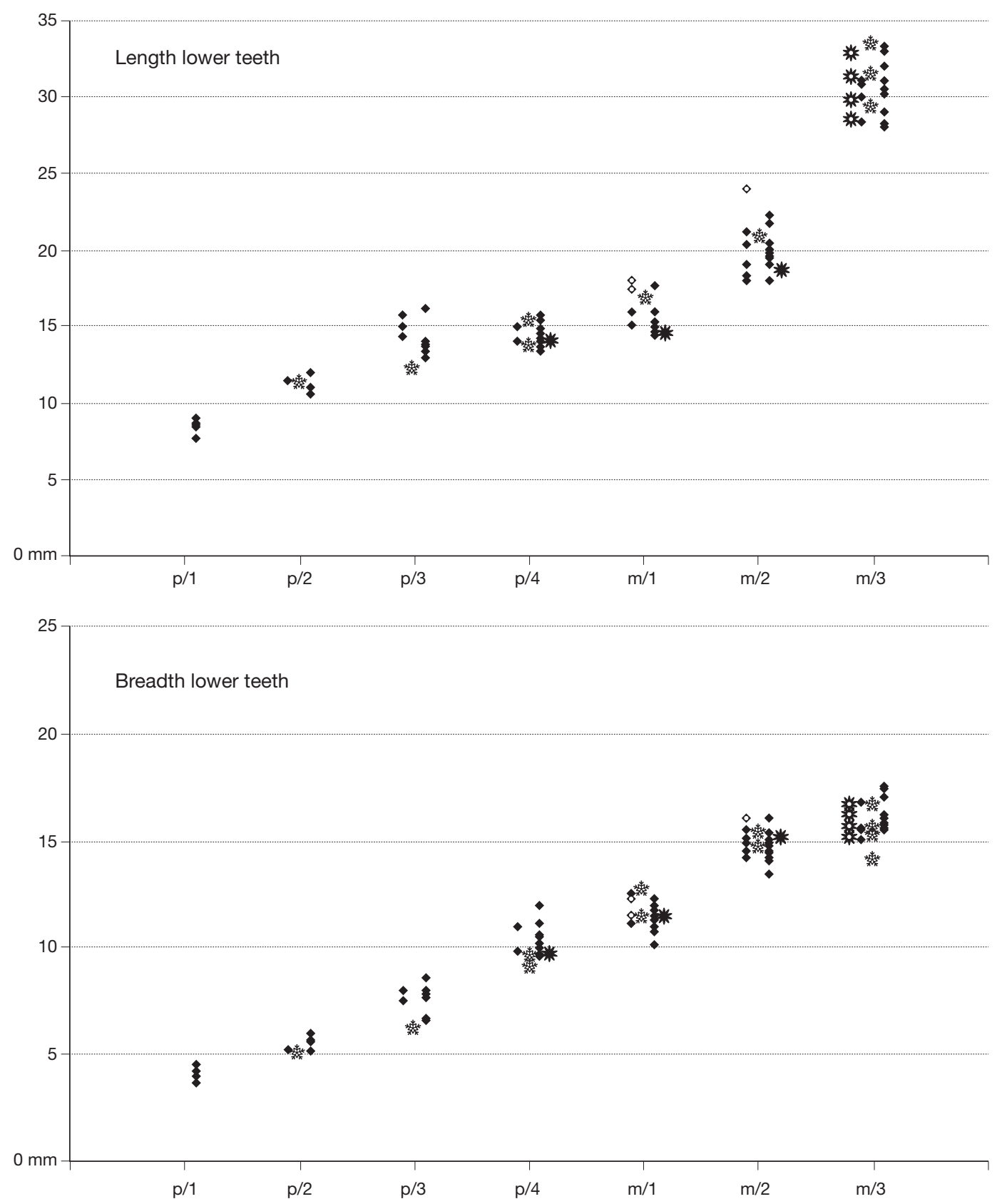

FIG. 19. - Length and breadth of lower cheek teeth of Dasychoerus arvernensis (Croizet \& Jobert, 1828) from Europe and Africa (Mabaget Formation, Tugen Hills, Kenya). Symbols are the same as in Figures 16 and 17, except that the hollow snowflake symbol (赫) in the middle line refers to the fossils from Mabaget.

the studies (Wu et al. 2006; Funk et al. 2007; Gongora et al. 2010; Frantz et al. 2013). The genus Porcula, for example, was for many years included in the genus Sus as a sister taxon of Sus scrofa (sometimes as a subgenus Porcula [Herre 1962]) with other species of Sus more distantly related. Porcula is now considered by some researchers (Funk et al. 2007) to represent a genus distinct from Sus, which means that some of the other species traditionally included in the genus Sus need to be reclassified into a separate genus or genera. From a morphological perspective two or three subgroups have been commonly recognised among the species hitherto included in Sus (Groves 1981, 1997;
Groves \& Grubb 1993): 1) non-warty pigs (Sus scrofa and Porcula salvania Hodgson, 1847); and 2) warty pigs (all other species of "Sus"). Subdivision on the basis of lower canine morphology yields almost the same categories except that the "warty" subgroup is capable of further subdivision into two clusters: $2 \mathrm{a}$ ) the philippensis group; and $2 \mathrm{~b}$ ) the verrucosus group. "Sus" philippensis poses particular problems because it is a "warty" pig, whereas some molecular analyses suggest closer affinities to Sus scrofa than to the other warty pigs (Funk et al. 2007). Warts occur in the African warthog, indicating possible phylogenetic links with the "warty" pigs, and so does the Giant Forest Hog 


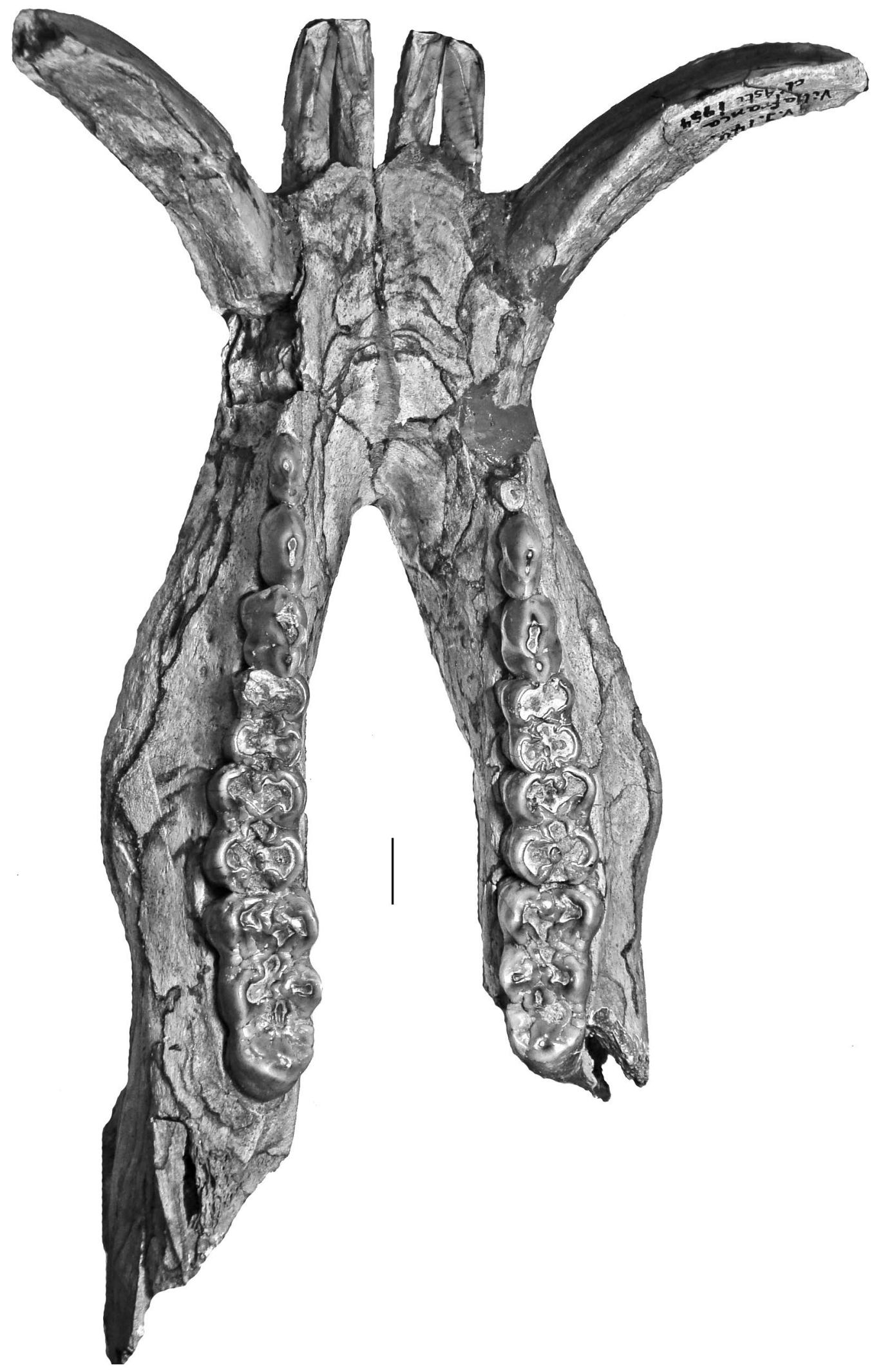

FIG. 20. - Mandible of Dasychoerus arvernensis (Croizet \& Jobert, 1828) from Villafranca d'Asti, Italy (NHMB VI 144), showing thick mandibular bodies, one of the defining characteristics of the genus Dasychoerus Gray, 1873. Scale bar: $10 \mathrm{~mm}$.

(Hylochoerus) (Ewer 1970). The bush pig (Potamochoerus) has thickened skin patches on the face (Ewer 1958) and some authors (MacDonald 2001) report that males have these structures. This suggests that the presence of facial warts represents a derived (autapomorphic) feature of the group. 


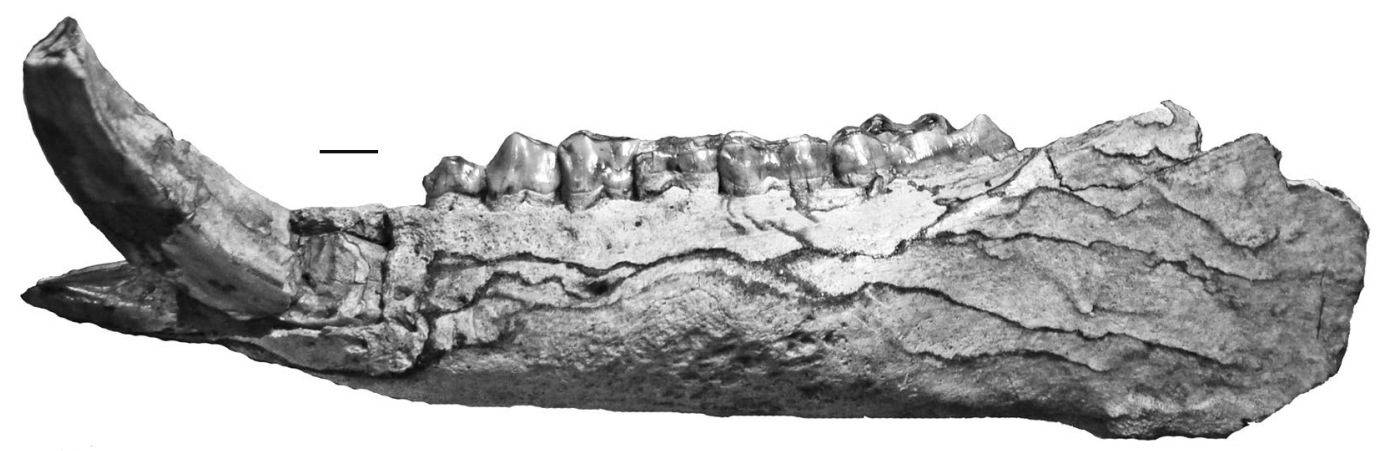

FIG. 21. - Left lateral view of male mandible of Dasychoerus arvernensis (Croizet \& Jobert, 1828) from Villafranca d'Asti, Italy (NHMB VI 144), showing the procumbent incisors well beneath the level of the cheek teeth. Note the disproportionately small and low $\mathrm{p} / 2$ relative to $\mathrm{p} / 3$, a feature also found in Potamochoerus Gray, 1854. Scale bar: $10 \mathrm{~mm}$.

On the basis of whole-genome analyses, Frantz et al. (2013) recognised a deep split between Sus verrucosus and Sus scrofa. Their cladogram shows a single specimen of "Sus scrofa" plotting within the clade comprising Sus verrucosus + Sus barbatus Müller, 1838 + Sus celebensis Müller \& Schlegel, 1845 , and this is the subspecies Sus scrofa vittatus Boie, 1828 (Müller \& Schlegel 1845), from Sumatra, a tropical island form long ago considered by some authors (Lydekker 1915) (possibly in the basis of misidentified specimens see Forsyth-Major [1897]) to be specifically distinct from boreal populations of Sus scrofa. This raises questions about the taxonomic affinities of Sus scrofa vittatus - is it really a subspecies of Sus scrofa? Old literature refers this species to the genus Aulacochoerus Gray, 1873, of which it is the type species. However, there has been confusion about which specimens belong to "Sus" vittatus, who the author of the species name was (Boie 1828 or Müller \& Schlegel 1845) and where the type material came from (Java or Sumatra). According to Mees (1957) the lectotype of Sus vittatus is the skeleton numbered RMNH 13508, and the type locality is Tjikao aan de Tjitaroem, West Java, but according to Hardjasasmita (1987) the holotype is a skull from Padang, Sumatra (RMNH Ost "d" in image page 51, but erroneously cited as Ost "c" in the text). Forsyth-Major (1897) reidentified four of the six skulls that Gray (1873) attributed to Aulacochoerus vittatus - NHMUK $1362 \mathrm{f}$ as a juvenile Sus verrucosus, NHMUK 1362c and 1362d as Sus verrucosus amboinensis (Forsyth-major, 1897) and NHMUK 1362g as Sus verrucosus celebensis. Thus from its inception, the concept of the genus Aulacochoerus was based on misidentifications of at least four out of six skulls.

In summary, recent molecular biology studies of suids indicate that the so-called Warty Pigs (Dasychoerus) and Bearded Pig (Euhys) are more closely related to each other, than any of them are to the Wild Boar (Sus scrofa) (Gongora et al. 2010; Frantz et al. 2013) or to Phacochoerus (the outgroup in the study by Frantz et al. 2013). On the basis of the fossil record, Pickford (2013e) postulated that the Wart Hog lineage (Phacochoerus) split from the Warty Pig lineage (Dasychoerus) during the Late Miocene which would accord with the molecular data.
TABLE 1. - Summary of life history and morphological variables of some species of extant suids. -, data not available.

\begin{tabular}{|c|c|c|c|c|}
\hline Taxon & $\begin{array}{l}\text { Body } \\
\text { weight } \\
\text { (kg) }\end{array}$ & $\begin{array}{l}\text { Gestation } \\
\text { period } \\
\text { (days) }\end{array}$ & $\begin{array}{c}\text { Mammae } \\
\text { (pairs) }\end{array}$ & $\begin{array}{c}\text { Longevity } \\
\text { (years) }\end{array}$ \\
\hline $\begin{array}{l}\text { Sus scrofa } \\
\quad \text { Linnaeus, } 1758\end{array}$ & $50-200$ & 115 & 6 & $15-20$ \\
\hline $\begin{array}{l}\text { Porcula salvania } \\
\text { Hodgson, } 1847\end{array}$ & $6-9$ & 100 & 3 & $10-12$ \\
\hline $\begin{array}{l}\text { Euhys barbatus } \\
\text { (Müller, 1838) }\end{array}$ & 140 & 120 & - & - \\
\hline $\begin{array}{l}\text { Dasychoerus verrucosus } \\
\text { (Müller \& Schlegel, } \\
\text { 1845) }\end{array}$ & 185 & 120 & 6 & 14 \\
\hline $\begin{array}{l}\text { Dasychoerus celebensis } \\
\text { (Müller \& Schlegel, } \\
\text { 1845) }\end{array}$ & $50-350$ & - & 6 & - \\
\hline $\begin{array}{l}\text { Hylochoerus } \\
\text { meinertzhageni } \\
\text { Thomas, } 1904\end{array}$ & $130-275$ & $149-154$ & 3 & - \\
\hline $\begin{array}{l}\text { Phacochoerus } \\
\text { aethiopicus } \\
\text { (Pallas, 1767) }\end{array}$ & $50-100$ & $170-175$ & 2 & $12-15$ \\
\hline $\begin{array}{c}\text { Babyrousa babyrussa } \\
\text { Rafinesque, } 1815\end{array}$ & 90 & $125-150$ & 1 & 24 \\
\hline $\begin{array}{l}\text { Potamochoerus porcus } \\
\quad \text { (Linnaeus, 1758) }\end{array}$ & $50-120$ & 127 & 3 & $10-15$ \\
\hline
\end{tabular}

\section{Fossil evidence}

The morphometric resemblances between European and African Dasychoerus arvernensis, the Kvabebi suid, and Kolpochoerus phillipi are flagrant. The Kvabebi suid has pachygnathous mandibles, the dorsal profile of the skull is moderately dished, the lower incisors are well beneath the occlusal surface of the cheek teeth, and the lateral edges of the supra-canine flanges project upwards, all features observed in species of Kolpochoerus. Souron et al. (2013) listed two of these characters as unambiguous synapomorphies of the group comprising Potamochoerus, Hylochoerus and Kolpochoerus. The lateral extent of the zygomatic arches cannot be determined in the Kvabebi skull, due to damage, but what remains appears to be pneumatised. A dished cranial profile is listed by these authors as a synapomorphy of Hylochoerus and Kolpochoerus, but such a morphology also occurs in the Kvabebi skull. Furthermore, 

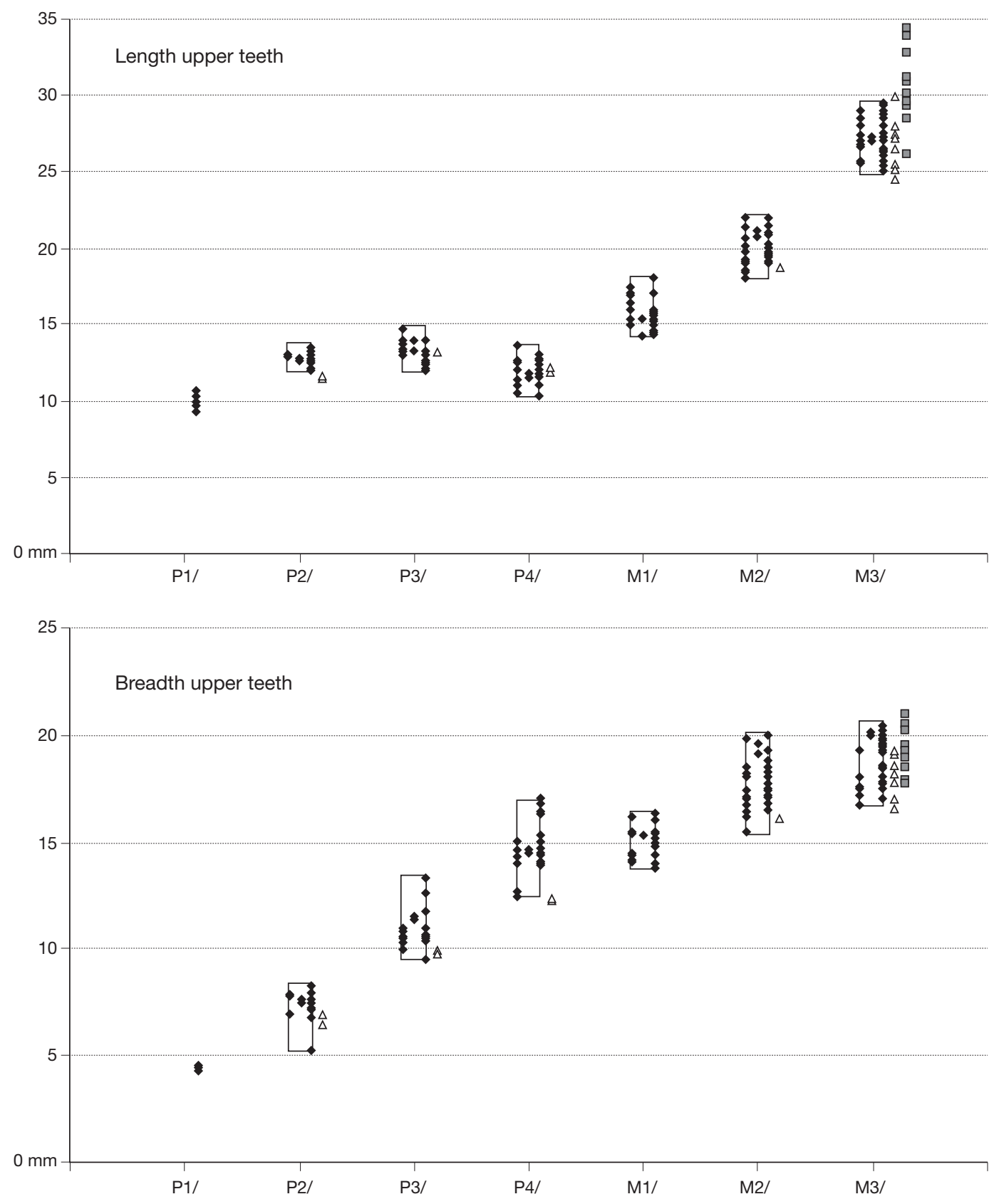

FIG. 22. - Comparison of dimensions of the upper cheek teeth of Dasychoerus arvernensis (Croizet \& Jobert, 1828) from Europe ( $\bullet$ ) and African fossils attributed to the same species (previously as Kolpochoerus deheinzelini Brunet \& White, $2001[\Delta]$ ) and the fossils attributed to Kolpochoerus millensis Haile-Selassie \& Simpson, 2012 (ㅁ) in the right hand column (measurements of only the M3/ are available, Haile-Selassie \& Simpson 2012).

Dasychoerus arvernensis and the Kvabebi suid have procumbent lower incisors that are positioned well beneath the level of the occlusal surface of the cheek teeth. The latter character was listed by Souron et al., (2013) as a potential synapomorphy of Kolpochoerus. Because of all this, it is concluded that Dasychoerus arvernensis and the Kvabebi suid are closely related to Kolpochoerus, Potamochoerus and Hylochoerus.

The importance of Dasychoerus arvernensis

The fossil suids from Ethiopia and Chad previously attributed to Kolpochoerus deheinzelini by Brunet \& White in 2001, are so similar to material of Dasychoerus arvernensis, that Pickford (2012) proposed that the two species were synonymous, with Dasychoerus arvernensis (Croizet \& Jobert, 1828) having priority over Kolpochoerus deheinzelini Brunet \& White, 2001. The metric analysis (Figs 16, 17) indicates how close the African and European material is, as does the morphology of the cheek teeth. The fact that the African and European fossils span the same time range strengthens the taxonomic conclusions, otherwise one would need to explain how Lower Pliocene suids from Africa and Europe which are morphometrically compatible with each other and which occurred 

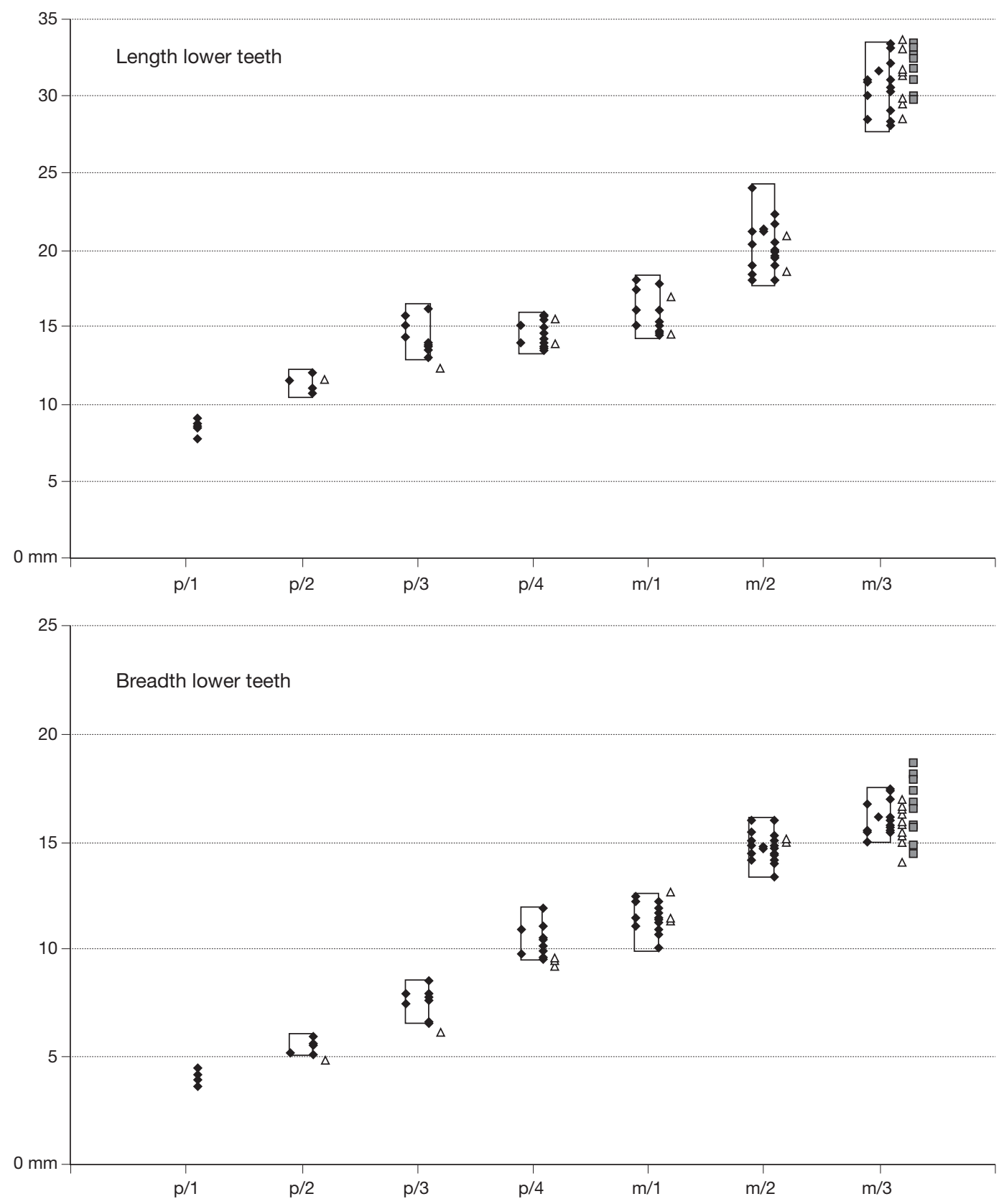

FIG. 23. - Comparison of dimensions of the lower cheek teeth of Dasychoerus arvernensis (Croizet \& Jobert, 1828) from Europe ( $\bullet$ ) and African fossils attributed to the same species (previously as Kolpochoerus deheinzelini Brunet \& White, $2001[\Delta]$ ) and the fossils attributed to Kolpochoerus millensis Haile-Selassie \& Simpson, 2012 ( $\square$ ) in the right hand column (measurements of only the $\mathrm{m} / 3$ are available, Haile-Selassie \& Simpson 2012).

as contemporaries, could belong to two distinct genera. Furthermore, such a decision would once again leave the African kolpochoeres without an ancestral group which runs against the almost universally accepted scenario that their ancestors must have dispersed into Africa from Eurasia during the basal Pliocene (Cooke \& Wilkinson 1978; Pickford 2012).

\section{BiogeOgRAPHY OF EXTANT AND EXTINCT SUIDAE} AND DISTRIBUTION OF DASYCHOERUS SPECIES

As a consequence of their high potential for demographic increase, extant suid species are capable of rapidly expand- ing their range, and the same appears to have been the case in the past. The fossil record reveals that suids were often in the vanguard of mammalian lineages dispersing to newly available territory, as for example when passage between two continents, or between continents and islands, became possible (Pickford 1993). Feral pigs have often expanded rapidly into suitable environments, even when subjected to human intervention (hunting, trapping) aimed at reducing or controlling their populations.

Today confined to Java and the Celebes (and some nearby islands [Forsyth-Major 1897]), the genus Dasychoerus was 
extremely widespread during the Pliocene, a period during which a diversity of mammals and other vertebrates spread widely over mid-latitude Eurasia which was tropical to subtropical at the time. Among the dispersals from the Far East to Europe were the tapir, the panda, the peafowl, bunodont otters, some bovids, hyaenids, giraffids, rhinocerotids, camels and monkeys, some of which managed to disperse southwards into Africa, such as some bovids, bunodont otters and other carnivores, Dasychoerus, the pea-fowl, giraffids and camels (Pickford 2012).

The poor Pliocene record in Peninsular India and the Iranian-Arabian corridor represents a void in our knowledge. A similar fossil void extends over much of Africa. Further palaeontological discoveries in these regions may fill some of the blank areas, but the overall picture that emerges is that the Far East, mid-latitude Eurasia and Africa were for a while (MN 14-MN 15: 6-3 Ma) part of a widespread tropical to subtropical biogeographic province over the extent of which dispersal by mammals was relatively easily accomplished. The high latitude limit of this palaeobiogeographic province was probably much as shown on the map (Fig. 24) (many fossil sites are known from this high latitude zone, but none have yielded Dasychoerus). Instead they contain proto-boreal taxa, including Sus sensu stricto (Sus scrofa and close relatives).

Dasychoerus has been found in Pliocene and Pleistocene deposits in Asia, Europe and Africa (Pickford 2012, 2013a, b) (Fig. 24). In Eurasia it has usually previously been identified as Sus, whereas in Africa early representatives of the genus were previously attributed to Kolpochoerus and/or Potamochoerus.

This paper recognises several species of the genus Dasychoerus in the fossil record, as well as the survival of at least two extant species, Dasychoerus verrucosus and Dasychoerus celebensis which, among extant suids, are most closely related to Euhys barbatus and more distantly related to Sus scrofa (Frantz et al. 2013).

At present Dasychoerus is restricted to the Island of Java (and small islands close to Java) (D. verrucosus) and Sulawesi (D. celebensis). However, the genus was widespread through Asia, Europe and Africa during the Pliocene and into the Pleistocene (Appendix 3). Hardjasasmita (1987) reported that Sus verrucosus is also present in Malasia and Sumatra.

The small extinct species Dasychoerus arvernensis was the most widespread member of the genus, being common in Europe, Asia and Africa. The large extinct species Dasychoerus strozzii appears to have been confined to Europe and the Middle East, although Gallai (2007) thought that it might have spread to Africa to give rise to Kolpochoerus. The extinct Pleistocene species Dasychoerus macrognathus has been reported from Java, Myanmar and China, and it could represent the ancestor of the extant species Dasychoerus verrucosus.

Fossils attributed to Dasychoerus have been reported from many localities throughout the Old World (Appendix 3).

\section{Origin of the Kolpochoerus lineage}

Wherever its ultimate centre of origin is determined to have been (the Far East? - similar species are known from Java (Hardjasasmita 1987), Myanmar (Pickford 2013b) and China (Han 1987; Pickford 2013b), as well as the Siwaliks of Indo-
Pakistan (Pickford 1988) - Dasychoerus arvernensis was in the right place (mid-latitude Eurasia) at the right time (basal Pliocene) to spread to Africa (Fig. 24) whereupon it gave rise to the Kolpochoerus and subsequently to the Hylochoerus lineage (Pickford 2013a, d) and possibly to Potamochoerus as well, an old idea (Cooke 1978; Bishop 2010), resurrected by Souron et al. (2013). The earliest record of this genus in Africa is Dasychoerus natrunensis Pickford, 2012, which either evolved into Dasychoerus arvernensis, or was replaced by a second wave of dispersal by the latter species - it did not change its generic status while entering the continent, but only later, when it was subjected to a variety of selective pressures which led to modifications in its dimensions (generally increasing in size), skull morphology (cranial dishing, expansion of the cranial table, swelling and drooping of the zygomatic arches) and dental morphology (increased hypsodonty, elongation of the third molars by addition of loph(id)s to the talon(id), hypertrophy of the canines, reduction of anterior cheek teeth).

Gallai $(2006,2007)$ postulated a slightly different scenario for the origin of Kolpochoerus, which he considered could be descended from Sus arvernensis via Sus strozzii. Whilst we agree that Kolpochoerus afarensis and Dasychoerus strozzii are related to each other and are comparable in dimensions and some details of morphology, we prefer to derive the genus Kolpochoerus earlier than is implied by the hypothesis of Gallai (2007). We estimate that the dichotomy between the Dasychoerus arvernensis-strozzii lineage on the one hand and the Dasychoerus arvernensis-Kolpochoerus lineage on the other occurred during the Pliocene $c$. 3.5 million years ago (Pickford 2012). Nevertheless, there could have been some gene flow among suid populations of Europe and Africa during the Lower Pliocene.

What the new interpretations of the fossil record reveal is that in mid-latitude Eurasia and Africa during the PlioPleistocene there was a widespread clade of suids related to the extant species Dasychoerus verrucosus which was adapted to tropical and sub-tropical regions which differed in several features from the Wild Boar (Sus scrofa and relatives) which is well adapted to boreal regions. During the Pleistocene the latter lineage populated mid-latitude regions formerly occupied by Dasychoerus species, either displacing Dasychoerus from its former more northern habitats, or simply moving in after Dasychoerus had died out in those regions consequent to climatic change (increased severity of Plio-Pleistocene cooling), with its descendants surviving only in the tropical parts of Asia, and in Africa.

\section{CONCLUSIONS}

Suid fossils from basal Pliocene deposits of Moldova provide fuel for the debate about the origin and affinities of European Dasychoerus arvernensis (Croizet \& Jobert, 1828) and African Kolpochoerus deheinzelini Brunet \& White, 2001, and related suids. It is likely that the two named taxa are synonymous (Pickford 2012). There is also a potential phylogenetic link to the the Kvabebi, Georgia, suid (Vekua 1972). 


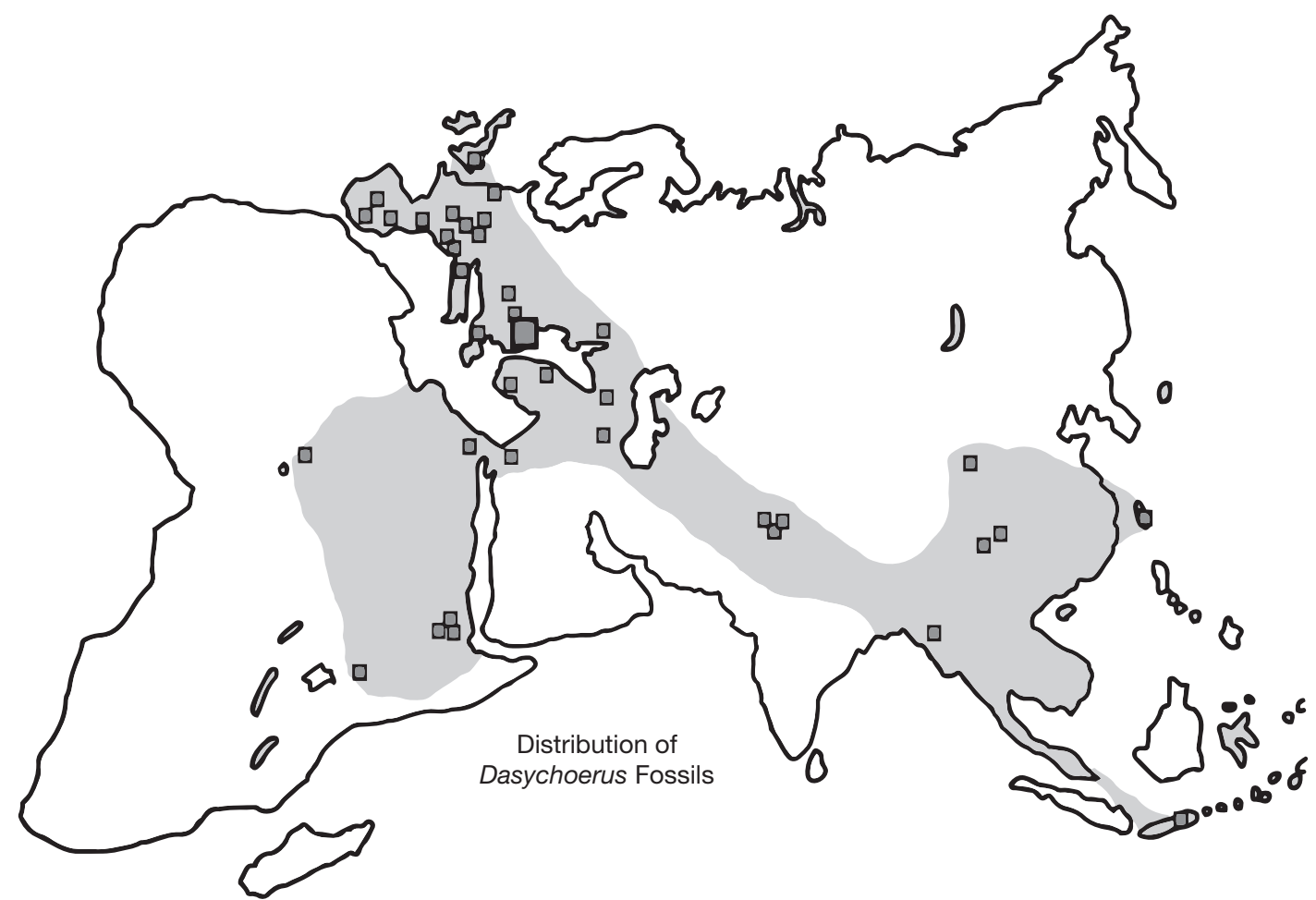

FIG. 24. - Map of the Old World showing the reconstructed Plio-Pleistocene distribution of Dasychoerus Gray, 1873 (grey zones) (fossil localities: squares). The large square west of the Black Sea localises Musaitu and Dermenji, Moldova.

The suids from Musaitu and Dermenji fit well with the correlations proposed previously (Pevzner et al. 1996, 2001; Nadachowski et al. 2006) more or less equivalent to the Ruscinian of France, - indeed, the Carbolia unit has been termed the Moldovan Ruscinian - and possibly a little earlier than the stratigraphic succession at Villafranca d'Asti in Italy that yielded Dasychoerus arvernensis. An age of c. 5-4 Ma for Musaitu would fit well with the other records of the species, not only in Europe, but also in Africa, where the same taxon has been described in Ethiopia and Chad under the name Kolpochoerus deheinzelini. In Ethiopia the range of the species is c. 5.2-3.8 Ma (Brunet \& White 2001) which coincides closely with the estimated age span of the Moldovan Mammal Complex (Pevzner et al. 1996). The Kenyan material, from the Mabaget Formation in the Tugen Hills, spans the period around $5 \mathrm{Ma}$ to $4.5 \mathrm{Ma}$ (Pickford et al. 2009). The type material of Dasychoerus arvernensis from Les Étouaires, Perrier, France is dated between 3.9 and 3.1 Ma on the basis of age determinations of lava flows beneath and above the fossiliferous deposits (Bout 1968).

The Phacochoerus lineage is more likely to have descended from a distinct ancestor, "Sus" provincialis (Blainville, 1847), via Potamochoeroides Dale, 1948, from Makapansgat and Bolt's Farm, South Africa (Bender 1992; Pickford 2012) thence to Notochoerus Broom, 1931 (Pickford 2013e) and onwards to Metridiochoerus Hopwood, 1926 (Pickford 2013a,d) and eventually to Phacochoerus Cuvier, 1826.

The similarities between the faunas from Musaitu and Dermenji on the one hand and coeval localities in south- ern Europe on the other, indicate the former presence of a widespread biogeographic province extending from Spain in the west to Moldova and Ukraine in the east, and from the shores of the Mediterranean as far north as England, Hungary and Slovakia. This region evidently had biogeographic links to Indo-Pakistan, Myanmar, Java and China, because Dasychoerus was also widespread in those regions during the Plio-Pleistocene. During the Pliocene this biogeographic province had relatively open dispersal opportunities with Africa, with evidence of several lineages of mammals dispersing from north to south (among the suids, Dasychoerus entered Africa in latest Miocene to basal Pliocene times and evolved into the Kolpochoerus and Hylochoerus lineages) and vice versa (Kolpochoerus, having originated in Africa, dispersed to the Middle East and India, and possibly as far as China during the Late Pliocene and Early Pleistocene).

\section{Acknowledgements}

The authors thank the curators in the many institutions in which they have studied fossils. Many people have contributed to the successful outcome of the long-term project on fossil suids that has been carried out over the past 35 years. All of them are thanked for providing access to fossils in their care, for providing literature and casts, and participating in discussions. Fossils studied are stored in many different museums around the world including the Natural History Museum, London, the Ipswich Museum, the Norwich Castle Museum, the British Geological Survey, Keyworth, the 
Yorkshire Museum, York, the Muséum National d'Histoire Naturelle, Paris, the Faculty of Science Museum, Université de Lyon, the CCEC Lyon, the Université de Montpellier II, Université de Toulouse, the Museo Nacional de Ciencias Naturales, Madrid, the Institut Català de Paleontolgia M. Crusafont, Sabadell, Spain, the Staatliches Museum für Naturkunde in Stuttgart (SMNS), the Bayerische Staatssammlung für Paläontologie und Geologie und Geobio-Center der Ludwig-Maximilians-Universität, München (BSPG), the Senckenberg Museum, Frankfurt, the Hessisches Landes Museum, Darmstadt, the Municipal Museum of Natural History, Mainz, and the Geologische und Palaeontologische Institut, Tübingen, Germany, the Naturhistorisches Museum, Vienna (Ursula Göhlich), the University of Vienna, the Geologische Bundesanstalt, Vienna, Austria, the Natural History Museum, Turin, the Geological Institute of the University of Florence, Italy, the University of Tbilisi, the National Museum, Tbilisi, the Georgian Academy of Science, Tbilisi, Georgia, the American Museum of Natural History, New York, Yale University (Peabody Museum), the Geological Survey of India Museum, Calcutta, the Wadia Institute of Himalayan Geology, Dehra Dun, the Saketi Fossil Park, the Punjab University, Chandigarh, the Geological Survey of India, Lucknow, the Geological Survey of Pakistan, Quetta, the Institute of Vertebrate Palaeontology and Palaeoanthropology, Beijing and the Yunnan Museum of Natural History, Youanmou, China, the National Museum of Ethnography and Natural History of Moldova, Kishinev, the Academy of Sciences of Moldova, Kishinev, and the Maden Tetkik ve Arama, Ankara, Turkey, the Orrorin Community Organisation, Kenya, and the National Museum of Kenya. Claude Guérin, Lyon, and Hiroshi Tsujikawa, Tohoku, are thanked for providing some unpublished measurements of fossils. Denis Geraads (MNHN), an anonymous referee and editors are thanked for their input to the successful outcome of this paper.

\section{REFERENCES}

AlEKSANDROVA L. P. 1989. - [Detailed stratigraphic subdivision of the Middle and Upper Pliocene deposits of South Moldavia (based on small mammals)]. Byulleten' Komissii po Izucheniyu Chetvertichnjoo Perioda, Akademiya Nauk SSSR 58: 64-81 (in Russian).

ANDREWS C. W. 1902. - Note on a Pliocene vertebrate fauna from the Wadi Natrun, Egypt. Geological Magazine NS 4, 9: 291-295, 432-439.

Arambourg C. 1947. - Mission Scientifique de l'Omo 1932-1933. Tome 1: Géologie-Anthropologie. Fascicule 3. Contribution à l'étude géologique et Paléontologique du bassin du lac Rodolphe et de la basse vallée de l'Omo. Deuxième partie: Paléontologie. Éditions du Muséum, Paris: 231-562.

ARribas A. \& GARrido G. 2008. - A new wild boar belonging to the genus Potamochoerus (Suidae, Artiodactyla, Mammalia) from the Eurasian Late Upper Pliocene (Fonelas P-1, Cuenca de Guadix, Granada), in ARRIBAs A. (ed.), Vertebrados del Plioceno superior terminal en el suroeste de Europa: Fonelas P-1 y el Proyecto Fonelas. Cuadernos del Museo Geominero 10: 337-364.

AtHANASIU S. 1912. - Fauna de Mamifere cuaternare dela Satul Draghici din Districtul Muscel. Anuarul Institut Geologic Romaniei 6: 416-440.
Athanassiou A. 1996. - Contribution to the Study of the Fossil Mammals of Thessaly, Greece. PhD Thesis, National and Kapadistrian University of Athens, Athens, 393 p.

AZZAROLI A. 1954. - Revisione della fauna dei terreni fluvio-lacustri del Valdarno Superiore, V. Filogenesi e biologia di Sus strozzii e di Sus minor. Palaeontographia italica 48: 41-76, 12 pls.

AZZAROLI A. 1975. - Remarks on the Pliocene Suidae of Europe. Zeitschrift für Säugetierkunde 40: 355-367.

Bender P. A. 1992. - A reconsideration of the fossil suid, Potamochoeroides shawi, from the Makapansgat Limeworks, Potgietersrus, Northern Transvaal. Navorsinge van die Nasionale Museum Bloemfontein 8 (1): 1-66.

BERDONDINI E. 1992. - Suids from the Early Villafranchian of Villafranca d'Asti and China. Rendiconti Lincei Scienze Fisiche e Naturali 9 (3): 109-124.

BerNSEN J. J. A. 1931. — Eine revision der fossilen säugetierfauna aus den Tonen von Tegelen, IV - Sus strozzii Meneghini. Natuurhistorische Maandblatt Maastricht, 20 ème Jaarg., 7: 104-108.

Bishop L. 2010. — Suoidea, in Werdelin L. \& SANDERS W. J. (eds), Cenozoic Mammals of Africa. Chapter 42. University of California Press, Berkeley, Los Angeles, London: 821-842.

Blainville H. M. D. DE 1847. - Ostéographie ou description iconographique comparée du squelette et du système dentaire des cinq classes d'animaux vertébrés récents et fossiles, pour servir de base à la Zoologie et à la Geologie. 4, AA, Sur les Hippopotames et les Cochons. Bertrand, Paris, 248 p., 93 pls, Atlas 4.

BoIE H. 1828. - Auszüge aus Briefen von Heinr. Boie zu Java an Hn. Schlegel, Conservator Anim. Vertebr. Am Königl. Niederl. Museum Isis von Oken, Jena, 21 (10): 1025-1035.

BolOMEY A. 1965. - Die fauna zweier villafrankischer Fundstellen in Rumaenien. Berichte der geologischen Gesellschaft der DDR, Berlin 10 (1): 77-88.

Bout P. 1960. - Le Villafranchien du Velay et du Bassin hydrographique moyen et supérieur de l'Allier. Corrélations françaises et Européens. Thèse de Doctorat (Sciences naturelles), Imprimerie Jeanne d'Arc, Le Puy-en-Velay, 344 p.

BouT P. 1968. — La limite Pliocène-Quaternaire en Europe Occidentale. Bulletin de l'Association française pour l'étude du Quaternaire 5 (1): 55-78.

Brunet M. \& White T. 2001. — Deux nouvelles espèces de Suini (Mammalia, Suidae) du continent Africain (Ethiopie, Tchad). Comptes Rendus de l'Académie des Sciences de Paris 332 (1): 51-57. http://dx.doi.org/10.1016/S1251-8050(00)01492-0

Campanino F., Forno M. G., Mottura A., Ormez-Zano D. \& SALA B. 1994. - Stephanorhinus jeanvireti (Guérin) 1972 (Rhinocerotidae, Mammalia) from Roatto near Villafranca d'Asti, NW Italy. Revision of the specimen from Dusino. Bollettino del Museo Regionale di Scienze Naturali 12 (2): 439-499.

CoOKE H. B. S. 1978. — Pliocene-Pleistocene Suidae from Hadar, Ethiopia. Kirtlandia 29: 1-63.

CoOKE H. B. S. \& Wilkinson A. 1978. — Suidae and Tayassuidae, in Maglio V. J. \& CoOKe H. B. S. (eds), Evolution of African Mammals Harvard University Press, Cambridge: 435-482.

Croizet J. B. \& JOBERT A. 1828. - Recherches sur les ossemens fossiles du département du Puy-de-Dôme. Adolphe Delahays, Paris, $226 \mathrm{p}$.

Dal PIAZ G. B. 1930. - Sopra gli avanzi di un suide scoperti nel Pliocene superiore di Bra in Piemonte. Atti della Reale Accademia delle Scienze di Torino 65: 299-303.

David A., Suspanov K., Obada T. \& Croitor R. 1997. — Evolutia teriofaunei Republicii Moldova in Pliocenul Superior - Pleistocenul Mediu. Diversitatea si ecologia lumii animale in ecosysteme naturali si antropizate. Academia de Stiinte Republicii Moldova, Institutul de Zoologie. Chisinau: 205-216.

DEPÉRET C. 1885. - Description géologique du bassin tertiaire du Roussillon. Annales des Sciences géologiques 17: 1-272.

DePÉRET C. 1890. — Les animaux pliocènes de Roussillon. Mémoires de la Société géologique de France 3: 1-164. 
DONG 2008. - Early Pleistocene suid (mammal) from the Dajushan Huainan, Anhui Province (China), Vertebrata PalAsiatica 46 (3): 233-246.

EWER R. F. 1958. - Adaptive features in the skulls of African Suidae. Proceedings of the Zoological Society of London 131: 135-155.

Ewer R. F. 1970. - The head of the Forest Hog, Hylochoerus meinertzhageni. East African Wildlife Journal 8: 43-52.

FAURE M. 2004. - Le Sus strozzii du Pliocène final de Saint-Vallier (Drôme). Geobios 37: 189, 190. http://dx.doi.org/10.1016/ S0016-6995(04)80015-9

Faure M. \& GUérin C. 1984. - Sus strozzii et Sus scrofa, deux mammifères artiodactyles, marqueurs des paléoenvironnements. Palaeogeography, Palaeoclimatology, Palaeoecology 48: 215-228.

FEJFAR O. 1961. - Die plio-pleistozänen Wirbeltierfaunen von Hajnacka und Ivanovce (Slowakei), CSR. I. Die Fundumstände und Stratigraphie. Neues Jahrbuch der Geologie und Paläontologie Abhandlungen 111 (3): 257-273.

FEJFAR O. 1964. - The lower Villafranchian vertebrates from Hajnacka, near Filakovo in Southern Slovakia. Rozpravy Ustredniho ùstavu Geologického 30: 1-117.

FORSYTH-Major C. 1881. - Studi sugli avanzi pliocenici del genere Sus (Sus strozzii Menegh.) Atti della Societa Toscana di Scienze Naturali, Processi verbali 2: 227.

Forsyth-Major C. 1897. — On Sus verrucosus Müll. \& Schleg. and allies from the Eastern Archipelago. Annals and Magazine of Natural History, Series 6, 19: 521-542.

Frantz L., Schraiber J., Madsen O., Megens H.-J., Bosse M., Paudel Y., Semiadi G., Meijaard E., Li N., Crooimans R., Archibald A., Slatkin M., Schook L., Larson G. \& GROENEN A. 2013. - Genome sequencing reveals fine scale diversification and reticulation history during speciation in Sus. Genome Biology 14 (9): 1-12. http://dx.doi.org/10.1186\%2Fgb2013-14-9-r107

Funk S., Verma S., Larson G., Prasad K., Singh L., Narayan G. \& FA J. 2007. - The pygmy hog is a unique genus: 19th Century taxonomists got it right first time round. Molecular Phylogenetics and Evolution 45: 427-436. http://dx.doi. org/10.1016/j.ympev.2007.08.007

GAAL I. vON 1943. - Unterpliozäne Säugetierreste aus Hatvan in Ungarn. Geologica Hungarica Series Palaeontologica 20: 1-120.

Gallai G. 2006. - Sistematica, Paleoecologia, Paleogeografia dei Suidae fossili italiani. Unpublished $\mathrm{PhD}$ Thesis, Università di Firenze, 201 p.

Gallai G. 2007. - Sistematica, Paleoecologia, Paleogeografia dei Suidae fossili Italiani. PaleoItalia 17: 17-22.

Gallai G. \& Rook L. 2011. — Propotamochoerus provincialis (Gervais, 1859) (Suidae, Mammalia) from the latest Miocene (Late Messinian; MN 13) of Monticino Quarry (Brisighella, Emilia-Romagna, Italy). Bollettino della Società Paleontologica Italiana 50 (1): 29-34.

Geraads D., Guérin C. \& Faure M. 1986. — Les Suidés du Pléistocène ancien d'Oubeidiyeh (Israel). Mémoires et Travaux du Centre de Recherche français de Jérusalem 5: 93-105.

Geraads D., Spassov N. \& Garevski R. 2008. - New specimens of Propotamochoerus (Suidae, Mammalia) from the Late Miocene of the Balkans. Neues Jahrbuch für Geologie und Paläontologie, Abhandlungen 248: 103-113. http://dx.doi. org/10.1127/0077-7749/2008/0248-0103

GerVAIS P. 1850. - Zoologie et Paléontologie françaises (animaux vertébrés) ou nouvelles recherches sur les animaux vivants et fossiles de la France. Arthus Bertrand, Paris, 1-3, viii p. +271 p. (1848-1852).

GERVAIS P. 1859. - Nouvelles recherches sur les animaux vertébrés dont on trouve les ossements enfouis dans le sol de la France et sur leur comparaison avec les espèces propres aux autres régions du globe. Zoologie et Paléontologie Françaises. Arthus Bertrand, Paris, 544 p.
Gliozzi E., Abbazzi L., Argenti P., Azzaroli A., Caloi L., Capasso Barbato L., Di Stefano G., Esu D., Ficcarelli G., Girotti O., Kotsakis T., Masini F., Mazza P., Mezzabota C., Palambo M. R., Petronio C., Rook L., Sala B., Sardella R., ZANALDA E. \& TORRE D. 1997. - Biochronology of selected Mammals, Molluscs and Ostracods from the Middle Pliocene to the Late Pleistocene in Italy. The state of the Art. Rivista Italiana Paleontologia Stratigrafia 35 (3): 369-388.

GolPE-PossE J.-M. 1972. — Suiformes del Terciario Español y sus yacimientos. Paleontologia y Evolucion 2: 1-197, annexes, 7 pls.

Gongora J., Cuddahee R., do Nascimento F., Palgrave C., Lowden S., Ho S., Simond D., Damayanti C., White D., Tay W., Randi E., Klingel H., Rodrigues-Zarate C., Allen K., MORAN C. \& LARSON G. 2010. - Rethinking the evolution of extant sub-Saharan African suids (Suidae, Artiodactyla). Zoologica Scripta 40 (4): 327-335. http://dx.doi.org/10.1111/j.14636409.2011.00480.x

GraY J. E. 1868. - Synopsis of the species of pigs (Suidae) in the British Museum. Proceedings of the Zoological Society of London 1868: 17-49.

Gray J. E. 1873. - Observations on Pigs (Sus, Linnaeus; Setifera, Illiger) and their skulls, with the description of a new species. Annals and Magazine of Natural History Series 4, 11: 431-439.

Gromov I. M. \& Baranova G. I. 1981. - Catalogue de Mammiferes d'URSS, (du Pliocène à l'Actuel). Institute of Zoology of the Academy of Science of the URSS «Nauka ", Leningrad, $456 \mathrm{p}$.

Groves C. 1981. - Ancestors for the pigs: taxonomy and phylogeny of the genus Sus. Technical Bulletin $N^{\circ} 3$ of the Department of Prehistory, Research School of Pacific Studies Canberra, Australian National University Press, 96 p.

Groves C. 1997. - Taxonomy of wild pigs (Sus) of the Philippines. Zoological Journal of the Linnean Society 120: 163-191.

Groves C. \& GrubB P. 1993. - The suborder Suiformes, in Oliver W. (ed.), Pigs, Peccaries, and Hippos: Status Survey and Conservation Action Plan. IUCN, Gland: 1-4.

GuÉRIN C. \& FAURE M. 1985. — Les Suidae (Mammalia, Artiodactyla) du Pliocène de la Formation de Perpignan (Roussillon) : Hommage à Charles Depéret. Paléontologie et Géologie néogènes en Roussillon: 22.

GUÉRIN C. \& TSOUKALA E. 2013. — The Tapiridae, Rhinocerotidae and Suidae (Mammalia) of the Early Villafranchian site of Milia (Grevena, Macedonia, Greece). Geodiversitas 35 (2): 447-489. http://dx.doi.org/10.5252/g2013n2a7

Guérin C., Faure M. \& SeN S. 1998. — Le gisement de vertébrés pliocènes de Çalta, Ankara, Turquie, 8. Suidae. Geodiversitas 20 (3): 441-453.

Haile-Selassie Y. \& Simpson S. 2012. - A new species of Kolpochoerus (Mammalia: Suidae) from the Pliocene of the Central Afar, Ethiopia: Its taxonomy and phylogenetic relationships. Journal of Mammalian Evolution 20 (2):115-127. http://dx.doi. org/10.1007/s10914-012-9207-0

HAN D.-F. 1987. - Artiodactyla fossils from Liucheng Gigantopithecus Cave in Guangxi. Memoirs of the Institute of Vertebrate Palaeontology and Palaeoanthropology, Academia sinica 18: 135-208.

HAN D.-F., XU C.-H. \& YI G.-Y. 1975. — Quaternary mammalian fossils from Bijiashan, Luizhou, Guangxi. Vertebrata PalAsiatica 13 (4): 250-256.

HaRdJASASMITA H. S. 1987. - Taxonomy and phylogeny of the Suidae (Mammalia) in Indonesia. Scripta geologica 85: 1-68.

HeLLMUND M. 1995. - The vertebrate locality Maramena (Macedonia, Greece) at the Turolian-Ruscinian Boundary (Neogene) 13. Suidae (Artiodactyla, Mammalia). Münchener Geowissenschaftliche Abhandlungen A 28: 143-156.

HerRe W. 1962. - Ist Sus (Porcula) salvanius Hodgson, 1847 eine Stammart vom Hausschwein? Zeitschrift für Tierzüchtung und Züchtungsbiologie 76: 265-281.

Hooljer D. A. 1947. - Notes on sme fossil mammals from the Netherlands. Archives of the Museum Teyler Séries 3, 10: 33-51. 
Hooijer D. A. 1954. - Pleistocene vertebrates from Celebes. VIII. Dentition and skeleton of Celebochoerus heekereni Hooijer. Zoologische Verhandlungen 24: 1-46.

HooijeR D. A. 1969. - Pleistocene Vertebrates from Celebes. XIII, Sus celebensis Mueller \& Schlegel, 1845. Beaufortia 222: 215-218.

Hooijer D. A. 1972. - Pleistocene Vertebrates from Celebes. XIV. Addition to the Archidiskdon-Celebochoerus fauna. Zoologische Mededelingen 46: 1-16.

HÜNERMANN K. A. 1968. — Die Suidae (Mammalia, Artiodactyla) aus den Dinotheriensanden (Unterpliozän $=$ Pont $)$ Rheinhessens (Südwestdeutschland). Schweizerische Paläontologische Abhandlungen 86: 1-96.

HüneRmann K. A. 1971. — Die Plio-Pleistozänen Wirbeltierfaunen von Hajnacka und Ivanovce (Slovakei) CSR. VII: Sus minor (Depéret, 1890). Neues Jahrbuch für Geologie und Paläontologie, Monatshefte 1971: 213-230.

HÜNERMANN K. A. 1975. - Die Suidae aus dem türkischen Neogen, in Die Gleiderung des höheren Jungtertiärs und Alt quartärs in der Turkei nach Vertebrates und ihre Bedeutung für die internationale Neogen-Stratigraphie. Geologisches Jahrbuch, B 15: 153-156.

HÜRZELER J. 1967. — Nouvelles découvertes de mammiferes dans les sédiments fluvio-lacustres de Villafranca d'Asti. Colloque International du Centre national de la Recherche scientifique 163: 633-636.

JANÒSSY D. 1986. - Pleistocene vertebrate faunas of Hungary. Developments in Paleontology and Stratigraphy. Elsevier Science Publications, Amsterdam, New York, Tokyo, 205 p.

Khomenko I. 1914. - La découverte de la Faune du Roussillon dans la Bessarabie Meridionale. Typografia Bessarabiskago Guverniskago Pravlenia, Kishinev, 10 p.

Kostopoulos D. \& Athanassiou A. 2003. - In the shadow of Plio-Pleistocene Bovidae: Suids, Cervids and Giraffids from the Greek Territory. Quaternaire hors série, 2: 179-190.

Koufos G. D. 1986. - Le presence of Sus strozzii in the Villafranchian (Villanyan) of Macedonia (Greece). Paläontologische Zeitschrift 60: 341-351.

KhubCA (KuBKHA) A. N. 1982. - [Characteristics of the Karboliya Beds and their Stratotypic Area] Kharakteristika karbolskikh sloev i ikh stratotipicheskogo raiona, in NEGADEYEV-NIKONOV K. N. (ed.), Problems of Anthropogene of Moldavia. Stiinta, Kishinev: 36-75 (in Russian).

Kullmer O., Sandrock O., Viola T. B., Hujer W., Said H. \& SEIDLER H. 2008. - Suids, elephantoids, paleochronology, and paleoecology of the Pliocene hominid site Galili, Somali region, Ethiopia. Palaios 23: 452-464. http://dx.doi.org/10.2110/ palo.2007.p07-028r

Lungu A. \& RzebiK-Kowalska B. 2011. - Faunal Assemblages, Stratigraphy and Taphonomy of the Late Miocene Localities in the Republic of Moldova. Institute of Systematics of Animals, Polish Academy of Sciences, Drukarnia Kolejowa, Krakow, 62 p.

LyDEKKER R. 1885. - Catalogue of the Fossil Mammalia in the British Museum (Natural History) Part 2, Trustees of the British Museum, London, $324 \mathrm{p}$.

LYDEKKER R. 1886. - Note on some Vertebrata from the Red Crag. Quarterly Journal of the Geological Society of London 42: 364.

LYDEKKER R. 1915. - Catalogue of Ungulate Mammals in the British Museum. Volume 4 Artiodactyla, Families Cervidae (Deer), Tragulidae (Chevrotains), Camelidae (Camels and Llamas), Suidae (Pigs and Peccaries) and Hippopotamidae (Hippopotamuses). Trustees of the British Museum (Natural History), London, 438 p.

MaCDONALD D. 2001. - The New Encyclopedia of Mammals. Oxford University Press, Oxford, $930 \mathrm{p}$.

Mazo A. V. \& Torres T. 1990. - El Pozo de Piedrabueno, un nuevo yacimientos de Vertebrados pliocenos en el Campo de Calatrava (Ciudad Real). Paleontologia i Evoluciò 23: 213-222.

MeEs G. F. 1957. — Over het belang van Temminck's « Discourse Préliminaire" voor de Zoologische nomenclatuur. Zoologische Mededelingen 35 (15): 205-227.
Montoya P., Ginsburg L., Alberdi M. T., Van der Made J., Morales J. \& Soria D. 2006. - Fossil large mammals from the Early Pliocene locality of Alcoy (Spain) and their importance in biostratigraphy. Geodiversitas 28: 137-173.

Morales J. 1984. - Venta del Moro: Su macrofauna de mamiferos y biostratigrafia continental del Mioceno terminal mediterraneo. PhD Thesis, Universidad Complutense de Madrid, 327 p., 13 pls.

MоттL M. 1939. — Die Mittelpliozäne Säugetierfauna von Gödöllő bei Budapest. Mitteilungen aus dem Jahrbuch der königliche Ungarnischen Geologischen Anstalt 32: 257-350.

MÜLLER S. 1838. - Over einige nieuwe zoogdieren van Borneo. Tijdschrift voor Naturlike Geschiedenis en Physiologie 1838-1839: 134-150.

Müller S. \& SCHLegel H. 1845. - Over die wilde zwijnen van den Indische Archipel, in TEMmincK C. J. (ed.), Verhandelingen over de natuurlijke geschiedenis der Nederlandsche Overzeesche Bezittingen, door de leden der Natuurkundige Commissie in Oost-Indië en andere schrijvers. Luchtmans \& Van den Hoek, Leiden: 169-182, pls 28-32.

Nadachowski A., Miroslaw-Grabowska J., David A., TOMEK T., Garapich A., Pascaru V. Obada T. \& Szyndlar Z. 2006. Faunal assemblages and biostratigraphy of several Pliocene sites from Moldova. Courrier Forschungsinstitut Senckenberg 256: 249-259.

NewTon E. T. 1891. - The Vertebrata of the Pliocene Deposits of Britain. Eyre \& Spottiswoode, London, 120 p.

OWEN R. 1856. - Description of some mammalian fossils from the Red Crag of Suffolk. Proceedings of the Geological Society of London 12: 186-223, figs 10-11.

Pazonyi P., Kordos L., Magyari E., Marinova E., FÜKÖH L. \& VENCZEI M. 2013. — Pleistocene vertebrate faunas of the Süttö Travertine complex (Hungary). Quaternary International 319: 50-63. http://dx.doi.org/10.1016/j.quaint.2013.02.031

PeVzner M., Vangengeim E., Vislobokova I., Sotnikova M. \& TESAKOV A. 1996. - Ruscinian of the Territory of the former Soviet Union. Newsletters in Stratigraphy 33 (2): 77-97.

Pevzner M., Vangengeim E. \& Tesakov A. 2001. - The age of the Ruscinian lower boundary. Lynx 32: 295-300.

PICKFORD M. 1988. - Revision of the Miocene Suidae of the Indian Subcontinent. Münchner Geowissenschaftliche Abhandlungen 12: 1-91.

PICKFORD M. 1993. — Old World suoid systematics, phylogeny, biogeography and biostratigraphy. Paleontologia i Evolució 26-27: 237-269.

PICKFORD M. 2012. - Ancestors of Broom's Pigs. Transactions of the Royal Society of South Africa 67: 17-35.

PICKFORD M. 2013a. - The diversity, age, biogeographic and phylogenetic relationships of Plio-Pleistocene suids from Kromdraai, South Africa. Annals of the Ditsong National Museum of Natural History 3: 1-32.

PiCKFORD M. 2013b. — Suids from the Pleistocene of Naungkwe Taung, Kayin State, Myanmar. Palaeontological Research 16 (4): 307-317. http://dx.doi.org/10.2517/1342-8144-16.4.307

PICKFORD M. 2013c. - Re-assessment of the suids from the Sables marins de Montpellier and selection of a lectotype for Sus provincialis Blainville, 1847. Geodiversitas 35 (3): 655-689. http:// dx.doi.org/10.5252/g2013n3a8

PICKFORD M. 2013d. - Locomotion, diet, body weight, origin and geochronology of Metridiochoerus andrewsi from the Gondolin karst deposits, Gauteng, South Africa. Annals of the Ditsong National Museum of Natural History 3: 33-47.

PICKFORD M. 2013e. - Reappraisal of Hylochoerus euilus Hopwood, 1926 (Suidae, Mammalia) from the Albertine Rift (Pliocene) Uganda. Geo-Pal Uganda 6: 1-26.

PickFord M., Senut B. \& Cheboi K. 2009. - The Geology and Palaeobiology of the Tugen Hills, Kenya: Rift tectonics, basin formation, volcanics and sediments. Geo-Pal Kenya 1: 4-133.

Pilgrim G. E. 1925. — Presidential address to the Geological Section of the $12^{\text {th }}$ Indian Science Congress. Proceedings of the $12^{\text {th }}$ Indian Scientific Congress: 200-218. 
Pilgrim G. E. 1926. — The Fossil Suidae of India. Memoir of the Geological Survey of India, Palaeontologica indica 8 (4): 1-65.

QI G.-Q., Ho C.-K. \& ZHANG C. 1999. - The fossil suids from the Pleistocene in Taiwan, in TONG Y.-S. (ed.), Evidence of Evolution - Essays in Honour of Prof. Chungchien Young on the Hundredth Anniversary of his Birth. China Ocean Press, Beijing: 151-164.

RADULESCU C. 2005. - Artiodactyles du Pliocène et du Pléistocène inférieur de Roumanie. Quaternaire hors série 2: 191-200.

Radulescu C., Samson P., Petculescu A. \& Stiuca E. 2003. Pliocene Large Mammals of Romania. Coloquios de Paleontologia Volume extraordinaire 1: 549-558.

RICHARZ S. 1921. - Neue Wirbeltierfunde in den Tonen von Tegelen bei Venlo. Centralblatt für Mineralogie, Geologie und Paläontologie 21: 664-669.

SAMSON P., RĂDULESCO C. \& KisgYÖRGY Z. 1971. — Nouvelles données sur la faune de Mammiferes du Villafranchien inferieur de Căpeni-Vîrghis (Depression de Brasov, Roumanie). Eiszeitalter und Gegenwart 22: 64-88.

SCHAUb S. 1943. - Die Oberpliozäne Säugetierfauna von Senèze (Haute Loire) und ihre verbreitungsgeschichtliche Stellung. Eclogae geologicae Helvetiae 36: 270-289.

SCHREUDER A. 1945. - The Tegelen Fauna, with a description of new remains of its rare components (Leptobos, Archidiskodon meridionalis, Macaca, Sus strozzii). Archives néederlandaises de Zoologie 7: 153-204.

SimionesCU I. 1930. - Vertebratele Pliocene dela Malusteni (Corvului). Academia Romana-Publicatiunile Adamachi 9 (49): 83-148.

Sisson S. \& Grossman J. 1953. - The Anatomy of the Domestic Animals. 4th Edition. W. B. Saunders, Philadelphia and London, $972 \mathrm{p}$.

SOURON A., Boisserie J.-R. \& White T. 2013. - A new species of Kolpochoerus from Ethiopia. Acta Palaeontologica Polonica 60 (1): 79-96. http://dx.doi.org/10.4202/app.2012.0083

Spassov N. 2005. - Brief review of the Pliocene ungulate fauna of Bulgaria. Quaternaire hors série 2: 201-212.

STeHLIN H. G. 1899-1900. — Über die Geschichte des Suiden Gebisses. Abhandlungen der Schweizerischen Paläontologischen Gesellschaft Zürich, 26/27: 1-527.

STEININGer F. Bernor R. \& FAHLbusCh V. 1990. — European Neogene marine/continental chronologic correlations, in LINDSAY E. H., Fahlbusch V. \& MeIN P. (eds), European Neogene Mammal Chronology. Plenum, New York and London: 15-48.

StUART A. J. 1982. - Pleistocene Vertebrates of the British Isles. Longman, London, 228 p.

SUYONO 2009. - The Study of Fossil Faunas in the Walanae Basin, Indonesia. MSc Thesis, University of Wollongong, Australia, $167 \mathrm{p}$

SYMEONIDIS N. 1992. - Lower Pleistocene (Villafranchian) fossil mammals from the Sesklo Basin (Volos). Annales géologiques des Pays helléniques 35: 1-21.

TheniUs E. 1950. — Postpotamochoerus n. subgen. hyotherioides aus dem Unterpliozän von Samos (Greichenland) und die Herkunft der Potamochoeren. Sitzungsberichten der Österreichische Akademie der Wissenschaften in Wien-Mathematisch-Naturwissenschaftliche Klasse 159 (1): 25-36.

Titov V. V. 2000. - Sus (Suidae, Mammalia) from the Upper Pliocene of the Northeastern part of the Azov Region. Paleontological Journal 34: 203-210.

Tobien H. 1936. - Mitteilungen über Wirbeltierreste aus dem Mittelpliocän des Natrontales (Ägypten) 7. Artiodactyla, A., Bunodontia. Zeitschrift der deutschen geologischen Gesellschaft 88: $42-53$
Tobien H. 1951. — Die Aufzeichnungen H. G. Stehlins über die pliozänen Säugetierreste von Herbolzheim bei Freiburg i. Br. Mitteilungsblatt der Badischen geologischen Landesanstalt, Jahrg 1950: 78-84.

Tobien H. 1952. — Die oberpliozäne Säugerfauna von Wölfersheim-Wetterau. Zeitschriften der deutschen geologischen Gesellschaft 104: 191.

TobiEn H. 1981. - Mammals of the Neogene/Quaternary boundary in the Eastern Mediterranean Area and from the Upper Siwaliks. Proceedings of Field Conference on Neogene/Quaternary Boundary (India, 1979) Calcutta: 185-197.

VAN DER MAdE J. 1988. — Sus nanus nov. sp., a Pliocene dwarf pig from Capo Figari (Northeastern Sardinia). Bolletino della Società Paleontologica Italiana 27: 367-378.

VAN DER MADE J. 1989. - European Suidae (Artiodactyla) from the Late Miocene onwards. Bolletino della Società Paleontologica Italiana 28: 329-339.

VAN DER MADE J. 1999. - Biogeography and stratigraphy of the Mio-Pleistocene mammals of Sardinia and the description of some fossils, in Reumer J. W. F. \& De Vos J. (eds), Elephants have a Snorkel! Papers in Honour of Paul Y. Sondaar - DEINSEA 7: 337-360.

VAN DER MAdE J. 2003. - Suoidea, Artiodactyla, in ForTelius M., Kappelman J., Sen S. \& Bernor R. (eds), Geology and Paleontology of the Sinap Formation, Turkey. Columbia University Press, New York: 308-327.

VAN DER MADE J. \& BelinCHON M. 1991. - Korynochoerus palaeochoerus from the Uppermost Miocene of Alcoy. Revista Española de Paleontología numero extraordinario: 173-180.

VAn der Made J. \& MoyÀ-Solà S. 1989. - European Suinae (Artiodactyla) from the Late Miocene onwards. Bolletino della Societa Palaeontolgica Italiana 28: 329-339.

Vangengeim E. A., Pevzner M. \& Tesakov A. 1995. - Chronological relationship of Pliocene deposits in fluvial plains between Prut and Southern Bug Rivers. Stratigraphy and Geological Correlation 3 (1): 54-64.

Vangengeim E. A., Pevzner M. \& Tesakov A. 2005. - Ruscinian and Lower Villafranchian: Age of boundaries and position in Magnetochronological Scale. Stratigraphy and Geological Correlation 13 (5): 530-546.

Vangengeim E. A., Vislobokova I. A. \& Sotnikova M. V. 1998. - [Large Ruscinian Mammalia in the territory of the former Soviet Union. Stratigraphy and Geological Correlation] Krupnye mlekopitayushchie Rustsiniya na Territorii Byvchego SSSR. Stratigraphy, Geology, Correlation 6 (4): 52-66 (in Russian).

Van Hoepen E. \& Van Hoepen H. 1932. - Vrijstaatse Wilde Varke. Paleontologiese Navorsing van die Nasionale Museum, Bloemfontein 2 (4): 1-23, 39-62.

VeKUA A. K. 1972. - The Akchagylian Vertebrate Fauna from Kvabebi. Nauka, Moscow, 351 p., 36 pls (in Russian).

White G. 1788. - The Natural History of Selbourne (Letter 33 to the Honourable Daines Barrington) reprinted by The Folio Society, London, 1962, $216 \mathrm{p}$.

WU G.-S., PANG J.-F. \& ZHANG Y.-P. 2006. - Molecular phylogeny and phylogeography of Suidae. Zoological Research 27: 197-201.

Young C. C. 1932 . - On the Artiodactyla from the Sinanthropus Cave at Chouk'outien, Palaeontologica sinica Series C, 8, (2): 1-158. 


\section{APPENDICES}

APPENDIX 1. - Measurements (in mm) of the teeth of Dasychoerus arvernensis (Croizet \& Jobert, 1828) from Europe. Abbreviations: B., Berdondini; G., Guérin; MDL, mesio-distal length; BLB, bucco-lingual breadth; It, left; rt, right; ms, manuscript; est., estimated; Own, refers to the author's measurements and the year of acquisition.

\begin{tabular}{|c|c|c|c|c|c|}
\hline Catalogue & Tooth & MDL & BLB & Locality, Country & Data source and comments \\
\hline NHMB VI 144 & $\mathrm{c} / 1 \mathrm{It}$ & 21.3 & 15 & Villafranca d'Asti, Italy & Own, 2012 \\
\hline NHMB VI 144 & $\mathrm{c} / 1 \mathrm{rt}$ & 21.6 & 15.4 & Villafranca d'Asti, Italy & Own, 2012 \\
\hline NHMB VI 184 & $\mathrm{c} / 1 \mathrm{rt}$ & 15.7 & 11.3 & Villafranca d'Asti, Italy & Own, 2012 \\
\hline NHMB VI 144 & C1/ It & 22 & 18 & Villafranca d'Asti, Italy & Own, 2012 \\
\hline NHMB VI 144 & $\mathrm{C} 1 / \mathrm{rt}$ & 22.6 & 17 & Villafranca d'Asti, Italy & Own, 2012 \\
\hline NHMB VI 147 & $\mathrm{Cl} / \mathrm{lt}$ & 22.3 & 17.3 & Villafranca d'Asti, Italy & Own, 2012 \\
\hline MNHN.F.PET2005 & $\mathrm{d} / 2 \mathrm{lt}$ & 8.3 & 4 & Les Étouaires, France & Own, 2011 \\
\hline MNHN.F.PET2005 & $\mathrm{d} / 2 \mathrm{rt}$ & 8.8 & 3.8 & Les Étouaires, France & Own, 2011 \\
\hline MNHN.F.PET2005 & $\mathrm{d} / 3 \mathrm{lt}$ & 10.2 & 5.6 & Les Étouaires, France & Own, 2011 \\
\hline MNHN.F.PET2005 & $\mathrm{d} / 3 \mathrm{rt}$ & 10.8 & 5.8 & Les Étouaires, France & Own, 2011 \\
\hline MNHN.F.PET2005 & $\mathrm{d} / 4 \mathrm{lt}$ & 18.8 & 10 & Les Étouaires, France & Own, 2011 \\
\hline MNHN.F.PET2005 & $\mathrm{d} / 4 \mathrm{rt}$ & 19 & 9.9 & Les Étouaires, France & Own, 2011 \\
\hline MNHN.F.PET2005 & $\mathrm{D} 2 / \mathrm{lt}$ & 10.2 & 6.7 & Les Étouaires, France & Own, 2011 \\
\hline MNHN.F.PET2005 & D3/ It & 13 & 10.2 & Les Étouaires, France & Own, 2011 \\
\hline MNHN.F.ACA313 & D4/ & 16 & 14.5 & Çalta, Turkey & Guérin et al. 1998 \\
\hline BGSK sans n Boyton & $\mathrm{D} 4 / \mathrm{It}$ & 0 & 13 & Red Crag (Boyton), England & Own, 2011 \\
\hline NHMB VI 8 & D4/ It & 14 & 13 & Villafranca d'Asti, Italy & Own, 2012 \\
\hline NHMB VI 144 & $\mathrm{i} / 1 \mathrm{lt}$ & 7.4 & 10.4 & Villafranca d'Asti, Italy & Own, 2012 \\
\hline NHMB VI 145 & $\mathrm{i} / 1 \mathrm{lt}$ & 6 & 11 & Villafranca d'Asti, Italy & Own, 2012 \\
\hline NHMB VI 144 & $\mathrm{i} / 1 \mathrm{rt}$ & 7 & 10.7 & Villafranca d'Asti, Italy & Own, 2012 \\
\hline NHMB VI 145 & $\mathrm{i} / 1 \mathrm{rt}$ & 6 & 0 & Villafranca d'Asti, Italy & Own, 2012 \\
\hline CCECL Pp 199b & $\mathrm{i} / 2$ lt & 8.7 & 12 & Perpignan, France & Own, 2011 \\
\hline BGSK sans $n^{\circ}$ Boyton & $\mathrm{i} / 2 \mathrm{lt}$ & 7.2 & 8.8 & Red Crag (Boyton), England & Own, 2011 \\
\hline NHMB VI 144 & $\mathrm{i} / 2 \mathrm{lt}$ & 7 & 11.2 & Villafranca d'Asti, Italy & Own, 2012 \\
\hline NHMB VI 145 & $\mathrm{i} / 2 \mathrm{lt}$ & 6 & 11.6 & Villafranca d'Asti, Italy & Own, 2012 \\
\hline NHMB VI 144 & $\mathrm{i} / 2 \mathrm{rt}$ & 7.6 & 12.3 & Villafranca d'Asti, Italy & Own, 2012 \\
\hline NHMB VI 145 & $\mathrm{i} / 2 \mathrm{rt}$ & 6 & 11.8 & Villafranca d'Asti, Italy & Own, 2012 \\
\hline NHMB VI 145 & $\mathrm{i} / 3 \mathrm{rt}$ & 7 & 9.4 & Villafranca d'Asti, Italy & Own, 2012 \\
\hline MNCN cast & $\mathrm{I1} / \mathrm{It}$ & 17.3 & 8.7 & Alcoy, Spain & Own, 2011 \\
\hline NHMB VI 144 & $\mathrm{I1} / \mathrm{It}$ & 10.5 & 13.7 & Villafranca d'Asti, Italy & Own, 2012 \\
\hline NHMB VI 144 & $11 / \mathrm{rt}$ & 10.9 & 13.3 & Villafranca d'Asti, Italy & Own, 2012 \\
\hline MSG P 136 & $\mathrm{p} / 1$ & 8.5 & 4.5 & Capeni, Romania & Samson et al. 1971 \\
\hline MC 12 & $\mathrm{p} / 1$ & 8.6 & 4.2 & Virghis, Romania & Samson et al. 1971 \\
\hline NHMB VI 178 & $\mathrm{p} / 1$ & 8.7 & 3.7 & Villafranca d'Asti, Italy & Own, 2012 \\
\hline MSG P 136 & $\mathrm{p} / 2$ & 12 & 6 & Capeni, Romania & Samson et al. 1971 \\
\hline NHMB VI 182 & $\mathrm{p} / 2$ lt & 10.6 & 5.7 & Villafranca d'Asti, Italy & Own, 2012 \\
\hline NHMB VI 144 & $\mathrm{p} / 2$ It & 11 & 5.1 & Villafranca d'Asti, Italy & Own, 2012; G. ms as $11 \times 5$ \\
\hline NHMB VI 145 & $\mathrm{p} / 2$ It & 11 & 5.6 & Villafranca d'Asti, Italy & Own, 2012; G. ms as $11 \times 5$ \\
\hline CCECL Pp 195 & $\mathrm{p} / 2 \mathrm{lt}$ & 11.5 & 5.2 & Perpignan, France & Own, 2011 \\
\hline FSL 41190 & $\mathrm{p} / 3 \mathrm{lt}$ & 15 & 7.5 & Perpignan, France & Own, 2011; G. ms as $14.5 \times 7.5$; FSL 41100 \\
\hline NHMB DP 8 & $\mathrm{p} / 3 \mathrm{lt}$ & 16.2 & 8.6 & Herbolzheim (cast), Germany & Own, 2012 \\
\hline NHMB VI 145 & $\mathrm{p} / 3 \mathrm{lt}$ & 13.4 & 8 & Villafranca d'Asti, Italy & Own, 2012; G. ms as $14 \times 8$ \\
\hline NHMB VI 176 & $\mathrm{p} / 3 \mathrm{lt}$ & 13.8 & 7.8 & Villafranca d'Asti, Italy & Own, 2012 \\
\hline NHMB VI 144 & $\mathrm{p} / 3$ It & 14 & 6.6 & Villafranca d'Asti, Italy & Own, 2012; G. ms as $14 \times 6.5$ \\
\hline NHMB VI 17 & $\mathrm{p} / 3 \mathrm{lt}$ & 14 & 7.7 & Villafranca d'Asti, Italy & Own, 2012 \\
\hline CCECL Pp 195 & $\mathrm{p} / 3 \mathrm{lt}$ & 14.3 & 0 & Perpignan, France & Own, 2011 ; G. ms $15 \times 7.5$ \\
\hline CCECL Pp 2601 & $\mathrm{p} / 3 \mathrm{rt}$ & 15.7 & 8 & Perpignan, France & Own, 2011; G. ms as $15 \times 8$ \\
\hline NHMB VI 145 & $\mathrm{p} / 3 \mathrm{rt}$ & 13 & 7.7 & Villafranca d'Asti, Italy & Own, 2012 \\
\hline NHMB VI 144 & $\mathrm{p} / 3 \mathrm{rt}$ & 13.7 & 6.7 & Villafranca d'Asti, Italy & Own, 2012 \\
\hline NHMB VI 172 & $\mathrm{p} / 3 \mathrm{rt}$ & 14 & 8 & Villafranca d'Asti, Italy & Own, 2012 \\
\hline Coll Aymard & $\mathrm{p} / 4$ & 15 & 11 & Perpignan, France & G. ms \\
\hline PIMUZ A/N 2347 & $\mathrm{p} / 4$ It & 14.6 & 10.5 & Dinar Akçakoy, Turkey & Own, 2014 \\
\hline NHMB VI 144 & $\mathrm{p} / 4 \mathrm{lt}$ & 13.7 & 9.6 & Villafranca d'Asti, Italy & Own, 2012; G. ms as $14 \times 9.5$ \\
\hline NHMB VI 145 & $\mathrm{p} / 4 \mathrm{lt}$ & 14 & 10.6 & Villafranca d'Asti, Italy & Own, $2012 ;$ G. $m s$ as $14.5 \times 10$ \\
\hline NHMB VI 17 & $\mathrm{p} / 4 \mathrm{lt}$ & 14.2 & 10.2 & Villafranca d'Asti, Italy & Own, 2012 \\
\hline CCECL Pp 195 & $\mathrm{p} / 4 \mathrm{lt}$ & 14 & 9.8 & Perpignan, France & Own, 2011; G. ms $14.5 \times 10$ \\
\hline MCNM & $\mathrm{p} / 4 \mathrm{rt}$ & 15.4 & 12 & Alcoy, Spain & Own, 2011 \\
\hline NHMB DP 7 & $\mathrm{p} / 4 \mathrm{rt}$ & 15.7 & 11.1 & Herbolzheim (cast), Germany & Own, 2012 \\
\hline NHMB VI 144 & $\mathrm{p} / 4 \mathrm{rt}$ & 13.4 & 9.7 & Villafranca d'Asti, Italy & Own, 2012 \\
\hline NHMB VI 145 & $\mathrm{p} / 4 \mathrm{rt}$ & 13.6 & 10.5 & Villafranca d'Asti, Italy & Own, 2012 \\
\hline NHMB VI 173 & $\mathrm{p} / 4 \mathrm{rt}$ & 14.9 & 10 & Villafranca d'Asti, Italy & Own, 2012 \\
\hline YORYM 2011.1119 & $\mathrm{p} / 4 \mathrm{rt}$ & 15.5 & 10.4 & Red Crag (Boyton), England & Own, 2011 \\
\hline YORYM 2011.1101 & $\mathrm{p} / 4 \mathrm{rt}$ & 13.8 & 10.2 & Red Crag, England & Own, 2011 \\
\hline IM 31 Walford coll. & $\mathrm{p} / 4 \mathrm{rt}$ & 14.9 & 10 & Red Crag, England & Own, 2011 \\
\hline
\end{tabular}


APPENDIX 1. - Continuation

\begin{tabular}{|c|c|c|c|c|c|}
\hline Catalogue & Tooth & MDL & BLB & Locality, Country & Data source and comments \\
\hline YORYM 2011.1105 & $\mathrm{p} / 4 \mathrm{rt}$ & 15.5 & 10 & Red Crag, England & Own, 2011 \\
\hline MCNM & $\mathrm{m} / 1 \mathrm{It}$ & 17.7 & 12.3 & Alcoy, Spain & Own, 2011 \\
\hline PIMUZ AN 2347 & $\mathrm{~m} / 1 \mathrm{lt}$ & 14.4 & 10.7 & Dinar Akçakoy, Turkey & Own, 2014 \\
\hline NHMB VI 145 & $\mathrm{~m} / 1 \mathrm{It}$ & 14.4 & 11 & Villafranca d'Asti, Italy & $\begin{array}{l}\text { Own, } 2012 \text {; G. ms as } 14.5 \times 11.5 \text {; } \\
\text { B. } 1992 \text { as } 14 \times 12\end{array}$ \\
\hline NHMB VI 144 & $\mathrm{~m} / 1 \mathrm{It}$ & 15 & 11.7 & Villafranca d'Asti, Italy & $\begin{array}{l}\text { Own, } 2012 \text {; G. ms as } 15.5 \times 11.5 \text {; } \\
\text { B. } 1992 \text { as } 14 \times 12\end{array}$ \\
\hline NHMB VI 17 & $\mathrm{~m} / 1 \mathrm{It}$ & 15 & 0 & Villafranca d'Asti, Italy & $\begin{array}{l}\text { Own, 2012; G. ms as } 14 \times 0 \text {; } \\
\text { B. } 1992 \text { as } 13 \times 12\end{array}$ \\
\hline YORYM 2011.1123 & $\mathrm{~m} / 1 \mathrm{lt}$ & 0 & 11.7 & Red Crag, England & Own, 2011 \\
\hline MNHN.F.PET2006 & $\mathrm{m} / 1 \mathrm{lt}$ & 17.4 & 12.3 & Les Étouaires, France & Own, 2011, G. ms $18 \times 13$ \\
\hline CCECL Pp 195 & $\mathrm{~m} / 1 \mathrm{lt}$ & 15.1 & 11.1 & Perpignan, France & Own, 2011; G. ms $15.5 \times 11$ \\
\hline FSL 41098 & $\mathrm{~m} / 1 \mathrm{rt}$ & 16 & 11.5 & Perpignan, France & Own, 2011; G. ms $16 \times 11$ \\
\hline MPV S/S Alcoy & $\mathrm{m} / 1 \mathrm{rt}$ & 15 & 10.1 & Alcoy, Spain (cast) & Own, 2011 \\
\hline FSL 40151 & $\mathrm{~m} / 1 \mathrm{rt}$ & 15.3 & 11.3 & Montpellier, France & Own, 2011; G. ms $15 \times 11.5$ \\
\hline NHMB VI 144 & $\mathrm{~m} / 1 \mathrm{rt}$ & 14.5 & 12 & Villafranca d'Asti, Italy & Own, 2012 \\
\hline NHMB VI 145 & $\mathrm{~m} / 1 \mathrm{rt}$ & 14.7 & 11.5 & Villafranca d'Asti, Italy & Own, 2012 \\
\hline NHMB VI 170 & $\mathrm{~m} / 1 \mathrm{rt}$ & 16 & 11.4 & Villafranca d'Asti, Italy & Own, 2012 \\
\hline BGSK sans $n^{\circ}$ Boyton & $\mathrm{m} / 1 \mathrm{rt}$ & 0 & 11.2 & Red Crag (Boyton), England & Own, 2011 \\
\hline NHMUK M 44049 & $\mathrm{~m} / 1 \mathrm{rt}$ & 15.6 & 10.9 & Red Crag, England & Own, 2011 \\
\hline YORYM 2011.1114 & $\mathrm{~m} / 1 \mathrm{rt}$ & 16.4 & 11.2 & Red Crag, England & Own, 2011 \\
\hline MNHN.F.PET2005 & $\mathrm{m} / 1 \mathrm{rt}$ & 18 & 12.5 & Les Étouaires, France & G. ms \\
\hline NHMB Rss 70 & $\mathrm{~m} / 2$ & 18 & 14.5 & Perpignan (Roussillon), France & G. ms \\
\hline Ivanovce $6513 c$ & $\mathrm{~m} / 2$ & 19.5 & 15.1 & Ivanovce, Slovakia & Hünermann, 1971 \\
\hline FSL 41097 & $\mathrm{~m} / 2$ It & 20.3 & 15.1 & Perpignan, France & Own, 2011; G. ms $20 \times 15$ \\
\hline CCECL Pp 196 & $\mathrm{~m} / 2$ It & 21.2 & 15.5 & Perpignan, France & Own, 2011; G. ms $21.5 \times 15.5$ \\
\hline NMENHM & $\mathrm{m} / 2$ It & 21.2 & 14.7 & Dermenji, Moldova & Own, 2011 \\
\hline MCNM & $\mathrm{m} / 2$ It & 20 & 14.9 & Alcoy, Spain & Own, 2011 \\
\hline PIMUZ A/V 2347 & $\mathrm{~m} / 2$ It & 19.6 & 14 & Dinar Akçakoy, Turkey & Own, 2014 \\
\hline OB 5903 & $\mathrm{~m} / 2$ It & 22.3 & 16 & Gödöllő, Hungary & Mottl 1939 as $P$. provincialis minor \\
\hline NHMB VI 17 & $\mathrm{~m} / 2 \mathrm{lt}$ & 18 & 15 & Villafranca d'Asti, Italy & $\begin{array}{l}\text { Own, } 2012 \text {; G. ms as } 18.5 \times 14.5 \text {; } \\
\text { B. } 1992 \text { as } 18 \times 17\end{array}$ \\
\hline NHMB VI 145 & $\mathrm{~m} / 2 \mathrm{lt}$ & 19.5 & 14.7 & Villafranca d'Asti, Italy & $\begin{array}{l}\text { Own, 2012; G. ms as } 19 \times 15 \text {, } \\
\text { B. } 1992 \text { as } 19 \times 15\end{array}$ \\
\hline NHMB VI 144 & $\mathrm{~m} / 2$ lt & 19.8 & 15 & Villafranca d'Asti, Italy & $\begin{array}{l}\text { Own, } 2012 \text {; G. ms as } 19 \times 15 \text {, } \\
\text { B. } 1992 \text { as } 18 \times 15\end{array}$ \\
\hline NHMUK M 5224 & $\mathrm{~m} / 2$ It & 17.8 & 13.8 & Red Crag, England & Own, 2011 \\
\hline NHMUK M 44693 & $\mathrm{~m} / 2$ It & 19.7 & 14.8 & Red Crag, England & Own, 2011 \\
\hline YORYM 2011.1104 & $\mathrm{~m} / 2$ It & 21.3 & 14 & Red Crag, England & Own, 2011 \\
\hline MNHN.F.PET2005 & $\mathrm{m} / 2$ It & 24 & 16 & Les Étouaires, France & Own, 2011 ; G. ms as $25 \times 17$ \\
\hline CCECL Pp 195 & $\mathrm{~m} / 2$ It & 18.3 & 14.2 & Perpignan, France & Own, 2011; G. ms $19 \times 14.5$ \\
\hline NHMB Perp & $\mathrm{m} / 2 \mathrm{rt}$ & 19 & 14.9 & Perpignan, France & Own, 2012 \\
\hline NMENHM & $\mathrm{m} / 2 \mathrm{rt}$ & 21.3 & 14.8 & Dermenji, Moldova & Own, 2011 \\
\hline PIMUZ A/V 2347 & $\mathrm{~m} / 2 \mathrm{rt}$ & 19.5 & 14.4 & Dinar Akçakoy, Turkey & Own, 2014 \\
\hline NHMB DP 7 & $\mathrm{~m} / 2 \mathrm{rt}$ & 21.7 & 14.2 & Herbolzheim (cast), Germany & Own, 2012 \\
\hline MIL 696 & $\mathrm{~m} / 2 \mathrm{rt}$ & 20 & 14.5 & Milia, Greece & Guérin \& Tsoukala 2013 as left \\
\hline FSL 40151 & $\mathrm{~m} / 2 \mathrm{rt}$ & 19.6 & 13.4 & Montpellier, France & Own, 2011; G. ms $21 \times 15$ \\
\hline NHMB VI 145 & $\mathrm{~m} / 2 \mathrm{rt}$ & 19 & 15.3 & Villafranca d'Asti, Italy & Own, 2012 \\
\hline NHMB VI 144 & $\mathrm{~m} / 2 \mathrm{rt}$ & 20 & 15 & Villafranca d'Asti, Italy & Own, 2012 \\
\hline NHMB VI 169 & $\mathrm{~m} / 2 \mathrm{rt}$ & 20.4 & 14.4 & Villafranca d'Asti, Italy & Own, 2012 \\
\hline NWHCM FC 2912 & $\mathrm{~m} / 2 \mathrm{rt}$ & 21 & 14.2 & Red Crag, England & Own, 2011 \\
\hline YORYM 2005.174.2.2 & $\mathrm{m} / 2 \mathrm{rt}$ & 22.7 & 16 & Red Crag, England & Own, 2011 \\
\hline NHMB Rss 70 & $\mathrm{~m} / 3$ & 30 & 15 & Perpignan (Roussillon), France & G. ms \\
\hline Coll Aymard & $\mathrm{m} / 3$ & 30.5 & 17 & Auvergne, France & G. ms \\
\hline MSG P 136 & $m / 3$ & 31 & 0 & Capeni, Romania & Samson et al. 1971 \\
\hline OB 5903 & $\mathrm{~m} / 3$ & 33.3 & 17.5 & Gödöllő, Hungary & Mottl 1939; Fejfar 1964 as $P$. provincialis minor \\
\hline Hajnacka 3983 & $\mathrm{~m} / 3$ & 33 & 17 & Hajnacka, Slovakia & Hünermann 1971 est. \\
\hline MC 12 & $\mathrm{~m} / 3$ & 32 & 16 & Virghis, Romania & Samson et al. 1971 \\
\hline CCECL Pp 196 & $\mathrm{~m} / 3$ It & 30.8 & 16.8 & Perpignan, France & Own, 2011; G. ms $31 \times 17$ \\
\hline MPV 186 ALA 4c cast & $\mathrm{m} / 3 \mathrm{It}$ & 30.2 & 15.8 & Alcoy, Spain & Own, 2011 \\
\hline PIMUZ A/V 2347 & $\mathrm{~m} / 3 \mathrm{It}$ & 0 & 15.5 & Dinar Akçakoy, Turkey & Own, 2014 \\
\hline NHMB VI 17 & $\mathrm{~m} / 3$ It & 28 & 0 & Villafranca d'Asti, Italy & $\begin{array}{l}\text { Own, 2012; G. ms as } 30.5 \times 0 \text {; } \\
\text { B. } 1992 \text { as } 27 \times 15\end{array}$ \\
\hline NHMB VI 168 & $\mathrm{~m} / 3 \mathrm{lt}$ & 28.3 & 15.5 & Villafranca d'Asti, Italy & Own, 2012; G. ms as $28.5 \times 15.5$ \\
\hline NHMB VI 144 & $\mathrm{~m} / 3$ It & 32 & 17 & Villafranca d'Asti, Italy & $\begin{array}{l}\text { Own, } 2012 ; \text { G. ms as } 30 \times 17 \text {; } \\
\text { B. } 1992 \text { as } 28 \times 16\end{array}$ \\
\hline YORYM 2005.174.1.2 & $\mathrm{m} / 3 \mathrm{lt}$ & 32.4 & 17.4 & Red Crag (Boyton), England & Own, 2011 \\
\hline YORYM 2011.1127 & $\mathrm{~m} / 3 \mathrm{It}$ & 0 & 14.4 & Red Crag, England & Own, 2011 \\
\hline IM 3 (72) & $\mathrm{m} / 3 \mathrm{lt}$ & 28.3 & 15.9 & Red Crag, England & Own, 2011 \\
\hline
\end{tabular}


APPENDIX 1. - Continuation.

\begin{tabular}{|c|c|c|c|c|c|}
\hline Catalogue & Tooth & MDL & BLB & Locality, Country & Data source and comments \\
\hline NHMUK M 9594 & $\mathrm{~m} / 3 \mathrm{It}$ & 29.1 & 15.4 & Red Crag, England & Own, 2011 ; G. ms as $29 \times 15$ \\
\hline IM 15 Walford coll. & $\mathrm{m} / 3 \mathrm{lt}$ & 30.7 & 16 & Red Crag, England & Own, 2011 \\
\hline YORYM 2011.1121 & $\mathrm{~m} / 3$ It & 30.9 & 15.5 & Red Crag, England & Own, 2011 \\
\hline NHMUK M 9149 & $\mathrm{~m} / 3$ It & 31 & 16 & Red Crag, England & Own, 2011 \\
\hline YORYM 2011.1102 & $\mathrm{~m} / 3 \mathrm{lt}$ & 32.2 & 17 & Red Crag, England & Own, 2011 \\
\hline YORYM 2005.174.1.1 & $\mathrm{m} / 3 \mathrm{It}$ & 33.9 & 17.7 & Red Crag, England & Own, 2011 \\
\hline CCECL Pp 197 & $\mathrm{~m} / 3 \mathrm{rt}$ & 28.4 & 15.5 & Perpignan, France & Own, 2011 ; G. ms $29 \times 15.5$ \\
\hline NHMB Perp & $\mathrm{m} / 3 \mathrm{rt}$ & 31 & 15.6 & Perpignan, France & Own, 2012 \\
\hline NMENHM & $\mathrm{m} / 3 \mathrm{rt}$ & 31.5 & 16.2 & Dermenji, Moldova & Own, 2011 \\
\hline MCNM & $\mathrm{m} / 3 \mathrm{rt}$ & 32 & 0 & Alcoy, Spain & Own, 2011 \\
\hline PIMUZ A/V 2347 & $\mathrm{~m} / 3 \mathrm{rt}$ & 0 & 15.6 & Dinar Akçakoy, Turkey & Own, 2014 \\
\hline FSL 40151 & $\mathrm{~m} / 3 \mathrm{rt}$ & 29 & 16.2 & Montpellier, France & Own, 2011 ; G. ms $31 \times 15.5$ \\
\hline NHMB VI 171 & $\mathrm{~m} / 3 \mathrm{rt}$ & 0 & 15.7 & Villafranca d'Asti, Italy & Own, 2012 \\
\hline NHMB VI 145 & $\mathrm{~m} / 3 \mathrm{rt}$ & 30.5 & 17.4 & Villafranca d'Asti, Italy & $\begin{array}{l}\text { Own, 2012; G. ms as } 30.5 \times 17.5 \text {; } \\
\text { B. } 1992 \text { as } 30 \times 17\end{array}$ \\
\hline NHMB VI 144 & $\mathrm{~m} / 3 \mathrm{rt}$ & 32 & 17 & Villafranca d'Asti, Italy & Own, 2012 \\
\hline BGSK 1989 & $\mathrm{~m} / 3 \mathrm{rt}$ & 0 & 14 & Red Crag (Boyton), England & Own, 2011 \\
\hline BGSK sans $n^{\circ}$ Boyton & $\mathrm{m} / 3 \mathrm{rt}$ & 0 & 15 & Red Crag (Boyton), England & Own, 2011 \\
\hline BGSK 7311 & $\mathrm{~m} / 3 \mathrm{rt}$ & 31.4 & 17.5 & $\begin{array}{l}\text { Red Crag (Waldringfield), } \\
\text { England }\end{array}$ & Own, 2011 \\
\hline $\begin{array}{l}\text { BGSK } 483574 \\
\text { XVI/5/2/48 }\end{array}$ & $\mathrm{m} / 3 \mathrm{rt}$ & 29.3 & 14.7 & $\begin{array}{l}\text { Red Crag (Woodbridge), } \\
\text { England }\end{array}$ & Own, 2011 \\
\hline NHMUK M 9148 & $\mathrm{~m} / 3 \mathrm{rt}$ & 29.7 & 16 & Red Crag, England & Own, 2011 \\
\hline NHMUK M 46574 & $\mathrm{~m} / 3 \mathrm{rt}$ & 30.6 & 15.8 & Red Crag, England & Own, 2011; G. ms as $29 \times 15$ \\
\hline NHMUK M 3782 & $\mathrm{~m} / 3 \mathrm{rt}$ & 31.4 & 16.7 & Red Crag, England & Own, 2011 ; G. ms as $31 \times 16.5$ \\
\hline FSL 40154 & $\mathrm{~m} / 3 \mathrm{rt}$ & 36.3 & 15.7 & Montpellier, France & Own, 2011; extra pair of cusps \\
\hline NHMB VI 146 & $\mathrm{P} 1 /$ It & 9.3 & 4.5 & Villafranca d'Asti, Italy & Own, 2012 \\
\hline NHMB VI 147 & $\mathrm{P} 1 /$ It & 10.7 & 4.6 & Villafranca d'Asti, Italy & Own, 2012 \\
\hline NHMB VI 21 & $\mathrm{P} 1 / \mathrm{rt}$ & 9.7 & 4.6 & Villafranca d'Asti, Italy & Own, 2012 \\
\hline NHMB VI 180 & $\mathrm{P} 1 / \mathrm{rt}$ & 9.9 & 4.3 & Villafranca d'Asti, Italy & Own, 2012 \\
\hline NHMB VI 22 & $\mathrm{P} 1 / \mathrm{rt}$ & 10.3 & 4.3 & Villafranca d'Asti, Italy & Own, 2012 \\
\hline NHMB Rss 70 & $\mathrm{P} 2 /$ & 13 & 7 & Perpignan (Roussillon), France & G. $m s$ \\
\hline PIMUZ ANV 2358 & $\mathrm{P} 2 /$ It & 12.2 & 7.3 & Afyonkarahisar, Turkey & Own, 2014 \\
\hline NMENHM & $\mathrm{P} 2 /$ It & 12.6 & 7.5 & Musaitu, Moldova & Own, 2011 \\
\hline NHMB Perp & $\mathrm{P} 2 /$ It & 12.9 & 7.9 & Perpignan, France & Own, 2012 \\
\hline CCECL Br 87 & $\mathrm{P} 2 /$ It & 13 & 7.2 & Trévoux (Reyrieux), France & Own, $2011 ;$ G. ms as $12.5 \times 7.5$ \\
\hline NHMB VI 179 & $\mathrm{P} 2 /$ It & 12 & 6.8 & Villafranca d'Asti, Italy & Own, 2012 \\
\hline NHMB VI 20 & $\mathrm{P} 2 /$ It & 12.5 & 7.7 & Villafranca d'Asti, Italy & Own, 2012 \\
\hline NHMB VI 144 & $\mathrm{P} 2 /$ It & 12.7 & 5.3 & Villafranca d'Asti, Italy & Own, 2012 \\
\hline NHMB VI 146 & $\mathrm{P} 2 /$ It & 13.2 & 8.3 & Villafranca d'Asti, Italy & Own, 2012 \\
\hline MCNM & $\mathrm{P} 2 / \mathrm{rt}$ & 13.5 & 0 & Alcoy, Spain & Own, 2011 \\
\hline NMENHM & $\mathrm{P} 2 / \mathrm{rt}$ & 12.7 & 7.7 & Musaitu Moldova & Own, 2011 \\
\hline NHMB Perp & $\mathrm{P} 2 / \mathrm{rt}$ & 13 & 7.8 & Perpignan, France & Own, 2012 \\
\hline CCECL Br 87 & $\mathrm{P} 2 / \mathrm{rt}$ & 12.7 & 7.2 & Trévoux (Reyrieux), France & Own, 2011 \\
\hline NHMB VI 144 & $\mathrm{P} 2 / \mathrm{rt}$ & 12.2 & 7.5 & Villafranca d'Asti, Italy & Own, 2012 \\
\hline NHMB VI 177 & $\mathrm{P} 2 / \mathrm{rt}$ & 12.5 & 7.5 & Villafranca d'Asti, Italy & Own, 2012 \\
\hline NHMB VI 18 & $\mathrm{P} 2 / \mathrm{rt}$ & 12.6 & 8 & Villafranca d'Asti, Italy & Own, 2012 \\
\hline NHMB VI 183 & $\mathrm{P} 2 / \mathrm{rt}$ & 12.7 & 7.2 & Villafranca d'Asti, Italy & Own, 2012 \\
\hline NHMB Rss 70 & P3/ & 14 & 11 & Perpignan (Roussillon), France & G. ms \\
\hline NMENHM & P3/ It & 13.2 & 11.4 & Musaitu, Moldova & Own, 2011 \\
\hline CCECL Pp 198 & P3/ It & 13 & 10.3 & Perpignan (Citadelle), France & Own, 2011 ; G. ms $13 \times 10.5$ \\
\hline NHMB Perp & $\mathrm{P} 3 /$ It & 13.7 & 10.5 & Perpignan, France & Own, 2012 \\
\hline CCECL Pp 200 & P3/ It & 14.7 & 10.6 & Perpignan, France & Own, 2011; G. ms as $14 \times 12$ \\
\hline Piedrabuena & P3/ It & 14 & 9.5 & Piedrabuena, Spain & Mazo \& Torres 1990 as right \\
\hline CCECL Br 87 & $\mathrm{P} 3 /$ It & 13 & 10.5 & Trévoux (Reyrieux), France & Own, $2011 ;$ G. ms as $13.5 \times 10.5$ \\
\hline NHMB VI 144 & P3/ It & 12 & 10.6 & Villafranca d'Asti, Italy & Own, $2012 ;$ G. ms as $13 \times 10.5$ \\
\hline NHMB VI 19 & P3/ It & 12.5 & 11 & Villafranca d'Asti, Italy & Own, 2012 \\
\hline NHMB VI 146 & $\mathrm{P} 3 / \mathrm{lt}$ & 12.6 & 12.6 & Villafranca d'Asti, Italy & Own, 2012; G. ms as $14 \times 12.5$ \\
\hline NHMB VI 174 & P3/ It & 12.6 & 10.6 & Villafranca d'Asti, Italy & Own, 2012 \\
\hline NHMB VI 158 & P3/ It & 13 & 11.8 & Villafranca d'Asti, Italy & Own, 2012 \\
\hline $\begin{array}{r}\text { BGSK 483566 } \\
\text { XVI/5/2/103 }\end{array}$ & P3/ It & 13 & 10 & Red Crag (Boyton), England & Own, 2011 \\
\hline YORYM 2005.173.4 & $\mathrm{P} 3 /$ It & 13.5 & 10.8 & Red Crag, England & Own, 2011 \\
\hline NMENHM & $\mathrm{P} 3 / \mathrm{rt}$ & 14 & 11.5 & Musaitu, Moldova & Own, 2011 \\
\hline NHMB Perp & P3/ rt & 13.3 & 10.8 & Perpignan, France & Own, 2012 \\
\hline CCECL Pp 198 & $\mathrm{P} 3 / \mathrm{rt}$ & 13.4 & 10 & Perpignan, France & Depéret 1885 as left (now missing) \\
\hline CCECL Br 87 & $\mathrm{P} 3 / \mathrm{rt}$ & 13.3 & 10.7 & Trévoux (Reyrieux), France & Own, 2011 \\
\hline NHMB VI 1 & P3/ rt & 12.2 & 13.3 & Villafranca d'Asti, Italy & Own, 2012; G. ms as $14 \times 13$ \\
\hline NHMB VI 161 & P3/ rt & 12.4 & 11 & Villafranca d'Asti, Italy & Own, 2012 \\
\hline NHMB VI 144 & $\mathrm{P} 3 / \mathrm{rt}$ & 13 & 10.4 & Villafranca d'Asti, Italy & Own, 2012 \\
\hline
\end{tabular}


APPENDIX 1. - Continuation

\begin{tabular}{|c|c|c|c|c|c|}
\hline Catalogue & Tooth & MDL & BLB & Locality, Country & Data source and comments \\
\hline $\begin{array}{l}\text { NHMB VI } 175 \\
\text { NHMB Rss } 62 \\
\text { NHMB Rss } 70\end{array}$ & $\begin{array}{l}\mathrm{P} 3 / \text { rt } \\
\text { P4/ } \\
\text { P4/ }\end{array}$ & $\begin{array}{l}13 \\
10.5 \\
12\end{array}$ & $\begin{array}{l}11 \\
14 \\
14\end{array}$ & $\begin{array}{l}\text { Villafranca d'Asti, Italy } \\
\text { Perpignan (Roussillon), France } \\
\text { Perpignan (Roussillon), France }\end{array}$ & $\begin{array}{l}\text { Own, } 2012 \\
\text { G. ms } \\
\text { G. ms }\end{array}$ \\
\hline NHMB VI 10 & P4/ & 12.6 & 0 & Villafranca d'Asti, Italy & Own, 2012 \\
\hline NHMB DP 6 & $\mathrm{P} 4 /$ It & 12.4 & 14.1 & Herbolzheim (cast), Germany & Own, 2012 \\
\hline NMENHM & $\mathrm{P} 4 /$ It & 11.5 & 14.5 & Musaitu, Moldova & Own, 2011 \\
\hline CCECL Pp 198 & $\mathrm{P} 4 /$ It & 12.6 & 12.5 & Perpignan (Citadelle), France & Own, 2011 ; G. ms 12.6 × 12.5 \\
\hline NHMB Perp & $\mathrm{P} 4 /$ It & 11.4 & 14.6 & Perpignan, France & Own, 2012 \\
\hline FSL 40945 & $\mathrm{P} 4 / \mathrm{It}$ & 13.6 & 14.3 & Perpignan, France & Own, 2011 ; G. ms as $13.5 \times 14$ FSL 3084 \\
\hline Piedrabuena & $\mathrm{P} 4 /$ It & 10.3 & 14 & Piedrabuena, Spain & Mazo \& Torres 1990 as right \\
\hline CCECL Br 87 & $\mathrm{P} 4 /$ It & 11 & 14.4 & Trévoux (Reyrieux), France & Own, 2011; G. ms as $11.5 \times 15$ \\
\hline NHMB VI 157 & $\mathrm{P} 4 /$ It & 11 & 14 & Villafranca d'Asti, Italy & Own, 2012 \\
\hline NHMB VI 146 & $\mathrm{P} 4 /$ It & 11.6 & 16.4 & Villafranca d'Asti, Italy & Own, $2012 ;$ G. ms as $11.5 \times 16.5$ \\
\hline NHMB VI 160 & $\mathrm{P} 4 / \mathrm{It}$ & 11.8 & 14.5 & Villafranca d'Asti, Italy & Own, 2012 \\
\hline NHMB VI 2 & $\mathrm{P} 4 /$ It & 11.9 & 15.3 & Villafranca d'Asti, Italy & Own, 2012; G. ms as $12 \times 15$ \\
\hline NHMB VI 144 & $\mathrm{P} 4 /$ It & 12 & 14.4 & Villafranca d'Asti, Italy & Own, 2012 \\
\hline NHMB VI 9 & $\mathrm{P} 4 /$ It & 12.7 & 17 & Villafranca d'Asti, Italy & Own, 2012 \\
\hline MIL 205 & $\mathrm{P} 4 / \mathrm{rt}$ & 13 & 15 & Milia, Greece & Guérin \& Tsoukala 2013 \\
\hline NMENHM & $\mathrm{P} 4 / \mathrm{rt}$ & 11.8 & 14.6 & Musaitu, Moldova & Own, 2011 \\
\hline CCECL Pp 198 & $\mathrm{P} 4 / \mathrm{rt}$ & 11 & 12.7 & Perpignan (Citadelle), France & Own, 2011 ; G. ms $11.5 \times 13$ \\
\hline NHMB Perp & $\mathrm{P} 4 / \mathrm{rt}$ & 12 & 14.6 & Perpignan, France & Own, 2012 \\
\hline NHMB RS 62 & $\mathrm{P} 4 / \mathrm{rt}$ & 12.5 & 15 & Perpignan, France & Own, 2012 ; G. ms as $12 \times 16$ \\
\hline CCECL Br 87 & $\mathrm{P} 4 / \mathrm{rt}$ & 11.6 & 14.5 & Trévoux (Reyrieux), France & Own, 2011 \\
\hline NHMB VI 144 & $\mathrm{P} 4 / \mathrm{rt}$ & 11 & 13.9 & Villafranca d'Asti, Italy & Own, 2012; G. ms as $12 \times 14$ \\
\hline NHMB VI 1 & $\mathrm{P} 4 / \mathrm{rt}$ & 11 & 16.3 & Villafranca d'Asti, Italy & Own, $2012 ;$ G. ms as $11.5 \times 16$ \\
\hline NHMB VI 159 & $\mathrm{P} 4 / \mathrm{rt}$ & 11.5 & 14.7 & Villafranca d'Asti, Italy & Own, 2012 \\
\hline NHMB VI 162 & $\mathrm{P} 4 / \mathrm{rt}$ & 12 & 14.7 & Villafranca d'Asti, Italy & Own, 2012 \\
\hline NHMB VI 3 & $\mathrm{P} 4 / \mathrm{rt}$ & 12 & 16.8 & Villafranca d'Asti, Italy & Own, 2012 \\
\hline Hajnacka 35421 & M1/ & 15.3 & 15.4 & Hajnacka, Slovakia & Hünermann 1971 \\
\hline NHMB Rss 70 & M1/ & 15 & 15.5 & Perpignan (Roussillon), France & G. ms \\
\hline NHMB Rss 62 & M1/ & 17 & 15.5 & Perpignan (Roussillon), France & G. ms \\
\hline MCNM & $\mathrm{M} 1 / \mathrm{It}$ & 16 & 15.2 & Alcoy, Spain & Own, 2011 \\
\hline NHMB DP 6 & $\mathrm{M} 1 /$ It & 0 & 14 & Herbolzheim (cast), Germany & Own, 2012 \\
\hline NMENHM & $\mathrm{M} 1 / \mathrm{It}$ & 14.2 & 15.3 & Musaitu, Moldova & Own, 2011 \\
\hline CCECL Pp 198 & $\mathrm{M} 1 /$ It & 15.3 & 14.1 & Perpignan (Citadelle), France & Own, 2011 ; G. ms $15.5 \times 14$ \\
\hline NHMB Perp & M1/ It & 16 & 14.4 & Perpignan, France & Own, 2012 \\
\hline Piedrabuena & $\mathrm{M} 1 /$ It & 14.6 & 14 & Piedrabuena, Spain & Mazo \& Torres 1990 as right \\
\hline CCECL Br 87 & $\mathrm{M} 1 /$ It & 15.6 & 15.5 & Trévoux (Reyrieux), France & $\begin{array}{l}\text { Own, } 2011 \text {; Mazo \& Torres } 1990,15.4 \times 14.8 \text {; } \\
\text { G. ms as } 15.5 \times 16\end{array}$ \\
\hline NHMB VI 2 & $\mathrm{M} 1 /$ It & 14.3 & 15.2 & Villafranca d'Asti, Italy & $\begin{array}{l}\text { Own, } 2012 ; \text { G. ms as } 13.5 \times 15.5 \\
\text { B. } 1992 \text { as } 14 \times 15\end{array}$ \\
\hline NHMB VI 144 & $\mathrm{M} 1 /$ It & 15 & 14.8 & Villafranca d'Asti, Italy & $\begin{array}{l}\text { Own, } 2012 ; \text { G. ms as } 15.5 \times 15 \text {; } \\
\text { B. } 1992 \text { as } 15 \times 14\end{array}$ \\
\hline NHMB VI 146 & $\mathrm{M} 1 /$ It & 15.8 & 16 & Villafranca d'Asti, Italy & $\begin{array}{l}\text { Own, } 2012 \text {; G. ms as } 16 \times 16 \text {; } \\
\text { B. } 1992 \text { as } 15 \times 15\end{array}$ \\
\hline NHMB VI 154 & $\mathrm{M} 1 / \mathrm{It}$ & 16 & 14.4 & Villafranca d'Asti, Italy & Own, 2012 \\
\hline YORYM 2011.1124 & $\mathrm{M} 1 /$ It & 16.3 & 13.9 & Red Crag, England & Own, 2011 \\
\hline IM 24 Walford coll. & $\mathrm{M} 1 /$ It & 17.2 & 13.4 & Red Crag, England & Own, 2011 \\
\hline MNHN.F.PET2006 & $\mathrm{M} 1 /$ It & 17.4 & 15.4 & Les Étouaires, France & Own, 2011 , G. ms as $17.5 \times 16$ \\
\hline MPV 186 ALA 46 cast & $\mathrm{M} 1 / \mathrm{rt}$ & 15 & 13.8 & Alcoy, Spain & Own, 2011 \\
\hline MIL 205 & $\mathrm{M} 1 / \mathrm{rt}$ & 18 & 15.5 & Milia, Greece & Guérin \& Tsoukala 2013 \\
\hline NMENHM & $\mathrm{M} 1 / \mathrm{rt}$ & 15.3 & 15.3 & Musaitu, Moldova & Own, 2011 \\
\hline CCECL Pp 198 & $\mathrm{M} 1 / \mathrm{rt}$ & 15.3 & 14.2 & Perpignan (Citadelle), France & $\begin{array}{l}\text { Own, 2011; G. ms } 16 \times 14 ; \\
\quad \text { Mazo \& Torres } 1990 \text { as } 15.5 \times 14.5\end{array}$ \\
\hline NHMB Perp & $\mathrm{M} 1 / \mathrm{rt}$ & 16.4 & 14.5 & Perpignan, France & Own, 2012 \\
\hline NHMB RS 62 & $\mathrm{M} 1 / \mathrm{rt}$ & 16.9 & 16.2 & Perpignan, France & Own, 2012; G. ms as $17 \times 16$ \\
\hline CCECL Br 87 & $\mathrm{M} 1 / \mathrm{rt}$ & 15.7 & 16 & Trévoux (Reyrieux), France & Own, 2011; Mazo \& Torres 1990, $16.2 \times 15$ \\
\hline NHMB VI 155 & $\mathrm{M} 1 / \mathrm{rt}$ & 14.5 & 14.9 & Villafranca d'Asti, Italy & Own, 2012 \\
\hline NHMB VI 1 & $\mathrm{M} 1 / \mathrm{rt}$ & 15.2 & 16 & Villafranca d'Asti, Italy & $\begin{array}{l}\text { Own, } 2012 \text {; G. ms as } 15 \times 16 \text {; } \\
\text { B. } 1992 \text { as } 15 \times 16\end{array}$ \\
\hline NHMB VI 144 & $\mathrm{M} 1 / \mathrm{rt}$ & 15.2 & 15 & Villafranca d'Asti, Italy & Own, 2012 \\
\hline NHMB VI 153 & $\mathrm{M} 1 / \mathrm{rt}$ & 16 & 14.4 & Villafranca d'Asti, Italy & Own, 2012 \\
\hline NHMB VI 3 & $\mathrm{M} 1 / \mathrm{rt}$ & 17 & 16.3 & Villafranca d'Asti, Italy & Own, 2012 \\
\hline YORYM 2011.1128 & $\mathrm{M} 1 / \mathrm{rt}$ & 0 & 14.4 & Red Crag, England & Own, 2011 \\
\hline NHMUK M 44695 & $\mathrm{M} 1 / \mathrm{rt}$ & 16.2 & 13.8 & Red Crag, England & Own, 2011 \\
\hline YORYM 2011.1120 & $\mathrm{M} 1 / \mathrm{rt}$ & 16.4 & 14 & Red Crag, England & Own, 2011 \\
\hline Ivanovce $6513 d$ & M2/ & 19.5 & 18.3 & Ivanovce, Slovakia & Hünermann 1971 \\
\hline NHMB Rss 107 & M2/ & 18 & 16.2 & Perpignan (Roussillon), France & Azzaroli 1954; Mazo \& Torres 1990 \\
\hline NHMB Rss 70 & M2/ & 19 & 18 & Perpignan (Roussillon), France & G. $\mathrm{ms}$ \\
\hline
\end{tabular}


APPENDIX 1. - Continuation.

\begin{tabular}{|c|c|c|c|c|c|}
\hline Catalogue & Tooth & MDL & BLB & Locality, Country & Data source and comments \\
\hline NHMB Rss fig, 2 & M2/ & 20.1 & 17.4 & Perpignan (Roussillon), France & Azzaroli 1954; Mazo \& Torres 1990 \\
\hline NHMB Rss 62 & M2/ & 20.6 & 18.5 & Perpignan (Roussillon), France & $\begin{array}{l}\text { Azzaroli 1954; Mazo \& Torres 1990; } \\
\text { G. ms as } 21 \times 18\end{array}$ \\
\hline MCNM & $\mathrm{M} 2 / \mathrm{It}$ & 19 & 17.4 & Alcoy, Spain & Own, 2011 \\
\hline MCNM & $\mathrm{M} 2 / \mathrm{lt}$ & 19.2 & 17.1 & Alcoy, Spain & Own, 2011 \\
\hline MGPUT (MB TI 449) & $\mathrm{M} 2 /$ It & 19.6 & 19.3 & Bra (Piemont), Italy & $\begin{array}{l}\text { Own, 2011; G. ms as } 20 \times 19.5 \\
\text { Dal Piaz } 1930 \text { as } 20 \times 19.4\end{array}$ \\
\hline NMENHM & $\mathrm{M} 2 / \mathrm{It}$ & 20.7 & 19.6 & Musaitu, Moldova & Own, 2011 \\
\hline CCECL Pp 198 & $\mathrm{M} 2 /$ It & 19 & 16.7 & Perpignan (Citadelle), France & $\begin{array}{l}\text { Own, 2011; G. ms } 20 \times 17 \\
\quad \text { Mazo \& Torres } 1990 \text { as } 20.5 \times 16\end{array}$ \\
\hline NHMB Perp & $\mathrm{M} 2 /$ It & 18.4 & 16.4 & Perpignan, France & Own, 2012 \\
\hline FSL 41096 & $\mathrm{M} 2 / \mathrm{It}$ & 19.2 & 17.1 & Perpignan, France & Own, 2011; G. ms as $20 \times 17.5 ;$ FSL 3058 \\
\hline FSL 40945 & $\mathrm{M} 2 / \mathrm{It}$ & 22 & 19.8 & Perpignan, France & Own, 2011 \\
\hline Piedrabuena & $\mathrm{M} 2 / \mathrm{It}$ & 19 & 17.7 & Piedrabuena, Spain & Mazo \& Torres 1990 as right \\
\hline CCECL Br 87 & $\mathrm{M} 2 /$ It & 19.5 & 18.5 & Trévoux (Reyrieux), France & $\begin{array}{l}\text { Own, 2011; Mazo \& Torres 1990, } 19.5 \times 12.9 \text {; } \\
\quad \text { G. ms as } 21.5 \times 19.5\end{array}$ \\
\hline NHMB VI 2 & $\mathrm{M} 2 /$ It & 19.4 & 17.7 & Villafranca d'Asti, Italy & $\begin{array}{l}\text { Own, } 2012 ; \text { G. ms as } 20.5 \times 18.5 \\
\text { B. } 1992 \text { as } 19 \times 18\end{array}$ \\
\hline NHMB VI 144 & $\mathrm{M} 2 / \mathrm{It}$ & 20 & 18.5 & Villafranca d'Asti, Italy & $\begin{array}{l}\text { Own, } 2012 \text {; G. ms as } 20.5 \times 18.5 \text {; } \\
\text { B. } 1992 \text { as } 19 \times 18\end{array}$ \\
\hline NHMB VI 146 & $\mathrm{M} 2 / \mathrm{It}$ & 20 & 18.5 & Villafranca d'Asti, Italy & $\begin{array}{l}\text { Own, } 2012 \text {; G. ms as } 20.5 \times 18.5 \text {; } \\
\text { B. } 1992 \text { as } 20 \times 18\end{array}$ \\
\hline NHMB VI 156 & $\mathrm{M} 2 / \mathrm{It}$ & 20.8 & 17.2 & Villafranca d'Asti, Italy & Own, 2012 \\
\hline NHMB VI 152 & $\mathrm{M} 2 / \mathrm{It}$ & 21 & 17.2 & Villafranca d'Asti, Italy & Own, 2012 \\
\hline BGSK 21716 & $\mathrm{M} 2 / \mathrm{It}$ & 19.3 & 15.4 & Red Crag (Waldringfield) England & Own, 2011 \\
\hline YORYM 2011.1111 & $\mathrm{M} 2 / \mathrm{It}$ & 21.6 & 17.8 & Red Crag (Woodbridge) England & Own, 2011 \\
\hline NHMUK M 46009 & $\mathrm{M} 2 / \mathrm{lt}$ & 18.7 & 16.1 & Red Crag, England & Own, 2011 \\
\hline NHMUK M 48961 & $\mathrm{M} 2 / \mathrm{It}$ & 19.4 & 17.2 & Red Crag, England & Own, 2011 \\
\hline YORYM 2005.174.2.3 & $\mathrm{M} 2 / \mathrm{It}$ & 19.7 & 16.6 & Red Crag, England & Own, 2011 \\
\hline NHMUK M 46691 & $\mathrm{M} 2 / \mathrm{It}$ & 20.4 & 18 & Red Crag, England & Own, 2011 \\
\hline YORYM 2011.1113 & $\mathrm{M} 2 / \mathrm{It}$ & 21 & 19 & Red Crag, England & Own, 2011 \\
\hline NHMUK M 9147 & $\mathrm{M} 2 / \mathrm{It}$ & 22.6 & 19 & Red Crag, England & Own, 2011 \\
\hline YORYM 2011.1122 & $\mathrm{M} 2 / \mathrm{It}$ & 22.7 & 17.9 & Red Crag, England & Own, 2011 \\
\hline MNHN.F.PET2006 & $\mathrm{M} 2 / \mathrm{It}$ & 19.3 & 15.5 & Les Étouaires, France & Own, 2011, G. ms as $20 \times 16$ \\
\hline MCNM & $\mathrm{M} 2 / \mathrm{rt}$ & 0 & 16.5 & Alcoy, Spain & Own, 2011 \\
\hline MCNM & $\mathrm{M} 2 / \mathrm{rt}$ & 19.5 & 16.8 & Alcoy, Spain & Own, 2011 \\
\hline MIL 205 & $\mathrm{M} 2 / \mathrm{rt}$ & 21.5 & 17.5 & Milia, Greece & Guérin \& Tsoukala 2013 \\
\hline NMENHM & $\mathrm{M} 2 / \mathrm{rt}$ & 21.1 & 19.1 & Musaitu, Moldova & Own, 2011 \\
\hline CCECL Pp 198 & $\mathrm{M} 2 / \mathrm{rt}$ & 19.8 & 16.4 & Perpignan (Citadelle), France & Own, 2011 ; G. ms $20 \times 17$ \\
\hline NHMB Perp & $\mathrm{M} 2 / \mathrm{rt}$ & 18.5 & 17 & Perpignan, France & Own, 2012 \\
\hline NHMB RS 62 & $\mathrm{M} 2 / \mathrm{rt}$ & 21.4 & 18.2 & Perpignan, France & Own, 2012; G. ms as $21 \times 19$ \\
\hline CCECL Br 87 & $\mathrm{M} 2 / \mathrm{rt}$ & 20.2 & 18.8 & Trévoux (Reyrieux), France & Own, 2011; Mazo \& Torres 1990, $19.7 \times 18.7$ \\
\hline NHMB VI 151 & $\mathrm{M} 2 / \mathrm{rt}$ & 19.6 & 17.1 & Villafranca d'Asti, Italy & Own, 2012 \\
\hline NHMB VI 144 & $\mathrm{M} 2 / \mathrm{rt}$ & 19.8 & 18 & Villafranca d'Asti, Italy & Own, 2012 \\
\hline NHMB VI 1 & $\mathrm{M} 2 / \mathrm{rt}$ & 20 & 18.3 & Villafranca d'Asti, Italy & $\begin{array}{l}\text { Own, } 2012 \text {; G. ms as } 19.5 \times 18.5 \text {; } \\
\text { B. } 1992 \text { as } 20 \times 19\end{array}$ \\
\hline NHMB VI 3 & $\mathrm{M} 2 / \mathrm{rt}$ & 22 & 20 & Villafranca d'Asti, Italy & Own, 2012 \\
\hline NHMUK M 46692 & $\mathrm{M} 2 / \mathrm{rt}$ & 20.3 & 16.7 & Red Crag, England & Own, 2011 \\
\hline YORYM 2011.1125 & $\mathrm{M} 2 / \mathrm{rt}$ & 21.7 & 17.8 & Red Crag, England & Own, 2011 \\
\hline MNHN.F.ACA314 & M3/ & 28.5 & 17 & Çalta, Turkey & Guérin et al., 1998 \\
\hline MSG P 136 & M3/ & 27.5 & 18.4 & Capeni, Romania & Samson et al. 1971 ; Mottl 1939 as $28.5 \times 19.5$ \\
\hline Hajnacka 39831 & M3/ & 25.4 & 18 & Hajnacka, Slovakia & Hünermann 1971 \\
\hline NHMB Rss 70 & M3/ & 28 & 18 & Perpignan (Roussillon), France & G. ms \\
\hline Museum Perpignan & M3/ & 0 & 17.5 & Perpignan, France & G. $m s$ \\
\hline MCNM & $\mathrm{M} 3 /$ It & 26.4 & 19.3 & Alcoy, Spain & Own, 2011 \\
\hline MCNM & $\mathrm{M} 3 / \mathrm{lt}$ & 29.4 & 18.6 & Alcoy, Spain & Own, 2011 \\
\hline MGPUT (MB TI 449) & $\mathrm{M} 3 /$ It & 27.2 & 19.5 & Bra (Piemont), Italy & $\begin{array}{l}\text { Own, 2011; G. ms as } 27.2 \times 19.15 \\
\text { Dal Piaz } 1930 \text { as } 28 \times 20\end{array}$ \\
\hline NMENHM & $\mathrm{M} 3 /$ It & 27.3 & 20.1 & Musaitu, Moldova & Own, 2011 \\
\hline CCECL Pp 198 & $\mathrm{M} 3 /$ It & 25.5 & 16.7 & Perpignan (Citadelle), France & $\begin{array}{l}\text { Own, 2011; G. ms } 26 \times 17 \\
\quad \text { Mazo \& Torres } 1990 \text { as } 25 \times 16\end{array}$ \\
\hline NHMB Perp & $\mathrm{M} 3 /$ It & 26.7 & 17.2 & Perpignan, France & Own, 2012 \\
\hline FSL 41096 & $\mathrm{M} 3 /$ It & 27 & 19.3 & Perpignan, France & Own, 2011; G. ms as $29 \times 19$; FSL 3058 \\
\hline FSL 214215 & $\mathrm{M} 3 / \mathrm{It}$ & 27.4 & 18 & Perpignan, France & Own, 2011 \\
\hline Perpignan & $\mathrm{M} 3 /$ It & 29 & 18 & Perpignan, France & Depéret 1885 \\
\hline Piedrabuena & M3/ It & 27 & 18.5 & Piedrabuena, Spain & Mazo \& Torres 1990 as right \\
\hline CCECL Br 87 & $\mathrm{M} 3 / \mathrm{It}$ & 28 & 19.6 & Trévoux (Reyrieux), France & Own, 2011; Mazo \& Torres 1990, $28.4 \times 20.1$ \\
\hline NHMB VI 4 & $\mathrm{M} 3 /$ It & 26 & 17.5 & Villafranca d'Asti, Italy & Own, 2012 \\
\hline
\end{tabular}


APPENDIX 1. - Continuation.

\begin{tabular}{|c|c|c|c|c|c|}
\hline Catalogue & Tooth & MDL & BLB & Locality, Country & Data source and comments \\
\hline NHMB VI 144 & M3/ It & 26 & 19.7 & Villafranca d'Asti, Italy & $\begin{array}{l}\text { Own, } 2012 \text {; G. ms as } 27 \times 20 \text {; } \\
\text { B. } 1992 \text { as } 26 \times 20\end{array}$ \\
\hline NHMB VI 146 & $\mathrm{M} 3 / \mathrm{It}$ & 26 & 20 & Villafranca d'Asti, Italy & Own, 2012; G. ms as $28 \times 20$ \\
\hline NHMB VI 2 & $\mathrm{M} 3 /$ It & 26 & 19.2 & Villafranca d'Asti, Italy & $\begin{array}{l}\text { Own, } 2012 ; \text { G. ms as } 25 \times 19 \text {; } \\
\text { B. } 1992 \text { as } 26 \times 19\end{array}$ \\
\hline NHMB VI 5 & $\mathrm{M} 3 /$ It & 26 & 19.7 & Villafranca d'Asti, Italy & Own, $2012 ;$ G. ms as $0 \times 19.5$ \\
\hline BGSK 7306 & $\mathrm{M} 3 /$ It & 26.7 & 18 & Red Crag (Boyton), England & Own, 2011 \\
\hline IM 23 Walford coll. & $\mathrm{M} 3 / \mathrm{It}$ & 0 & 19.7 & Red Crag, England & Own, 2011 \\
\hline IM 4 Walford coll. & $\mathrm{M} 3 / \mathrm{It}$ & 0 & 17.6 & Red Crag, England & Own, 2011 \\
\hline NWHCM FC 2912 & $\mathrm{M} 3 /$ It & 0 & 20.5 & Red Crag, England & Own, 2011 \\
\hline NHMUK M 46573 & $\mathrm{M} 3 / \mathrm{It}$ & 25.7 & 18 & Red Crag, England & Own, 2011 \\
\hline NHMUK M 3782 & $\mathrm{M} 3 / \mathrm{It}$ & 27.2 & 17.1 & Red Crag, England & Own, 2011; G. ms as $27 \times 17$ \\
\hline YORYM 2011.1103 & $\mathrm{M} 3 /$ It & 28.6 & 18.2 & Red Crag, England & Own, 2011 \\
\hline IM 1930-176-19 & $\mathrm{M} 3 / \mathrm{It}$ & 28.7 & 18 & Red Crag, England & Own, 2011 \\
\hline IM 18 Walford coll. & $\mathrm{M} 3 / \mathrm{It}$ & 30.1 & 19.8 & Red Crag, England & Own, 2011 \\
\hline MNHN.F.PET2007 & $\mathrm{M} 3 / \mathrm{It}$ & 28.5 & 0 & Les Étouaires, France & Own, 2011 , G. ms as $27.5 \times 0$ \\
\hline MCNM 700 cast & $\mathrm{M} 3 / \mathrm{rt}$ & 25.7 & 17.7 & Alcoy, Spain & Own, 2011 \\
\hline MCNM & $\mathrm{M} 3 / \mathrm{rt}$ & 29.3 & 18.4 & Alcoy, Spain & Own, 2011 \\
\hline CCECL Br 54 & $\mathrm{M} 3 / \mathrm{rt}$ & 0 & 17.5 & Autrey (Haute Savoie), France & Own, 2011 \\
\hline MIL 205 & $\mathrm{M} 3 / \mathrm{rt}$ & 29 & 17.7 & Milia, Greece & Guérin \& Tsoukala, 2013 \\
\hline NMENHM & $\mathrm{M} 3 / \mathrm{rt}$ & 27 & 20 & Musaitu, Moldova & Own, 2011 \\
\hline CCECL Pp 198 & $\mathrm{M} 3 / \mathrm{rt}$ & 25.6 & 17.6 & Perpignan (Citadelle), France & Own, 2011 ; G. ms $25 \times 17$ \\
\hline NHMB Perp & $\mathrm{M} 3 / \mathrm{rt}$ & 26.6 & 17.5 & Perpignan, France & Own, 2012 \\
\hline CCECL Br 87 & $\mathrm{M} 3 / \mathrm{rt}$ & 28.7 & 20.2 & Trévoux (Reyrieux), France & $\begin{array}{l}\text { Own, 2011; Mazo \& Torres, 1990, } 28.6 \times 19.8 \text {; } \\
\text { G. } \mathrm{ms} \text { as } 30 \times 20\end{array}$ \\
\hline NHMB VI 150 & $\mathrm{M} 3 / \mathrm{rt}$ & 25 & 17.8 & Villafranca d'Asti, Italy & Own, $2012 ;$ G. ms as $25 \times 17$ \\
\hline NHMB VI 149 & $M 3 / r t$ & 26.3 & 19.4 & Villafranca d'Asti, Italy & Own, 2012; G. ms as $27 \times 19$ \\
\hline NHMB VI 151 & $\mathrm{M} 3 / \mathrm{rt}$ & 26.4 & 18.4 & Villafranca d'Asti, Italy & Own, 2012; G. ms as $27 \times 19$ \\
\hline NHMB VI 144 & $\mathrm{M} 3 / \mathrm{rt}$ & 26.5 & 19.8 & Villafranca d'Asti, Italy & Own, 2012; G. ms as $26 \times 16.5$ \\
\hline NHMB VI 1 & $\mathrm{M} 3 / \mathrm{rt}$ & 28 & 20.4 & Villafranca d'Asti, Italy & Own, 2012; G. ms as $28 \times 21$ \\
\hline FSL 40152 & $\mathrm{M} 3 / \mathrm{rt}$ & 33 & 19.6 & Montpellier, France & Own, 2011 \\
\hline BGSK 52457 & $\mathrm{M} 3 / \mathrm{rt}$ & 28 & 0 & Red Crag (Boyton), England & Own, 2011 \\
\hline BGSK 21715 & $\mathrm{M} 3 / \mathrm{rt}$ & 0 & 18 & $\begin{array}{l}\text { Red Crag (Waldringfield), } \\
\text { England }\end{array}$ & Own, 2011 \\
\hline BGSK 21718 & $\mathrm{M} 3 / \mathrm{rt}$ & 27 & 17.6 & $\begin{array}{l}\text { Red Crag (Waldringfield), } \\
\text { England }\end{array}$ & Own, 2011 \\
\hline $\begin{array}{l}\text { BGSK } 483574 \\
\text { XVI/5/2/48 }\end{array}$ & $\mathrm{M} 3 / \mathrm{rt}$ & 26.4 & 17.3 & $\begin{array}{l}\text { Red Crag (Woodbridge), } \\
\text { England }\end{array}$ & Own, 2011 \\
\hline NHMUK M 9146 & $\mathrm{M} 3 / \mathrm{rt}$ & 24.1 & 16.4 & Red Crag, England & Own, 2011 ; G. ms as $26 \times 16.5$ \\
\hline NHMUK M 9146 & $\mathrm{M} 3 / \mathrm{rt}$ & 25.4 & 17.4 & Red Crag, England & Own, 2011; G. ms as M $9148,24.5 \times 16$ \\
\hline NHMUK M 21677 & $\mathrm{M} 3 / \mathrm{rt}$ & 27.2 & 19.4 & Red Crag, England & Own, $2011 ;$ G. ms as $27 \times 19$ \\
\hline NHMUK M 9146 & $\mathrm{M} 3 / \mathrm{rt}$ & 27.2 & 17.4 & Red Crag, England & Own, 2011 ; G. ms as $27 \times 17$ \\
\hline IM 10 Walford coll. & $M 3 / r t$ & 27.8 & 19.2 & Red Crag, England & Own, 2011 \\
\hline NWHCM FC 2912 & $\mathrm{M} 3 / \mathrm{rt}$ & 28 & 18.5 & Red Crag, England & Own, 2011 \\
\hline YORYM 2011.1126 & $\mathrm{M} 3 / \mathrm{rt}$ & 28.6 & 18.1 & Red Crag, England & Own, 2011 \\
\hline IM 1930-176-18 & $\mathrm{M} 3 / \mathrm{rt}$ & 29.1 & 18.7 & Red Crag, England & Own, 2011 \\
\hline IM 12 Walford coll. & $\mathrm{M} 3 / \mathrm{rt}$ & 29.5 & 19 & Red Crag, England & Own, 2011 \\
\hline NHMUK M 39039 & $\mathrm{M} 3 / \mathrm{rt}$ & 29.5 & 17.9 & Red Crag, England & Own, 2011; G. ms as $29 \times 18$ \\
\hline MNHN.F.PET2007 & $\mathrm{M} 3 / \mathrm{rt}$ & 28 & 18 & Les Étouaires, France & G. ms \\
\hline
\end{tabular}


APPENDIX 2. - Measurements (in mm) of the teeth of Dasychoerus arvernensis (Croizet \& Jobert, 1828) (ex Kolpochoerus deheinzelini Brunet \& White, 2001) from Africa. Abbreviations: MDL, mesio-distal length; BLB, bucco-lingual breadth; It, left; rt, right; ms, manuscript.

\begin{tabular}{|c|c|c|c|c|c|}
\hline Catalogue & Tooth & MDL & BLB & Locality, Country & Data source and comments \\
\hline NME ARA-VP 1/986 & P3/ It & 13.2 & 9.8 & Aramis, Ethiopia & Own, 2011 \\
\hline NME ARA-VP 1/986 & P3/ rt & 13.3 & 9.9 & Aramis, Ethiopia & Own, 2011 \\
\hline NME ARA-VP 1/986 & $\mathrm{P} 4 / \mathrm{lt}$ & 12.0 & 12.4 & Aramis, Ethiopia & Own, 2011 \\
\hline NME ARA-VP 1/986 & $\mathrm{M} 2 /$ It & 18.8 & 16.1 & Aramis, Ethiopia & Own, 2011 \\
\hline NME ARA-VP 1/986 & M3/ It & 24.6 & 18.6 & Aramis, Ethiopia & Own, 2011; Brunet \& White 2001, as $25,4 \times 18,6$ \\
\hline NME ARA VP 1/986 & $\mathrm{M} 3 / \mathrm{rt}$ & 25.2 & 18.2 & Aramis, Ethiopia & Brunet \& White 2001 (holotype of K. deheinzelini) \\
\hline NME URU-VP 1/10 & $\mathrm{p} / 4$ lt & 13.9 & 9.6 & Awash, Ethiopia & Own, 2011 \\
\hline NME URU-VP 1/10 & $\mathrm{m} / 2$ lt & 18.6 & 15.0 & Awash, Ethiopia & Own, 2011 \\
\hline BEL VP-1/2 & $\mathrm{m} / 3 \mathrm{lt}$ & 33.0 & 16.3 & Belohdelie, Ethiopia & Brunet \& White 2001 \\
\hline KB 3-00-001 & $\mathrm{m} / 3 \mathrm{rt}$ & 28.5 & 15.0 & Kossom Bougoudi, Chad & Brunet \& White 2001 \\
\hline KB 3-97-383 & $\mathrm{m} / 3 \mathrm{lt}$ & 29.8 & 15.5 & Kossom Bougoudi, Chad & Brunet \& White 2001 \\
\hline KB 3-97-165 & $\mathrm{m} / 3 \mathrm{rt}$ & 31.3 & 15.3 & Kossom Bougoudi, Chad & Brunet \& White 2001 \\
\hline KB 4-97-184 & $\mathrm{m} / 3 \mathrm{lt}$ & 31.5 & 16.0 & Kossom Bougoudi, Chad & Brunet \& White 2001 \\
\hline KB 7-98-007 & $\mathrm{m} / 3 \mathrm{rt}$ & 33.0 & 16.6 & Kossom Bougoudi, Chad & Brunet \& White 2001 \\
\hline KB 4-97-185 & $\mathrm{M} 3 / \mathrm{rt}$ & 25.5 & 17.0 & Kossom Bougoudi, Chad & Brunet \& White 2001 \\
\hline KB 3-98-066 & $\mathrm{M} 3 / \mathrm{rt}$ & 27.3 & 16.6 & Kossom Bougoudi, Chad & Brunet \& White 2001 \\
\hline KNM BC 1462 & $\mathrm{M} 3 / \mathrm{rt}$ & 28.0 & 18.6 & KNM BC 1462 & Tsujikawa, ms \\
\hline OCO Bar 2074'05 & $\mathrm{p} / 4$ & 13.9 & 9.3 & OCO Bar 2074'05 & Own, 2005 \\
\hline OCO Bar 2074'05 & $\mathrm{m} / 1 \mathrm{lt}$ & 0 & 11.5 & OCO Bar 2074'05 & Pickford et al. 2009 \\
\hline OCO 842'11 & $\mathrm{m} / 1 \mathrm{lt}$ & 17.0 & 12.7 & OCO 842'11 & Own, 2011 \\
\hline OCO Bar 2074'05 & $\mathrm{m} / 2$ lt & 20.9 & 15.2 & OCO Bar 2074’05 & Pickford et al. 2009 \\
\hline OCO Bar 2074’05 & $\mathrm{m} / 3 \mathrm{lt}$ & 31.6 & 15.9 & OCO Bar 2074’05 & Pickford et al. 2009 \\
\hline OCO 841'11 & $\mathrm{m} / 3 \mathrm{rt}$ & 33.6 & 16.7 & OCO 841'11 & Own, 2011 \\
\hline OCO Bar 4'06 & $\mathrm{M} 3 / \mathrm{rt}$ & 30.0 & 19.1 & OCO Bar 4’06 & Own, 2006 \\
\hline OCO Bar 1353’05 & $\mathrm{p} / 2 \mathrm{rt}$ & 11.6 & 4.9 & OCO Bar 1353’05 & Own, 2005 \\
\hline OCO Bar 1352'05 & $\mathrm{P} 2 / \mathrm{rt}$ & 11.8 & 6.5 & OCO Bar 1352’05 & Own, 2005 \\
\hline OCO Bar 59’05 & M3/ It & 26.5 & 19.3 & OCO Bar 59’05 & Own, 2005 \\
\hline OCO Bar 853’05 & D4/ rt & 0 & 11.8 & OCO Bar 853’05 & Own, 2005 \\
\hline OCO 1523'11 & P2/ It & 11.7 & 7.0 & OCO 1523'11 & Own, 2011 \\
\hline OCO 126’11 & $\mathrm{p} / 3 \mathrm{lt}$ & 12.3 & 6.2 & OCO 126'11 & Own, 2011 \\
\hline OCO 206'11 & $\mathrm{p} / 4$ It & 15.5 & 9.7 & OCO 206'11 & Own, 2011 \\
\hline OCO 1522'11 & $\mathrm{m} / 3$ & 0 & 15.3 & OCO 1522'11 & Own, 2011 \\
\hline OCO 1407'11 & $\mathrm{m} / 3 \mathrm{rt}$ & 29.5 & 14.1 & OCO $1407 ' 11$ & Own, 2011 \\
\hline OCO 125'11 & I3/ It & 6.2 & 4.4 & OCO 125'11 & Own, 2011 \\
\hline OCO Bar 1060’05 & $\mathrm{P} 4 /$ It & 12.3 & 12.3 & OCO Bar 1060’05 & Own, 2005 \\
\hline
\end{tabular}


APPENDIX 3. - Distribution of extinct species of Dasychoerus Gray, 1873 and other Plio-Pleistocene suids of mid-latitude Eurasia arranged by taxon and country.

\begin{tabular}{|c|c|c|}
\hline Taxon & Country & Localities and references \\
\hline \multirow[t]{18}{*}{$\begin{array}{l}\text { Dasychoerus arvernensis } \\
\quad \text { (Croizet \& Jobert, 1828) }\end{array}$} & France & $\begin{array}{l}\text { Perrier les Étouaires (type locality, Croizet \& Jobert 1828; Bout 1960; } \\
\quad \text { Pickford 2012); } \\
\text { Cavaillé Brickyard (Perpignan, Serrat d’En Vacquer, Depéret 1890; } \\
\quad \text { Azzaroli 1954); } \\
\text { Mas Bruno (St Estève, Guérin et al. 1998); } \\
\text { Autrey (near Gray, Haute Saône, Depéret 1890; this paper); } \\
\text { Vialette (Guérin et al. 1998); } \\
\text { Trévoux-Reyrieux (Guérin et al. 1998); } \\
\text { Sables marins de Montpellier (Pickford 2013c). }\end{array}$ \\
\hline & Spain & $\begin{array}{l}\text { Gorafe IV (Van der Made 1989); } \\
\text { Piedrabuena (Mazo \& Torres 1990); } \\
\text { Alcoy (Golpe-Posse } 1972 \text {; Van der Made \& Belinchon 1991; Montoya } \\
\text { et al. 2006). }\end{array}$ \\
\hline & England & Red Crag (Lydekker 1885, 1886; Newton 1891; Guérin et al. 1998). \\
\hline & Germany & $\begin{array}{l}\text { Herbolzheim (Tobien 1951); } \\
\text { Wölfersheim-Wetterau (Tobien 1952). }\end{array}$ \\
\hline & Italy & $\begin{array}{l}\text { Val di Pugna (Berdondini 1992; Gallai 2006); } \\
\text { Barga, Pieve Fosciana, Triversa, Bra (Dal Piaz 1930); } \\
\text { Villafranca d'Asti (Azzaroli 1954; Hürzeler 1967; Berdondini 1992); } \\
\text { Collepardo (Anagni Basin, Gliozzi et al. 1997; Guérin \& Tsoukala 2013); } \\
\text { Roallo (Campanino et al. 1994; Guérin \& Tsoukala 2013). }\end{array}$ \\
\hline & Slovakia & $\begin{array}{l}\text { Hajnacka (Fejfar 1961, 1964; Hünermann 1971); } \\
\text { Ivanovce (Fejfar 1961; Hünermann 1971). }\end{array}$ \\
\hline & Hungary & Gödöllő (Mottl 1939; Fejfar 1964). \\
\hline & Romania & $\begin{array}{l}\text { Baraolt Basin (Barot-Köpec); } \\
\text { Capeni (Mottl 1939; Radulescu et al. 2003; Radulescu 2005); } \\
\text { Virghis (Radulescu et al. 2003; Radulescu 2005) }\end{array}$ \\
\hline & Moldova & $\begin{array}{l}\text { Musaitu, Dermenji (this paper, Moldovian Faunal Complex, David } \\
\text { et al. 1997) }\end{array}$ \\
\hline & Bulgaria & Mussielevo (Spassov 2005) \\
\hline & Greece & $\begin{array}{l}\text { Milia (Guérin \& Tsoukala 2013); } \\
\text { Damatria? (Rhodes, Koufos 1986); } \\
\text { Megalo Emvolon (Radulescu et al. 2003); } \\
\text { Sesklo (Symeonidis 1992; Athanassiou 1996; Kostopoulos \& } \\
\quad \text { Athanassiou 2003). }\end{array}$ \\
\hline & Turkey & $\begin{array}{l}\text { Afyon Dinar Akçakoy (Hünermann 1975); } \\
\text { Çalta (Guérin et al. 1998); } \\
\text { Afyon Karahisar (Sandiki-Garkin area, this paper). }\end{array}$ \\
\hline & Ethiopia & $\begin{array}{l}\text { Aramis (Kolpochoerus deheinzelini, Brunet \& White 2001); } \\
\text { Belohdelie (Brunet \& White 2001); } \\
\text { Sagantole (Brunet \& White 2001); } \\
\text { Galili (Kullmer et al. 2008; Haile-Selassie \& Simpson 2012). }\end{array}$ \\
\hline & Chad & Kossom Bougoudi (Kolpochoerus deheinzelini, Brunet \& White 2001). \\
\hline & Kenya & Mabaget Formation (Tugen Hills, Pickford et al. 2009; this paper). \\
\hline & India & $\begin{array}{l}\text { Siwalik Hills (many of the specimens attributed to Sus hysudricus } \\
\text { Falconer \& Cautley, 1846, belong to this species not to be confused with } \\
\text { Propotamochoerus hysudricus [Stehlin 1899-1900; Pilgrim 1925, 1926)]. }\end{array}$ \\
\hline & China & Nanzhuanggou (Shanxi, Berdondini 1992). \\
\hline & Taiwan & Qiding (Sus houi, Qi et al. 1999). \\
\hline $\begin{array}{l}\text { Non Dasychorus arvernensis } \\
\quad(=\text { Hippopotamodon major })\end{array}$ & Greece & Servia (Tobien 1981). \\
\hline Dasychoerus natrunensis Pickford, 2012 & Egypt & Wadi Natrun, Egypt (Andrews 1902; Tobien 1936; Pickford 2012). \\
\hline \multirow[t]{2}{*}{$\begin{array}{l}\text { Dasychoerus nanus (sondaari) } \\
\text { (Van der Made, 1988) }\end{array}$} & Italy & $\begin{array}{l}\text { Capo Mannu (Capo Figari, Sardinia, Van der Made 1988, 1999; Gallai } \\
\text { 2006, 2007). }\end{array}$ \\
\hline & Ethiopia & Omo (Kolpochoerus cookei, Brunet \& White 2001; Pickford 2012). \\
\hline $\begin{array}{l}\text { Dasychoerus macrognathus } \\
\text { (Dubois, 1908) }\end{array}$ & Java & $\begin{array}{l}\text { Kedungbrubus, Bangle, Ngandong (Sus terhaari); } \\
\text { Bumiayu (Sus stremmi); } \\
\text { Sumberkepuh, Kebonduren, Teguan (Hardjasasmita 1987). }\end{array}$ \\
\hline
\end{tabular}


APPENDIX 3. - Continuation.

\begin{tabular}{|c|c|c|}
\hline Taxon & Country & Localities and references \\
\hline \multirow{3}{*}{$\begin{array}{l}\text { Dasychoerus macrognathus } \\
\text { (Dubois, 1908) }\end{array}$} & Myanmar & Naungkwe Taung (Pickford 2013b) \\
\hline & China & $\begin{array}{l}\text { Liucheng Gigantopithecus Cave (Sus australis, Han 1987); } \\
\text { Bijiashan Cave (Han et al. 1975). }\end{array}$ \\
\hline & Taiwan & Qiding (Qi et al. 1999). \\
\hline $\begin{array}{l}\text { Dasychoerus brachygnathus } \\
\text { (Dubois, 1908) }\end{array}$ & Java & $\begin{array}{l}\text { Trinil, Kebonduren, Bangle, Kaligede, Teguan, Watualang (Sus } \\
\text { vatualangensis) (Hardjasasmita 1987). }\end{array}$ \\
\hline \multirow[t]{12}{*}{$\begin{array}{l}\text { Dasychoerus strozzii } \\
\text { (Meneghini, 1862) }\end{array}$} & Italy & $\begin{array}{l}\text { Val d'Arno (Forsyth-Major 1881; Azzaroli 1954, 1975); } \\
\text { Olivola (Azzaroli 1954, 1975); } \\
\text { Brisighella (Gallai \& Rook 2011); } \\
\text { Quercia (Azzaroli 1954); } \\
\text { Casino (Stehlin 1899-1900; this paper); } \\
\text { Mugello (Faure \& Guérin 1984). }\end{array}$ \\
\hline & France & $\begin{array}{l}\text { Montpellier (Sables marins de Montpellier, a composite unit, Fejfar } \\
\quad \text { 1964; Pickford 2013c); } \\
\text { Senèze (Schaub 1943; Azzaroli 1954, 1975); } \\
\text { Le Coupet? (Geraads et al. 1986; Faure 2004); } \\
\text { Saint-Vallier (Faure 2004). }\end{array}$ \\
\hline & Spain & $\begin{array}{l}\text { Fonelas (Potamochoerus magnus, Arribas \& Garrido 2008); } \\
\text { Valdeganga (Van der Made \& Moyà-Solà 1989). }\end{array}$ \\
\hline & England & $\begin{array}{l}\text { Red Crag (Owen 1856; Lydekker 1885, 1886; Newton } 1891 \text { (Nodule } \\
\text { Bed); Stuart 1982; Guérin et al. 1998). }\end{array}$ \\
\hline & Holland & $\begin{array}{l}\text { Tegelen (Richarz 1921; Bernsen 1931; Schreuder 1945; Hooijer 1947; } \\
\text { Van der Made \& Moyà-Solà 1989). }\end{array}$ \\
\hline & Greece & $\begin{array}{l}\text { Gerakarou (Kostopoulos \& Athanassiou 2003); } \\
\text { Vassiloudi (Kostopoulos \& Athanassiou 2003; Koufos 1986). }\end{array}$ \\
\hline & Romania & Valea Graunceanului (Tetoiu) (Bolomey 1965; Faure 2004). \\
\hline & Moldova & Khaprovian and Odessian Faunal Complexes (David et al. 1997). \\
\hline & Russia & Khapry (Titov 2000). \\
\hline & North Caucasus & $\begin{array}{l}\text { Tamansk? (Sus tamanensis, Gromov \& Baranova 1981; Geraads et al. } \\
\text { 1986). }\end{array}$ \\
\hline & Azerbaijan & Palan-Tyukan (Titov 2000; Kostopoulos \& Athanassiou 2003). \\
\hline & Israel & Oubeidiyeh (Geraads et al. 1986; Kostopoulos \& Athanassiou 2003). \\
\hline \multirow{2}{*}{$\begin{array}{l}\text { Dasychoerus sp. } \\
\text { from Kvabebi }\end{array}$} & Georgia & Kvabebi (Vekua 1972). \\
\hline & Spain & ?Corral de Lobato (this paper). \\
\hline \multirow{5}{*}{$\begin{array}{l}\text { Suidae incertae sedis } \\
\text { (taxon to which the Samos } \\
\text { specimen attributed to } \\
\text { Postpotamochoerus "hyotherioides" } \\
\text { by Thenius 1950, belongs) }\end{array}$} & Moldova & Nikolskoe (Titov 2000, this paper). \\
\hline & Macedonia & Kalnitsa (Geraads et al. 2008), Vozarci (Geraads et al. 2008). \\
\hline & Bulgaria & Kalimantsi (Geraads et al. 2008). \\
\hline & Greece & Maramena (Hellmund 1995; Geraads et al. 2008), Samos (Thenius 1950). \\
\hline & England & Red Crag (Pickford 2013c). \\
\hline \multirow[t]{8}{*}{$\begin{array}{l}\text { Potamochoerus provincialis } \\
\text { (Blainville, 1847) }\end{array}$} & France & $\begin{array}{l}\text { Montpellier (Sables marins de Montpellier; Blainville 1847; Gervais } \\
\text { 1850, 1859; Fejfar 1964; Pickford 2013c); }\end{array}$ \\
\hline & Spain & Venta del Moro (Morales 1984); \\
\hline & Italy & Casino (Gallai 2006), Brisighella (Gallai 2006); \\
\hline & Romania & Malusteni (Athanasiu 1912 ; Simionescu 1930) \\
\hline & Moldova & $\begin{array}{l}\text { Carbolia Formation (Karboliya Beds of Pevzner et al. 1996) \{Lucesti } \\
\text { (Vangengeim et al. 1998); Pelinei (David et al. 1997)\}= Moldovian } \\
\text { Faunal Complex (David et al. 1997). }\end{array}$ \\
\hline & Hungary & $\begin{array}{l}\text { Hatvan (Gaal 1943; Hünermann } 1975 \text {, identified the suid lower molar as } \\
\text { Sus minor, but the tooth is too large to belong to this species, being } \\
\text { compatible in dimensions to Potamochoerus provincialis from Montpellier) }\end{array}$ \\
\hline & Russia & Kosiakino (Vangengeim et al. 1998). \\
\hline & Turkey & Sinap Tepe 42 (Van der Made 2003). \\
\hline $\begin{array}{l}\text { Specimen of Sus scrofa } \\
\text { Linnaeus, } 1758, \text { previously } \\
\text { identified as Sus arvernensis }\end{array}$ & Hungary & $\begin{array}{l}\text { Süttö (Janössy 1986; Guérin \& Tsoukala 2013; = Sus scrofa according } \\
\text { to Pazonyi et al. 2013). }\end{array}$ \\
\hline
\end{tabular}

